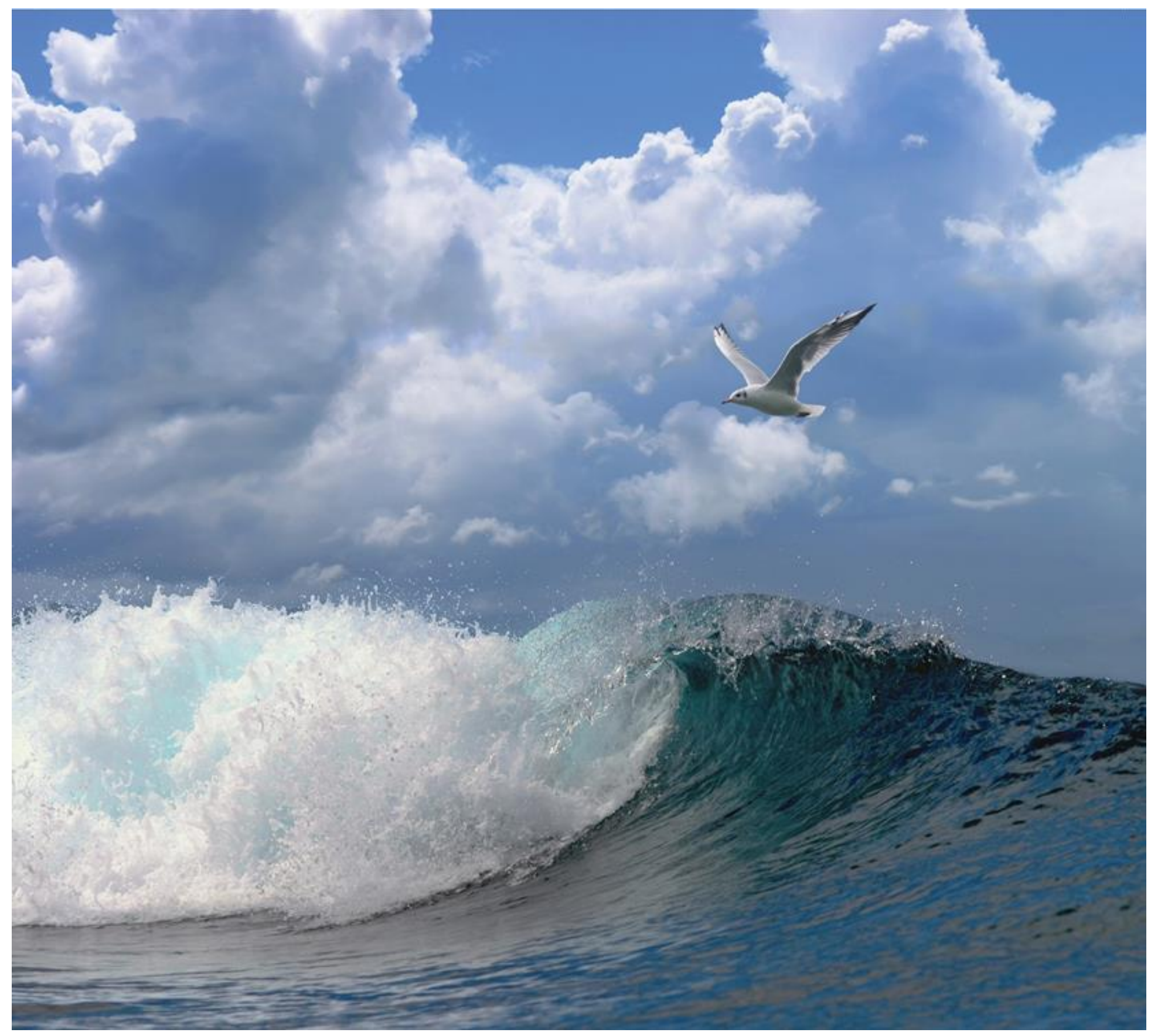

Comparison of Whole Effluent Toxicity with Substance Based Hazard of produced water discharged by Norwegian platforms 


\section{Comparison of Whole Effluent Toxicity with Substance Based Hazard of produced water discharged by Norwegian platforms}

Author(s): $\quad$ Pepijn de Vries and Robbert Jak

Publication date: 8 November 2018 
Pepijn de Vries and Robbert Jak, 2018. Comparison of Whole Effluent Toxicity with Substance Based Hazard of produced water discharged by Norwegian platforms. Wageningen Marine Research (University \& Research centre), Wageningen Marine report C080/18. 84 pp.

Client: $\quad$ Equinor ASA

Attn.: T.K. Frost

7035 Trondheim

NORWAY

Client: $\quad$ Norwegian Oil and gas Association

Attn.: E. Lystad

Vassbotnen 1

P.O. Box 8065

4068 Stavanger NORWAY

This report can be downloaded for free from https://doi.org/10.18174/464051

Wageningen Marine Research provides no printed copies of reports

Wageningen Marine Research is ISO 9001:2015 certified.

(C) 2018 Wageningen Marine Research

Wageningen Marine Research, an institute Wageningen Marine Research accepts no liability for consequential damage, nor within the legal entity Stichting for damage resulting from applications of the results of work or other data Wageningen Research (a foundation under obtained from Wageningen Marine Research. Client indemnifies Wageningen Dutch private law) represented by Dr. Marine Research from claims of third parties in connection with this application. M.C.Th. Scholten, Managing Director All rights reserved. No part of this publication may be reproduced and / or

KvK nr. 09098104, published, photocopied or used in any other way without the written permission WMR BTW nr. NL 8113.83.696.B16.

Code BIC/SWIFT address: RABONL2U IBAN code: NL 73 RABO 0373599285 


\section{Contents}

$\begin{array}{lr}\text { Summary } & \mathbf{5}\end{array}$

$\begin{array}{llr}1 & \text { Introduction } & 8\end{array}$

$\begin{array}{llc}1.1 & \text { Background } & 8\end{array}$

1.2 Risk Based Approach (RBA) 8

$\begin{array}{lll}1.3 & \text { Implementation process of the RBA } & 8\end{array}$

$\begin{array}{ll}1.4 & \text { Objective }\end{array}$

2 Methods $r$

2.1 Included platforms and operators on the NCS 10

2.2 Calculating WET based hazard 11

2.3 Collecting and selecting toxicological data for the Substance Based Hazard 11

2.3.1 Algae and crustacea 11

2.3.2 Bacteria 12

2.4 Calculating Substance Based Hazard 13

2.5 Comparing Substance with WET Based Hazard 16

2.5.1 Visual presentation 16

$\begin{array}{ll}2.5 .2 & \text { Statistical analysis }\end{array}$

$3 \quad$ Results and discussion $\quad 20$

3.1 Calculating WET Based Hazard $\quad 20$

3.2 Collecting and selecting toxicological data for the Substance Based hazard 20

3.2.1 Algae and crustacea 20

3.2.2 Bacteria $\quad 23$

3.3 Calculating Substance Based Hazard $\quad 24$

3.4 Comparing Substance with WET Based Hazard $\quad 29$

$\begin{array}{ll}3.4 .1 & \text { Visual presentation }\end{array}$

3.4.2 Statistical analysis

$4 \quad$ Conclusions and recommendations 48

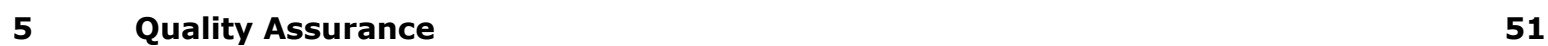

$\begin{array}{lr}\text { References } & 52\end{array}$

$\begin{array}{lr}\text { Justification } & 54\end{array}$

$\begin{array}{lll}\text { Annex } 1 & 55\end{array}$

$\begin{array}{lll}\text { Annex } 2 & \text { Selected toxicity data (crustacea and algae) } & 58\end{array}$

$\begin{array}{llr}\text { Annex } 3 & \text { Selected toxicity data (bacteria) } & 68\end{array}$

$\begin{array}{lll}\text { Annex } 4 & \text { Norwegian implementation scheme for the RBA } & 69\end{array}$

$\begin{array}{lll}\text { Annex } 5 & \text { Toxic Units as calculated with the Substance Based approach } & 70\end{array}$

$\begin{array}{lll}\text { Annex } 6 & \text { Whole effluent toxicity tests that failed acceptance criteria } & 76\end{array}$

$\begin{array}{lll}\text { Annex } 7 & \text { Specific selection criteria applied to ecotoxicological data } & 78\end{array}$ 
Annex 9 Principal Component Analyses

Annex $10 \quad$ Additional scatter plots

82 


\section{Summary}

At the beginning of the millennium OSPAR policy on produced water discharges focused on oil in water and the application of Best Available Technique (BAT) and Best Environmental Practice (BEP) associated with oil. In 2009 the OSPAR Offshore Industry Committee (OIC) agreed to set up an Intersessional Correspondence Group on development of a risk-based approach (RBA) for the management of produced water discharges (ICG-RBA), with the task of developing a proposal for a holistic approach for the management of produced water discharges from offshore installations. This was referred to as the risk based approach. The ICG-RBA also developed the draft OSPAR Recommendation 2012/5 for a risk-based approach to the management of produced water discharges from offshore installations and associated Guidelines, that were adopted by OIC in 2012.

OSPAR provided guidelines which allow both Whole Effluent Toxicity (WET) testing and a Substance Based (SB) approach (using the substance composition), or a combination of these approaches to be used to assess the risk of produced water (PW) discharged. The goal is to continuously reduce the overall risk to the environment.

There is an ongoing debate on the comparability and complementarity of these two approaches. In the OSPAR SB approach, risk is calculated using PNECs mainly based on chronic toxicity data and are therefore based on lower assessment factors compared to the OSPAR WET based approach, where only acute toxicity data is generated and a maximum assessment factor (1000) is used. Furthermore, no attenuation factors (biodegradation, evaporation etc.) are accounted for in dilution/dispersion modelling in the WET approach, while this is accounted for in the formal SB approach.

The present study focused on comparing hazards rather than risks of the two approaches to minimize dissimilarities between the methods e.g. by using similar toxicity data on similar test species and not account for fate processes such as biodegradation. The purpose of doing this was to determine how well both approaches agree with each other and whether the substances identified and selected included in the SB approach sufficiently cover the hazard of the produced water, indicating how well substances with toxicity (and risk) contribution are accounted for in Environmental Impact Factor (EIF) calculation of PW discharges on the Norwegian Continental Shelf (NCS).

The present study evaluated the hazard of 25 PW effluents sampled at 25 platforms of 6 different operators on the NCS that WET tests were undertaken for (step 3, Phase 2 of the Norwegian implementation plan; Annex 4). Both a WET based and a SB approach was used to estimate the acute hazards (rather than risk) by attempting to use similar input data at same conditions (e.g., exposure duration, test species and toxicity endpoints), such that these approaches could be compared in the best possible way, with as little noise as possible.

How well EIF substances cover the risk of a produced water discharge could not be concluded directly from the present study, as the present SB approach evaluated acute effects, whereas the EIF addresses chronic effects. Discrepancy between WET based and SB hazard can be the result of uncertainties in the composition (uncertainty in concentrations and the presence of "unknown" substances) and toxicity interactions in the produced water. These specific issues (e.g., uncertainty in added produced chemicals concentrations; presence of 'unknown' substances that are not measured during chemical characterisation) also apply to the EIF.

It should be noted that the present study was subject to several uncertainties: the lack of reliable toxicity data for the use in the SB based approach (often surrogate species, data generated under deviating conditions, or intra-/extrapolation techniques had to be used); limited number of species that WET tests were performed for (3 species per sample), where acceptance criteria for the toxicity test are often not met; grouping of chemicals, where chemical and toxicological properties varies within the group. It is therefore also recommended in future studies to improve these aspects, where 
possible, and to perform a power analysis for the statistics and data presented in the present study. This should provide more information on the sensitivity of the present experimental setup (how big do effects need to be in order to be detected). It will also provide insight into how the experimental setup can be improved and at what cost.

Despite the abovementioned uncertainties, the acute hazard matched reasonably well in the present study when comparing the WET based approach and the SB approach. In general, they were less than an order of magnitude (a factor of 10) apart. On average, the WET based approach resulted in a slightly higher hazard than the SB approach. When added production chemicals were excluded from the SB approach, the difference between the SB and WET based approach was increased, indicating that the SB approach underestimated the hazard more strongly when production chemicals were not included.

Despite the good match there was still some variance between the two hazard approaches. The largest part of the variation in the comparison between SB and WET based hazard remained unexplained. In other words: it remained unknown what caused the largest part of the differences observed between WET and SB hazard estimates. On average the WET based approach indicated a larger hazard than the SB approach. This suggested that on average either not all relevant substances with potential contribution to the overall toxicity of PW were included in the SB approach, toxicity of one or more substance groups were underestimated, not all toxic interactions were correctly included in the SB approach, or a combination of these aspects. The average difference was however small.

It was found that added production chemicals, organic acids or aliphatic hydrocarbons dominated the acute SB hazard for the selected platforms. These substance groups affected the difference found between SB and WET based hazard to some extent. For aliphatic hydrocarbons, toxicity was expected to be overestimated (and its effect concentrations thus underestimated) in the SB approach using heptane as a representative for this group (when compared to the WET based hazard). In the case of production chemicals, where large variation was found in the SB hazard estimates, this was probably caused by the fact that discharge concentrations were estimated rather than measured in the effluent. On average the production chemicals also seem to result in a slight overestimation of the SB based hazard. When organic acids dominated the overall hazard, the SB hazard (expressed as 50\% hazardous concentration or $\mathrm{HC50}$ ) was lower when compared to the WET based approach. Whether this was caused by the high acute toxicity of organic acids themselves or the fact that the hazard was not dominated by aliphatic hydrocarbons nor by production chemicals, was not clear.

The difference between the estimated SB and WET based hazard also differed significantly for the different operators. In the present study no obvious explanation could be provided for the observed difference between operators. Possible causes for the differences between operators are: different ways of estimating discharge concentrations of added chemicals used in estimating the SB hazard; differences in sampling and handling of samples for WET tests; differences in the composition of the effluent (in particular 'unknown substances' that were not measured during the chemical analysis). The first suggestion (differences in the way added chemical concentrations are estimated) is the most plausible. It is therefore recommended to have a closer look at potential differences between the operators and determine whether these differences can explain the effects observed here.

In this study, comparing hazards rather than risks of the SB and WET approach, showed that even when similar conditions (e.g., exposure duration and test species) were pursued for both hazard approaches, results (although in the same range) differ due to uncertainties in the input data and differences between the approaches that cannot be eliminated. This suggests that the information obtained from the WET tests and a SB approach are complementary and should not be used interchangeably.

Overall, in the present study the acute hazard was compared between the WET based and SB approach. Some variation was found, although differences were generally within an order of magnitude. However, the overall goal of OSPAR's risk based approach is the reduction of risk. It may thus be more valuable to evaluate whether both approaches indicate similar reduction of hazard over time, when both the WET based and SB approach are used to monitor the hazard of a platform's 
discharge over time. This opposed to comparing the two approaches on an absolute scale at one point in time (as was done in the present study). For the next risk based assessment cycle, it is recommended to evaluate the hazard reduction for effluent discharges and compare these reductions using the WET based versus the SB approach. This will only work when identical procedures for estimating hazard are followed at both time intervals. 


\section{Introduction}

\section{$1.1 \quad$ Background}

OSPAR is committed to taking all possible steps to prevent and eliminate pollution from offshore sources and in particular to achieve a reduction in discharges of hazardous substances via produced water, by making every endeavour to move towards the target of cessation of discharges of hazardous substances by the year 2020, with the ultimate aim of achieving concentrations in the marine environment near background values for naturally occurring substances and close to zero for manmade synthetic substances (OSPAR, 2013).

OSPAR Recommendation 2001/1 focuses on oil in produced water and the application of Best Available Technique (BAT) and Best Environmental Practice (BEP) associated with oil. But discharges of produced water also contain other substances, such as heavy metals, aromatic hydrocarbons, and alkylphenols which are present in the hydrocarbon reservoir, and added chemicals that are used during the production and produced water treatment processes. Therefore, there was a need to move forward towards a more holistic approach rather than focusing solely on oil in produced water discharges. At the 2008 meeting of the Offshore Industry Committee (OIC) it was decided that a Risk Based Approach (RBA) should be developed for the management of produced water (OSPAR, 2008). In 2009 the OSPAR OIC agreed to set up an Intersessional Correspondence Group on development of a risk-based approach for the management of produced water discharges (ICG-RBA), with the task of developing a proposal for this approach.

\subsection{Risk Based Approach (RBA)}

The RBA is a method of prioritising mitigation actions on those discharges and substances that pose the greatest risk to the environment (OSPAR, 2013). In the RBA all substances present in the produced water potentially contribute to the total risk. The RBA will determine the magnitude of the total risk and, where appropriate, which substance or group of substances that contributes most to the total risk. Furthermore, it will determine whether exposure levels in the receiving environment relating to the discharge, or specific components of the discharge, indicate that the risk is adequately controlled or not, so that Contracting Parties can take the most effective risk reduction management measures. The ICG-RBA developed the draft OSPAR Recommendation 2012/5 for a risk-based approach to the management of produced water discharges from offshore installations (OSPAR, 2012a) and associated Guidelines. The OSPAR guidelines (OSPAR, 2012b) prescribe that the risk will be characterised on the basis of Whole Effluent Toxicity (WET) studies and/or an assessment of the individual substances or groups of substances, identified in the produced water, taking account of the exposure relating to the discharge and the sensitivity of the receiving marine environment. If the risk is not considered to be acceptable, appropriate measures based on BAT and BEP will be required to be implemented by industry to avoid or minimise the risk. This approach will be implemented for all offshore installations with produced water discharges in the OSPAR maritime area (OSPAR, 2013).

\subsection{Implementation process of the RBA}

All Contracting Parties have finalised their implementation plans for the RBA in 2013, with the aim of achieving full implementation by 31 December 2018. Starting in 2014, Contracting Parties will report annually on progress during the implementation period, through the OSPAR Offshore Industry Committee (OIC), and the Committee will undertake an evaluation of the effectiveness of the RBA every five years after 2018 (OSPAR, 2012a). The objective is that by 2020 all offshore installations with produced water discharges in the OSPAR maritime area will have been assessed to determine the level of the risk and that, where appropriate, measures will have been taken to reduce the risk posed by the most hazardous substances (OSPAR, 2013). 
The Norwegian Environment Agency have adopted the Environmental Impact Factor (EIF), which was already implemented following the White Paper of 1996, for this purpose. Annex 4 illustrates the Norwegian implementation scheme for the RBA. EIF (Smit et al., 2011) is selected as a leading methodology in the RBA, representing the SB approach. However, both approaches have however been applied in the RBA implementation on the NCS, starting with the SB approach used as a risk screening approach (referred to as Phase 1). Based on the output from the risk screening, WET is conducted to a selection of PW effluents with subsequent analysis (referred to as Phase 2).

The study presented here is part of step 4 of Phase 2 of the implementation plan.

\subsection{Objective}

The RBA requires the risk of produced water discharges to be assessed with either a WET based approach, or a substance based (SB) approach or a combination of these two approaches. There is still much ongoing debate on the comparability and complementarity of these two approaches. De Vries and Karman (2011) already made an initial comparison of the approaches based on a pilot study with 30 platforms situated in the North East Atlantic Ocean. They concluded that (given the methodologies proposed at the time) that the SB approach was generally more conservative than the WET based approach and the correlation between the two was poor. However, De Vries and Karman (2011) identified several limitations, with the main issues being:

- Toxicological information of the 'added' production chemicals was included differently for each platform (some assumed each product was represented entirely by the most toxic component, while others included information on each individual component).

- $\quad$ The comparison was based on Predicted No Effect Concentrations (PNECs) with large differences in the available toxicological information and between applied methodology on which the information is based:

- For natural substances chronic toxicity data were sometimes available while for WET only acute toxicity were available, and therefore higher assessment factors were applied to determination of PNEC (to account for uncertainty) for WET data compared to natural substances in the SB approach. The magnitude of the assessment factor applied to the PNEC also varies among the substances;

- They were based on a wide range of test species (that may not be similar to the species tested with the whole effluent;

- Test conditions were highly variable.

Therefore, in the present study, the analysis was repeated for 25 Norwegian platforms. However, this time, the information of the 'added' production chemicals was included in a consistent (most realistic) way and acute toxicological data of the 'natural' components was collected to reflect the test species, toxicity endpoints and conditions that were used in the WET tests.

The key research question of the present study was how well the acute WET based hazard matches with the SB hazard predicted from the combined acute hazard of individual substances identified in the PW. And in addition, whether the natural substances (currently measured) and added chemicals (estimated) included in the risk calculations (EIF) for Norwegian legislation are sufficiently covered in the overall acute hazard predictions of produced water (in comparison with WET). 


\section{Methods}

For a selected number of platforms (see section 2.1), the hazard of the discharged produced water (PW) was determined for both the WET approach and the SB approach. This chapter describes the steps required to quantify the hazard with both approaches and how they were compared.

In order to assess the hazard based on chemical composition of the produced water (PW) effluent, data was required not only on the composition, but also on the acute toxicity of the substances. Information on the chemical composition of the produced water samples was provided by the client and includes both 'naturally' occurring substances from the reservoir and added chemicals, which were used to facilitate the oil extraction process. Ecotoxicological information was selected such that it matches best with the WET tests performed with the same PW samples. Section 2.3 describes how the toxicity data was selected, section 2.3 describes how the information on the PW composition and toxicity of the substances was combined in order to quantify the hazard.

The WET test was performed with three marine species that have been selected for the Norwegian implementation of OSPAR's risk based approach: Skeletonema costatum (algae), Acartia tonsa (crustacean) and Vibrio fischeri (bacteria, Microtox). Toxicity was tested with acute exposure durations for each of these species. Therefore, acute toxicity data for the same or similar species was intended to be collected in the SB approach. Section 2.2 describes how the WET test results were used to quantify the WET based hazard.

The last step comparing the SB and the WET based hazard is described in section 2.5. The results are described in chapter 3, where they are presented in the same order as the corresponding sections in this chapter.

\subsection{Included platforms and operators on the NCS}

The present study involved 6 operators that are active on the NCS. PW discharge samples were evaluated for 14 platforms of Equinor, 4 platforms of Aker BP, 2 platforms of ConocoPhillips, 2 platforms of Point Resources (formerly operated by ExxonMobil), 2 platforms of Shell and 1 platform of Wintershall. This makes a total of 25 platforms and 25 PW effluents that were included in the present hazard comparison study. A full list of platforms is given in Table 1.

\begin{tabular}{ll|ll}
\hline $\begin{array}{l}\text { Table 1. } \\
\text { Operator }\end{array}$ & List of selected platforms and corresponding NCS operators. \\
Equinor & Grane & Equinor & Platform / Efilluent \\
\hline Equinor & Gullfaks A & AkerBP & Veslefrikk \\
\hline Equinor & Gullfaks B & AkerBP & Alvheim \\
\hline Equinor & Gullfaks C & AkerBP & Skarv \\
\hline Equinor & Heidrun & AkerBP & Ula \\
\hline Equinor & Norne & ConocoPhillips & Valhall \\
\hline Equinor & Snorre A & ConocoPhillips & Ekofisk J \\
\hline Equinor & Snorre B & Point Resources & Bafisk M \\
\hline Equinor & Statfjord A & Point Resources & Jotun \\
\hline Equinor & Statfjord B & Shell & Draugen \\
\hline Equinor & Statfjord C & Shell & Knarr \\
\hline Equinor & Troll B & Wintershall & Brage \\
\hline Equinor & Troll C & & \\
\hline
\end{tabular}




\subsection{Calculating WET based hazard}

WET based hazard uses effect concentrations as determined in the WET tests to quantify the hazard. Effect concentrations (EC50 or LC50; for simplicity both referred to as EC50 in the remainder of the text) were provided by the client expressed as percentage PW effluent. In the calculations used here the EC50 values needed to be expressed as dilution factors (by dividing 100 with the EC50 value expressed as \% effluent). When an effect concentration (EC50) expressed as percentage was reported as 'less than', the concentration was divided by a correction factor of 2 . This occurred for 4 of the tested effluents where the $50 \%$ effect level for $S$. costatum was beyond the tested dilution range. The minimum tested concentration was $1 \%$ corresponding with a dilution factor of 100 . The correction factor of 2 was applied as a pragmatic method to acknowledge that the effect concentration was in fact larger than the reported dilution factor of 100 (or smaller than $1 \%$, when expressed as percentage).

The hazard needs to be quantified as the $50 \%$ hazardous concentration (HC50), which is the concentration (expressed as dilution factor of the effluent) at which $50 \%$ of the species are potentially affected. In the present study this means that the HC50 is the concentration at which $50 \%$ of all relevant test species ( $V$. fischeri, S. costatum and $A$. tonsa) are potentially affected (at or above their $50 \%$ effect concentration). Although the HC5 (the 5\% hazardous concentration at which $5 \%$ of all species are potentially exposed (and thus affected) above their 50\% effect concentration) is often used in conservative risk assessment, the HC50 was selected here since this value can be calculated with higher precision and accuracy than the HC5. For effluents (e.g. produced water), this hazard concentration is expressed as dilution factor. For the WET based approach, the HC50 was calculated taking the geometric mean of the EC50 of all three tested species ( $V$. fischeri, S. costatum and $A$. tonsa).

\subsection{Collecting and selecting toxicological data for the Substance Based Hazard}

This section describes how toxicity data was collected for use in the SB approach. The resulting data set is described in the results chapter, in section 3.2 and listed in Annex 2 and 3.

Acute (short-term) toxicity data on algae, crustaceans and bacteria was searched for in aquatic toxicity databases for all natural substances included in the EIF calculations, and included in the OSPAR standard list of which Predicted No Effect Concentrations (PNECs) are determined for, documented in the "OSPAR PNEC Background document" (OSPAR, 2014). In addition, data on organic acids characterized in PW and PLONOR production chemicals (MEG and methanol) used/discharged at high concentrations were collected. Organic acids are not included on the OSPAR PNEC list, but is included here since they potentially execute acute toxicity on organisms. For algae and crustacea the US EPA ECOTOX was used as the primary source of toxicity information. As the ECOTOX database does not contain bacterial data, the ECETOC Aquatic Toxicity Database (EAT) database developed in 2003 was used for that group of species. Although the latter database does contain data on algae and crustacea, it was not used in combination with the first database (which is more complete), to avoid duplicated data.

\subsubsection{Algae and crustacea}

The complete EPA ECOTOX database was downloaded (https://cfpub.epa.gov/ecotox/, release of 15 December 2015). Screening, analyses and selection steps were performed in R (R Foundation for Statistical Computing, Vienna). Some pre-filtering was done to produce a more manageable toxicity data set, where all irrelevant information was excluded:

- Tests performed in water (both freshwater and saltwater) were selected from the database.

- Toxicity data on EIF substances (plus organic acids and PLONORs MEG and methanol) were selected from the database (see Annex 1 for the list). This selection was based on Chemical 
Abstract Service (CAS) number for the organic substances (see Annex 1). The metals were first selected based on the metal ion. Preferably the chloride salts were selected for each metal. Other salts were selected when data was unavailable/limited.

- Only tests with (acute) EC50 (primarily algae) and LC50 (crustacean) endpoints were selected from the database.

- Only test species in the subphylum "Crustacea" and in the EPA ECOTOX group "Algae" were selected.

This resulted in a data set which was used as a basis for the SB approach. Unfortunately, there was insufficient data for each specific EIF substance. Therefore, toxicity data were collected per EIF substance group. For each substance group, specific selections were made, based on the availability of the data and the matching with the test conditions and species used in the WET tests. Table 7.1 (Annex 7) lists the specific selection criteria that were applied.

In the WET tests the marine species crustacean Acartia tonsa with mortality as endpoint (LC50) and algae Skeletonema costatum with growth inhibition (EC50) as endpoint were used. In the toxicity tests used for the registration of substances in (added) production chemicals under the Harmonised Offshore Chemical Notification Format (HOCNF), A. tonsa is also tested as well as a marine algae (not necessarily S. costatum). Therefore, in the selection of toxicity data for natural substances, we focused on these two test species.

If no (comparable) data was available for $A$. tonsa (for instance no similar endpoints and no exposure durations), data was collected for other similar copepod species. If no data was available for copepods, the species most closely related to copepods was selected from the database. Similarly, if no data was available for $S$. costatum, data was collected for other diatoms. If no data was available for diatoms, other (preferably marine) algae were used as a substitute. Table 7.1 (Annex 7) lists the applied specific selection criteria.

\subsubsection{Bacteria}

Microtox (a bio-assay with luminescent marine bacteria) was also performed with the whole effluent. Unfortunately, the US EPA ECOTOX database does not contain any bacterial toxicity data. The client provided a copy of the ECETOC Aquatic Toxicity (EAT 5) database, from which relevant bacterial toxicity data was selected.

From the EAT database the relevant substances were selected based on CAS number for the organic substances and based on the substance names for the inorganic substances. All bacterial assays listing an EC50 were selected in the database (which mostly were Microtox assays). Toxicity data based on tests with an exposure duration between 12 and 18 minutes (15 minutes is used in the WET tests) were then selected. For EIF groups where tests with such an exposure duration were not available, the test with the duration closest to that used in the WET tests (15 minutes) was selected.

In the EAT database, effect (light emission inhibition) concentrations (IC50 = EC50) values are reported in $\mathrm{mg} / \mathrm{L}$. These were converted into $\mu \mathrm{mol} / \mathrm{L}$, by dividing the concentration by the molecular weight as listed in the database.

The above described selection procedure resulted in specific EIF groups for which there were no relevant bacterial toxicity test data. The same was true for the added production chemicals for which Microtox data is usually not included in the HOCNF. Therefore, the missing data was estimated using an "Interspecies Correlation Estimate" (ICE) approach. With ICE, the toxicity for a substance is estimated based on the measured toxicity for a surrogate species. Data from Zhang et al. (2010) was used to derive the following relationship, using algae as surrogate species as they have the highest correlation with the Microtox data in that dataset (conform other ICE relationships derived by the authors):

$$
\ln \left(1 / E C 50_{V . f i s c h e r i}\right)=0.4758-0.7016 \cdot \ln \left(1 / E C 50_{\text {algae }}\right)
$$


Which can be rewritten as:

$$
E C 50_{V . f i s c h e r i}=e^{-0.4758+0.7016 \cdot \ln \left(1 / E C 50_{\text {algae }}\right)}
$$

Note that the ICE relationship was used to generate data for missing experimental data. The substances to which it was applied may not necessarily fall within the domain of the model. Furthermore, the correlation of the relationship is weak $\left(r^{2}=0.61\right)$. The ICE predictions should be considered as indicative only.

\subsection{Calculating Substance Based Hazard}

Ecological hazard was also calculated from the chemical substance composition of the sampled produced water. For some specific substances insufficient toxicity data was available and these substances were therefore grouped, based on chemical similarity. Concentrations of substances in these groups (EIF groups) were first converted to $\mu \mathrm{mol} / \mathrm{L}$ and then summed to obtain the total concentration of each group. The following chemical groups were used in the present analysis (based on the groups also used for the calculation of the EIF) and include the naturally occurring substances that OSPAR have been determined PNECs for: Benzene, Toluene, Ethylbenzene and Xylenes (BTEX); Naphthalenes; Polycyclic Aromatic Hydrocarbons (PAH) 2-3 ring; $\mathrm{PAH} 4+$ ring; alkylphenols C0-C3; alkylphenols C4-C5; alkylphenols $\mathrm{C} 6+$; and heavy metals. Organic acids, which are not part of the EIF due to their low chronic toxicity, were also included in the present hazard study due to their acute toxicity potential which is also measured in the WET tests.

A complete list of 'natural' substances and substance groups identified in PW can be found in Annex 1 . Effluent concentrations of substances used in the present study were provided by the client, and originated from chemical analysis of PW samples collected simultaneously with the samples for the WET tests following the Norwegian Oil and Gas recommended guidelines (NOG, 2012). When a concentration for a 'natural' substance was below the detection limit of the analytical method, the discharge concentration was assumed to be equal to half this limit, as a most realistic estimate.

For the added chemicals, estimated discharge concentrations on component level were applied as input. Concentration estimates were also provided by the operators of the selected platforms. Substances posing little or no risk to the environment (PLONORs) are normally not included in the risk (EIF) calculations due to their low toxicity. Exceptions are the PLONORs monoethylene glycol (MEG) and methanol as they are used and discharged in large quantities.

There are several options for estimating the discharge concentrations of added chemicals. In the present hazard study, the best possible discharge concentration estimates for added chemicals (on individual components) in the effluent for the day the of sampling (for WET testing) was aimed for (option 1). Additional options (2, 3, and 4) were also addressed and included in the present study:

- Option 1: best estimate for the day of PW sampling;

- Option 2: estimate based on average for the month of the PW sampling;

- Option 3: estimate based on annual average ${ }^{1}$;

- Option 4: exclude added chemicals all together.

Furthermore, some chemicals may retain a while in the system after being applied, before it will end up in the effluent and will be discharged. Option 1 may therefore not necessarily produce the best results. Therefore, due to the large uncertainties in the estimates of discharge concentrations of added chemicals, all options listed above were included to test the effectiveness of the methodology. Most often, estimates on amounts of added chemicals discharged via PW are based on octanol/water partition coefficients $\left(\log \mathrm{K}_{\mathrm{ow}}\right)$ indicating distribution of the chemical components between oil that is retained and water that is discharged. For some added chemicals (e.g. surfactants) this extrapolation (using logKow) does not provide a realistic estimate, and lately improved and in some cases

\footnotetext{
${ }^{1}$ not available for platform Draugen
} 
experimental based approaches for estimation of chemical distribution have been provided (Aas et al. 2002). This approach was also applied by the client to the discharge concentrations as provided for and included in the present study.

For the SB hazard a procedure similar to that proposed by De Zwart and Posthuma (2005) and Smit et al. (2008) is followed. In the present study the SB hazard was (similar to that based on the WET tests) expressed as the HC50 (hazard indicator). This HC50 is located at the centre of an s-shaped hazard curve, commonly referred to as the Species Sensitivity Distribution (SSD) as illustrated in Figure 1.

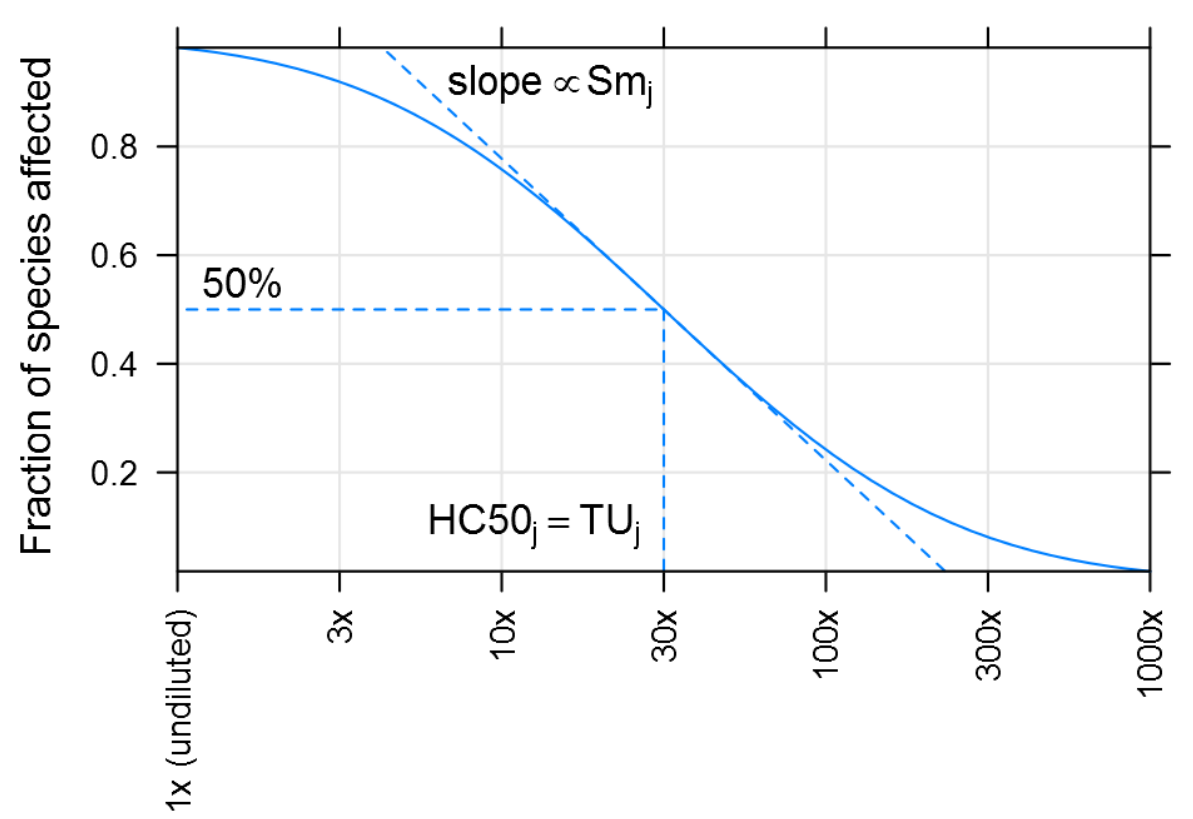

\section{Dilution factor}

Figure 1. An example of a Species Sensitivity Distribution (SSD or hazard curve) for a substance with Toxic Mode of Action $j\left(T M o A_{j}\right)$. In this example substances with $T M o A_{j}$ in the undiluted effluent affects all species at or above their $50 \%$ effect concentration. When the effluent is diluted by a factor of 30, the $50 \%$ hazardous concentration (HC50) for $\mathrm{TMOA}_{j}$ is reached in this example. The slope (Sm) is assumed generic for each TMOA. The overall HC5O is calculated by combining the SSDs for all the TMoAs.

The procedure followed to derive the HC50 in the present study involved the following steps. As already mentioned, for each EIF substance group the total discharge concentration was estimated by summation of individual concentrations within each EIF substance group (in $\mu \mathrm{mol} / \mathrm{L}$ ). Next, geometric mean of EC50/LC50s (converted to $\mu \mathrm{mol} / \mathrm{L}$ ) for each test species $k$ (algae, crustacean and bacteria) for each EIF substance group was calculated from the collected toxicity data (section 2.2) and was called $X m_{k}$. For each EIF substance group the geometric mean of the geometric means for each species $\left(X m_{k}\right)$ was taken and called $X m_{i}$. The geometric means was thus applied twice: Once for each test species within a substance group, than for all species within that group.

Thereafter, the toxic unit (TU) was calculated per EIF substance group $i$ (e.g., PAH 4+ ring):

$$
T U_{i}=\frac{C_{i}}{10^{X m_{i}}}
$$

Where $C_{i}$ is the total discharged concentration of EIF substance group $i . \mathrm{X}_{i}$ is the geometric mean of LC50/EC50 values for the three selected species tested for EIF substance group $i$. Using the sum of TUs for each EIF substance groups representing the PW effluent, an indication of the contribution to the hazard from each EIF group was visualised for each platform. 
For further calculation of the HC50 the toxic units were summed per toxic mode of action (TMoA) $j$ :

$$
T U_{j}=\sum_{i} T U_{i, j}
$$

The various substance/substance groups have different TMoAs. For example, benzene is assumed to act via Nonpolar Narcosis (NN), whereas phenol is assumed to act via Polar Narcosis (PN).

Furthermore, each metal was assigned its own specific TMoA. The slope $\left(S m_{j}\right)$ which is the standard deviation; indicating the difference in species sensitivities in the hazard curve, for the group with an unknown TMoA was based on the median slope found for all substances (acting via any and all TMoA) studied by Harbers et al. (2006).

A complete list of TMoAs and the associated SSD slopes $\left(\mathrm{Sm}_{j}\right)$ for the EIF substance groups are listed in Table 2. Substances with the same TMoA act on the same target site and therefore compete for the same target. In this study, all alkylphenol groups were assigned polar narcotic (PN) TMoA and organic acids, BTEXs, naphthalenes, aliphatic hydrocarbons and PAHs were assigned non-polar narcotic (NN) TMoA. For substances or substance groups that have the same TMoA, the TUs were summed as they have been normalised to their median toxic concentration (EC50).

The calculation of the potentially affected fraction (PAF) of species for each TMoA $j$ (i.e., substance groups with same TMoA) for any dilution factor (dil_fact) was given by:

$$
\operatorname{PAF}_{j}(\text { dil_fact })=\text { pnorm }\left(\log _{10}\left(\frac{T U_{j}}{\text { dil_fact }_{-}}\right), \quad 0, \quad S m_{j}\right)
$$

Where pnorm is the cumulative normal distribution as a function of the quantile, mean and $S m_{j}$. Where the latter $\left(S m_{j}\right)$ is the standard deviation of log10 transformed toxicity data of substance groups with the same TMoA $j$ (i.e., the slope parameter of the SSD for TMoA $j$ ). Table 2 lists the slope parameter values for each of the TMoAs used in the present study. The TMoA labelled as "unknown" (UN) was assigned to all substances for which the TMoA was not known (all added chemical additives accept MEG and methanol). The slope for this group (with an unknown TMoA) was based on median

\begin{tabular}{|c|c|c|c|}
\hline \multicolumn{4}{|c|}{$\begin{array}{l}\text { Table } 2 . \quad \text { List of included toxic modes of action (TMOA) and their associated } \\
\text { standard deviation of log10-transformed toxicity data ( } \mathrm{Sm} \text {; i.e., slope parameter) }\end{array}$} \\
\hline TmoA & TMOA (Abbreviated) & $\sin (\log 10)$ & Reference \\
\hline Nonpolar Narcosis & $\mathrm{NN}$ & 0.65 & Harbers et al. (2006) \\
\hline Polar Narcosis & PN & 0.58 & Harbers et al. (2006) \\
\hline Unknown & UN & 0.85 & Harbers et al. (2006) \\
\hline Zinc & $\mathrm{Zn}$ & 0.98 & RIVM (2005) \\
\hline Copper & $\mathrm{Cu}$ & 0.98 & RIVM (2005) \\
\hline Nickel & $\mathrm{Ni}$ & $2.25^{2}$ & RIVM (2005) \\
\hline Cadmium & $\mathrm{Cd}$ & 1.12 & RIVM (2005) \\
\hline Lead & $\mathrm{Pb}$ & 0.98 & RIVM (2005) \\
\hline Mercury & $\mathrm{Hg}$ & $0.83^{2}$ & RIVM (2005) \\
\hline Arsenic & As & 0.98 & Crommentuijn et al. (1997) \\
\hline Chromium & $\mathrm{Cr}$ & 0.91 & Crommentuijn et al. (1997) \\
\hline
\end{tabular}
slope for all substances (with all TMoAs) as collected by Harbers et al. (2006).

For combining PAFs from substance/substance groups (multiple stressors) with dissimilar TMoAs, assuming that they act independently (different target sites), the multi-stressor PAF (msPAF) was calculated. The mSPAF of the combined TMOA groups was calculated for the range of dilution factors:

$$
\operatorname{msPAF}\left(\text { dil }_{-} f a c t\right)=1-\prod_{j}\left(1-\mathrm{PAF}_{j}\left(\text { dil }_{-} f a c t\right)\right)
$$

\footnotetext{
${ }^{2}$ This value deviates from the value listed incorrectly in the OSPAR guidelines
} 
The $\mathrm{p} \%$ Hazardous Concentration ( $\mathrm{HCp}$ ) was obtained by solving it from the equation above: $\operatorname{msPAF}\left(H C_{p}\right)=\frac{p}{100 \%}$. This was done numerically with $\mathrm{R}$ (A Language and Environment for Statistical Computing, R Core Team, R Foundation for Statistical Computing, Vienna, Austria).

\subsection{Comparing Substance with WET Based Hazard}

\subsubsection{Visual presentation}

Firstly, the results are presented visually and were discussed as such in section 3.4.1. The SSD hazard curves were presented for each PW effluent for each platform, where both the substance and WET based hazard curve were presented in the same plot. For the WET based curve, the $95 \%$ confidence intervals were calculated based on the approach described by Aldenberg et al. (2002), where the three species EC50 values were assumed to be distributed log-normally. Although the SB hazard estimates also contained uncertainties, they could not be quantified in a similar fashion, as they are constructed based on different types of information.

A scatter plot of the SB HC50 estimates versus those based on the WET test for each platform was generated. When both approaches result in an identical HC50 value, they would line up as a diagonal line $(y=x)$, when plotted in such as a scatter plot. Differences between the approaches were therefore expressed as the perpendicular distance to the line $y=x$ (where both $y$ and $x$ are on a logarithmic scale). This distance was also used in ordinary linear regression (ANOVA), in order to study if there were any factors that affect this distance, as described in more detail below (section 2.5.2.1). Note that the distance can be positive (when the SB HC50 is larger than the WET based $\mathrm{HC50}$ ), or negative (when the SB HC50 is smaller than the WET based HC50). This distance was calculated from the ratio between the WET based HC50 and the SB HC50:

$$
\text { dist }=\frac{1}{\sqrt{2}} \log _{10}\left(\frac{H C 50_{\text {substance }}}{H C 50_{\text {WET }}}\right)
$$

Deming regression was also applied to visually inspect how well the HC50 values for both approaches aligns with the diagonal line $(y=x)$. Deming regression differs from ordinary linear regression in that it will minimize the error perpendicular to the fitted line, whereas ordinary regression minimizes the error in the $y$-axis direction (therewith assigning more importance to the parameter on the $y$-axis).

In section 2.5.2.1 a Principal Component Analysis (PCA) is described to capture the variation in chemical composition of the discharges analysed in the present study. This approach is very useful in the statistical analysis but is not easy to present intuitively. Therefore, the same information is also presented visually using a hierarchical clustering method (Murtagh and Legendre, 2014) for option 1. Results displayed in a cluster tree will show platforms, where the hazard contribution of substance groups are similar on the same branch of a tree.

For some of the statistical analyses, it is useful to determine whether the chemical composition is associated with the operator. For this purpose, the 3 main branches of the cluster tree are taken, and for each branch it is counted how many platforms are operated by Equinor and how many by other operators on NCS. Using Fisher's exact test (Clarkson et al., 1993) for count data, it is determined whether the position on the cluster tree is associated with the operator. In other words, whether the chemical composition is related to the operator responsible for the discharge.

\subsubsection{Statistical analysis}

Using ordinary linear regression, the correlation (and its significance) was tested between the WET based HC50 and the SB hazard. Note that this method is slightly biased (because ordinary linear regression minimises the error only in the $y$-direction and not both in $x$ - and $y$-direction), and should only be used indicatively in this case. Unfortunately, Deming regression cannot be used directly for statistical testing. 
Most statistical tests applied in the present study (described below, based on ordinary linear regression) only compares a single point on the SSD curve (HC50). The full SSD curves (based on the substances and on the WET tests) including the range of $\mathrm{HC}$ values was also compared. The SSD curves based on the substance characterisation and the WET tests were compared pairwise, using the Kolmogorov-Smirnov (KS) test. For this test it was assumed that either of the two SSD curves was the theoretical risk curve (for which the SB SSD was used) and one was the observed risk curve (for which the WET based SSD was used). The null hypothesis was that the observed distribution was sampled from the theoretical distribution (i.e., both WET and SB SSD are similar). In other words, when the null hypothesis was rejected, it was unlikely that the SB SSD curve was similar to that of the WET based SSD curve.

An alpha level of $0.05(p<0.05)$ was used for the KS tests. This means that there was a $5 \%$ chance that the rejection of the null-hypothesis was based on coincidence. As the comparison was done for multiple platforms, it was tested how likely it was that a rejection of the null-hypothesis for multiple platforms was based on coincidence. Using Chi-squared statistics, it was derived that if for four or more of the 25 examined effluents the KS null-hypothesis was rejected it was unlikely due to mere coincidence $(p<0.05)^{3}$.

\subsubsection{Systematic and random differences}

Unfortunately, it can't be studied whether the contribution of EIF substances (groups) to the hazard affect this distance directly. In good statistical models (much) more observations than explanatory variables are needed. Here, the number of substance (groups) were comparable to the number of effluents, making it impossible to include all individual substance (groups) in the model. In addition, the variance in the produced water composition was expected to be limited and the contribution to the hazard was expected to be correlated between substance (groups). For instance, it was expected that for most Norwegian platforms the production chemicals have the largest contribution to the total hazard. When this contribution is reduced the contribution of the second highest contributor will increase.

To overcome this problem, a principal component analysis (PCA) was performed. The contribution to the total hazard was calculated for each platform as the TU of the substance (group) divided by the sum of TUs for all substance (groups) $\left(T U_{i} / \sum_{i} T U_{i}\right)$ (note that effects/interactions of the TmoA was ignored). This contribution was therefore a number between 0 (low contribution to hazard) and 1 (high contribution to hazard). Before the PCA, this number was $\log _{10}$-transformed, scaled and normalised (such that the mean was 0 , and the standard deviation was 1 ). These scaling steps applied to the TUs were only applied in the PCA. The PCA reduced the variation in hazard contribution of the different substance (groups) to so called principal components. All substance (group)s were represented to some extent in each principle component. The scaled TUs were also used to perform a cluster analysis. This allowed to visually display the similarity between effluent in a cluster tree, where similar effluents were on the same branch of the tree.

The first three principal components (the components that explain most variance in hazard contribution) was used in a statistical model (using ordinary linear regression) to explain the variation observed distance between the substance and WET based hazard. In ordinary linear regression, the difference between the regression line (i.e. predicted response value) and the observed response

\footnotetext{
${ }^{3}$ We have 25 effluents and assume that for $5 \%$ of the effluents the KS null hypothesis are rejected as a result of coincidence (random chance). The expected rejection rate is thus $5 \%$ of $25(1.25)$ and we expect that $95 \%$ of the effluents are not rejected (23.75). If we observe that for 3 effluents the KS test is rejected (which is more than the expected 1.25 effluents) the Chi squared can be calculated as follows:

$$
\chi^{2}=\sum \frac{(\text { observed_frequency }- \text { expected_frequency })^{2}}{\text { expected_frequency }}=\frac{(3-1.25)^{2}}{1.25}+\frac{(22-23.75)^{2}}{23.75} \approx 2.579
$$

This value is less than the critical $\chi^{2}$ value of 5.024. This means that when we observe 3 effluents for which the KS test is rejected, this is not significantly more than what you would expect based on random chance. When we repeat the same calculations for the case where we observe 4 effluents for which the KS test is rejected we get $\chi^{2}=6.368$, which is larger than the critical value of 5.024. This means that when there are 4 or more platforms for which the KS is rejected, this no longer can be attributed to random chance.
} 
variable (in this case dist) is minimized, by changing the values of the slope parameters (in this case $a$ up to $d$ ) and the intercept. Expressed as an equation, the statistical model is formulated as (Eqn 1):

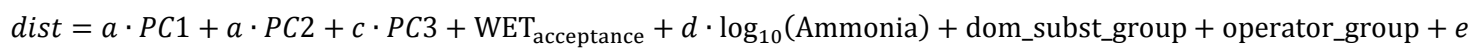

Letters $a$ up to $d$ are slope parameters that were fitted through ordinary linear regression. $e$ is the intercept that was fitted by means regression as well. For non-numerical variable (i.e., categorical information; these were the variables that were not preceded by a slope parameter) an offset was fitted for each category level. $P C 1, P C 2$ and $P C 3$ were the first three principal components, representing the contribution to the SB hazard from different substance groups. With this approach it was determined if the contribution of substance (group)s to hazard significantly explains differences found between the WET based and SB HC50. Unfortunately, these effects could not be pinned on specific substances, although likely suspects were identified with the PCA.

'WET_acceptance' is a categorical variable indicating how many WET tests failed for each platform failed, not fulfilling the acceptance criteria set for each WET test (e.g. oxygen level below a critical level in the test solutions), to such an extent that it could have affected the determined effect concentration for the test species. It was expected that a test organism will be more sensitive when acceptance criteria are not met, and in several cases will have influenced the calculated EC50 value and therefore the WET based hazard was thus expected to be overestimated. In the statistical model 'WET_acceptence' was interpreted as non-numerical categorical information and an offset was fit for each level of the categories (i.e., the number of failed tests).

'Ammonia' is the ammonia concentration measured upon arrival at the laboratory. Ammonia was not included in the calculations of TUs, used for the SB approach. Recently, Parkerton et al. (2018) observed that ammonia was an important substance in produced water of platforms near Australia to predict acute toxicity of the effluent. Therefore, ammonia was included here to test whether the same is true for the platforms examined here.

'dom_subst_group' is a factor (non-numerical) indicating which EIF substance group dominates the SB hazard. In other words, the substance group for which $T U_{i} / \sum_{i} T U_{i}$ is largest. This tells whether there were structural effects for specific substance groups that dominate the hazard.

'operator_group' is a factor (non-numerical) indicating which operator group was responsible for the effluent discharge. As for many operators, only a limited number of samples were included in the analyses, they had to be grouped, resulting in the groups 'Equinor' (14 samples) and 'other operators' (11 samples). Effectively, the results for the Equinor platforms were compared to those of the other operators. Note that this factor studied any factor that was associated with the operator (including those resulting from the experimental setup).

The distance between the substance and WET based hazard (dist) was calculated for each platform, thus each platform was considered as a unique observation in this approach. An ANOVA was applied to the regression model to determine which explanatory variables explain a significant part of the variance in dist and how much of the variance is explained.

The regression model (Eqn 1) was only suited to detect systematic differences. In other words when effects were directed in a specific direction. For instance, when the WET tests were affected by failing acceptance criteria, it was assumed that the test organisms are more sensitive. This is a systematic effect which was detected with the ordinary linear regression approach described above (Eqn 1). However, in case failing test acceptance criteria unexpectedly affects the WET tests in both directions (in that case the test organisms can become both more or less sensitive when it fails acceptance criteria), the effect is not systematic but random. As a result, the mean value for dist can be the same for platforms with failed and successful tests, but the variance is expected to be larger for the failed tests. 
This can also be the case for the substance group that dominates the hazard. That too could have a random effect. For this purpose, Bartlett's test for equal variance was applied. The null hypothesis was that the variance within specific groups (such as groups with and without failed WET tests) was equal. When the null hypothesis was rejected, it means that the variance within each group was not equal to each other.

When random errors are larger under specific conditions, you would expect that the variance in the difference between WET based hazard and SB hazard (expressed as dist) is also larger for these conditions. Therefore, Bartlett's test of equal variance is applied to dist, in order to test whether the variance is larger for specific factors (e.g., hazard dominating substance group, operator, etc.). 


\section{Results and discussion}

\subsection{Calculating WET Based Hazard}

The results from WET tests on 25 PW effluents provided by the client are listed in Table 3, together with the HC50 values that were calculated with the method of Aldenberg et al. (2002).

Table 3. WET test acute EC50/LC50 concentrations (expressed both as percent and as dilution factors, i.e. the dilution factor required to reach $50 \%$ effect) as provided by the client. EC50 values reported as dilution factors greater than (">") are multiplied by a correction factor of 2 in the comparison analysis.

\begin{tabular}{|c|c|c|c|c|c|c|c|}
\hline \multirow[t]{2}{*}{$\begin{array}{l}\text { Platform / } \\
\text { Effluent }\end{array}$} & \multicolumn{2}{|c|}{$\begin{array}{l}\text { Acartia tonsa } \\
\text { LC50 }\end{array}$} & \multicolumn{2}{|c|}{$\begin{array}{l}\text { Skeletonema costatum } \\
\text { EC50 }\end{array}$} & \multicolumn{2}{|c|}{$\begin{array}{l}\text { Vibrio fischeri } \\
\text { EC50 }\end{array}$} & \multirow{2}{*}{$\begin{array}{l}\text { WET based } \\
\text { HC50 } \\
\text { Dil. factor }\end{array}$} \\
\hline & Percent & Dil. factor & Percent & Dil. factor & Percent & Dil. factor & \\
\hline Alvheim & $32 \%$ & 3.1 & $14 \%$ & 7.1 & $13.7 \%$ & 7.3 & 5.4 \\
\hline Balder & $23 \%$ & 4.3 & $12.9 \%$ & 7.8 & $25.8 \%$ & 3.9 & 5.1 \\
\hline Brage & $5.3 \%$ & 18.9 & $11 \%$ & 9.1 & $5.4 \%$ & 18.5 & 14.7 \\
\hline Draugen & $66 \%$ & 1.5 & $12.8 \%$ & 7.8 & $43.5 \%$ & 2.3 & 3.0 \\
\hline Ekofisk J & $6.9 \%$ & 14.5 & $3.8 \%$ & 26.3 & $5.6 \%$ & 17.9 & 19.0 \\
\hline Ekofisk M & $15 \%$ & 6.7 & $8.2 \%$ & 12.2 & $5.2 \%$ & 19.2 & 11.6 \\
\hline Grane & $30 \%$ & 3.3 & $19 \%$ & 5.3 & $15.4 \%$ & 6.5 & 4.8 \\
\hline Gullfaks A & $1.7 \%$ & 58.8 & $<1.0 \%$ & $>100$ & $2.3 \%$ & 43.5 & 80.0 \\
\hline Gullfaks B & $47 \%$ & 2.1 & $1.7 \%$ & 58.8 & $12.9 \%$ & 7.8 & 9.9 \\
\hline Gullfaks C & $3.5 \%$ & 28.6 & $<1.0 \%$ & $>100$ & $1.8 \%$ & 55.6 & 68.3 \\
\hline Heidrun & $5.0 \%$ & 20 & $4.8 \%$ & 20.8 & $6.0 \%$ & 16.7 & 19.1 \\
\hline Jotun & $3.0 \%$ & 33.3 & $2.8 \%$ & 35.7 & $8.1 \%$ & 12.3 & 24.5 \\
\hline Knarr & $9.3 \%$ & 10.8 & $4.1 \%$ & 24.4 & $5.6 \%$ & 17.9 & 16.8 \\
\hline Norne & $4.9 \%$ & 20.4 & $1.8 \%$ & 55.6 & $3.3 \%$ & 30.3 & 32.5 \\
\hline Skarv & $9.1 \%$ & 11 & $12.1 \%$ & 8.3 & $13.6 \%$ & 7.4 & 8.8 \\
\hline Snorre A & $10 \%$ & 10 & $1.5 \%$ & 66.7 & $5.4 \%$ & 18.5 & 23.1 \\
\hline Snorre B & $5.5 \%$ & 18.2 & $5.3 \%$ & 18.9 & $12.5 \%$ & 8.0 & 14.0 \\
\hline Statfjord A & $6.1 \%$ & 16.4 & $7.0 \%$ & 14.3 & $8.2 \%$ & 12.2 & 14.2 \\
\hline Statfjord B & $5.8 \%$ & 17.2 & $1.5 \%$ & 66.7 & $4.1 \%$ & 24.4 & 30.4 \\
\hline Statfjord C & $3.8 \%$ & 26.3 & $<1.0 \%$ & $>100$ & $1.4 \%$ & 71.4 & 72.1 \\
\hline Troll B & $13 \%$ & 7.7 & $14.3 \%$ & 7.0 & $17.1 \%$ & 5.8 & 6.8 \\
\hline Troll C & $32.7 \%$ & 3.1 & $12.2 \%$ & 8.2 & $17.9 \%$ & 5.6 & 5.2 \\
\hline Ula & $29 \%$ & 3.4 & $4.6 \%$ & 21.7 & $21.2 \%$ & 4.7 & 7.0 \\
\hline Valhall & $4.0 \%$ & 25 & $6.4 \%$ & 15.6 & $15 \%$ & 6.7 & 13.8 \\
\hline Veslefrikk & $24 \%$ & 4.2 & $<1.0 \%$ & $>100$ & $3.9 \%$ & 25.6 & 27.8 \\
\hline
\end{tabular}

\subsection{Collecting and selecting toxicological data for the Substance Based hazard}

\subsubsection{Algae and crustacea}

The full list of selected tests and effect concentrations selected from the US EPA ECOTOX database is given in Annex 2. Table 4 summarises the toxicity tests that were selected for the SB calculations. In 
many cases, there was no data available for the species specifically tested in the WET tests. In those cases, surrogate species had to be used. In some cases, freshwater test data was also included.

Table 4. A summary of the algae and crustacea toxicity data selected from the EPA ECOTOX database. The column FW shows the number of freshwater (FW) tests selected. SW shows the number of saltwater (SW) tests selected. When the target species (i.e., the species tested in the WET tests: $S$. costatum and $A$. tonsa) are in the selection, this is marked with an $\mathrm{X}$.

\begin{tabular}{|c|c|c|c|c|c|c|c|c|}
\hline \multirow[b]{2}{*}{ EIF group } & \multicolumn{4}{|c|}{ Algae } & \multicolumn{4}{|c|}{ Crustacea } \\
\hline & $\begin{array}{l}\text { Exposure } \\
\text { duration } \\
\text { (h) }\end{array}$ & FW & sw & $\begin{array}{l}\text { Target species in } \\
\text { selection }\end{array}$ & $\begin{array}{l}\text { Exposure } \\
\text { duration } \\
\text { (h) }\end{array}$ & FW & sw & $\begin{array}{l}\text { Target species in } \\
\text { selection }\end{array}$ \\
\hline $\begin{array}{l}\text { Aliphatic } \\
\text { hydrocarbons }\end{array}$ & 8 & & 1 & & $24-96$ & 2 & & \\
\hline BTEX & $24-96$ & & 4 & $x$ & $24-96$ & 4 & 6 & \\
\hline Naphthalenes & 24 & & 1 & & $24-96$ & & 4 & \\
\hline PAH 2-3 ring & $24-96$ & & 4 & $x$ & $48-96$ & & 8 & \\
\hline PAH 4+ ring & 72 & & 1 & $x$ & 48 & & 4 & \\
\hline Phenol C0-C3 & 120 & & 2 & $x$ & $24-96$ & & 6 & \\
\hline Phenol C4-C5 & 72 & 1 & & & 96 & & 1 & \\
\hline Phenol C6+ & 72 & & 1 & $x$ & 48 & & 1 & $x$ \\
\hline Organic acid & $24-96$ & 6 & & & $1-336$ & 41 & 32 & \\
\hline Arsenic & 96 & 6 & & & 96 & & 2 & \\
\hline Cadmium & 72 & & 1 & $x$ & 96 & & 9 & $x$ \\
\hline Chromium & $48-72$ & & 5 & & 48 & & 6 & \\
\hline Copper & 72 & & 1 & $x$ & 48 & & 1 & $x$ \\
\hline Lead & 72 & & 1 & $x$ & 96 & & 2 & \\
\hline Mercury & 48 & & 10 & & $48-96$ & & 9 & $x$ \\
\hline Nickel & 48 & & 10 & & $96-96$ & & 1 & \\
\hline Zinc & 72 & & 1 & $x$ & 24 & & 1 & \\
\hline $\begin{array}{l}\text { Monoethylene } \\
\text { Glycol } \\
\text { (PLONOR) }\end{array}$ & 72 & & 1 & $x$ & $24-48$ & 31 & & \\
\hline $\begin{array}{l}\text { Methanol } \\
\text { (PLONOR) }\end{array}$ & 96 & & 1 & $x$ & 96 & & 2 & \\
\hline
\end{tabular}

A summary of effect concentrations (EC50/LC50s), as used in the hazard calculations, are listed in Table 5. Specific criteria used for the selection of effect concentrations are listed in Table 7.1 (Annex 7) of the 'methods' section.

Organic acids were also included in the present study. They are a complicated group as they can cause baseline toxicity as well as effect caused by changes in acidity. In the WET tests, the acidity of samples was generally neutralised, and effects of changes in acidity were therefore not measured. Whether the collected toxicity data studies also neutralised their samples, or performed in $\mathrm{pH}$ buffered media, was not clear. The data was included nonetheless, possibly overestimating the effects of organic acids. 
Table 5. EIF substance groups and geometric means of the $50 \%$ effect concentrations (EC50/LC50s) for relevant algae and crustacea, as selected from the US EPA ECOTOX database. The number of records $(N)$ on which it is based is also given as well as the standard deviation of the log10 transformed data.

\begin{tabular}{|c|c|c|c|c|c|c|c|c|}
\hline \multirow{2}{*}{ EIF group } & \multicolumn{4}{|c|}{ Algae } & \multicolumn{4}{|c|}{ Crustacea } \\
\hline & $\begin{array}{l}\text { Geo. Mean } \\
\text { EC50 } \\
\text { ( } \text { mol/L) }\end{array}$ & $\mathbf{N}$ & $\begin{array}{l}\text { St. dev. } \\
(\log 10)\end{array}$ & $\begin{array}{l}\text { Geo. } \\
\text { Mean } \\
\text { EC50 } \\
(\mathrm{mg} / \mathrm{L})\end{array}$ & $\begin{array}{l}\text { Geomean } \\
\text { EC50 } \\
(\mu \mathrm{mol} / \mathrm{L})\end{array}$ & $\mathbf{N}$ & $\begin{array}{l}\text { St. dev. } \\
(\log 10)\end{array}$ & $\begin{array}{l}\text { Geo. Mean } \\
\text { LC50/EC50 } \\
(\mathrm{mg} / \mathrm{L})\end{array}$ \\
\hline BTEX & 65.0 & 4 & 0.100 & 6.9 & 1057 & 10 & 0.552 & 77.5 \\
\hline Naphthalenes & 15.6 & 1 & - & 0.87 & 19.9 & 4 & 0.536 & 2.8 \\
\hline $\begin{array}{l}\text { Aliphatic } \\
\text { hydrocarbons }\end{array}$ & 15.0 & 1 & - & 1.50 & 641 & 2 & 0.154 & 64.2 \\
\hline PAH 2-3 ring & 4.59 & 4 & 0.174 & 0.707 & 6.35 & 8 & 0.454 & 1.11 \\
\hline $\mathrm{PAH} 4+$ ring & 204 & 1 & - & 41.3 & 2.13 & 4 & 0.976 & 0.431 \\
\hline Phenol C0-C3 & 528 & 2 & 0.00124 & 49.7 & 394 & 6 & 0.385 & 37.1 \\
\hline Phenol C4-C5 & 15.8 & 1 & - & 2.60 & 146 & 1 & - & 22.0 \\
\hline Phenol C6+ & 0.679 & 1 & - & 0.140 & 2.04 & 1 & - & 0.420 \\
\hline Organic acids & $1.22 \times 10^{3}$ & 2 & $0.002 \times 10^{3}$ & 73.6 & $3.08 \times 10^{3}$ & 31 & $0.70 \times 10^{3}$ & 211 \\
\hline Arsenic & 17.9 & 6 & 1.12 & 1.34 & 6.78 & 2 & 0 & 0.508 \\
\hline Cadmium & 1.28 & 1 & - & 0.144 & 1.27 & 9 & 0.341 & 0.142 \\
\hline Chromium & 11.6 & 5 & 0.414 & 0.601 & 264 & 6 & 0.128 & 13.7 \\
\hline Copper & 3.90 & 1 & - & 0.248 & 1.71 & 1 & - & 0.109 \\
\hline Lead & 0.0941 & 1 & - & 0.0195 & 3.22 & 2 & 0 & 0.668 \\
\hline Mercury & 0.386 & 10 & 0.324 & 0.0774 & 0.0762 & 9 & 0.0887 & 0.0153 \\
\hline Nickel & 41.0 & 10 & 0.834 & 2.4 & 102 & 1 & - & 6.0 \\
\hline Zinc & 2.17 & 1 & - & 0.142 & 28.4 & 1 & - & 1.86 \\
\hline $\begin{array}{l}\text { Monoethylene } \\
\text { Glycol (PLONOR) }\end{array}$ & $4.82 \times 10^{5}$ & $1^{4}$ & - & $2.99 \times 10^{4}$ & $4.73 \times 10^{5}$ & 31 & - & $2.94 \times 10^{4}$ \\
\hline Methanol (PLONOR) & $3.12 \times 10^{5}$ & 1 & - & $1.0 \times 10^{4}$ & $3.75 \times 10^{5}$ & 2 & 0 & $1.2 \times 10^{4}$ \\
\hline
\end{tabular}

The toxicity of the substances were important parameters for estimating the SB hazard. For most substance groups there was only a handful of specific acute toxicity data available. To get an impression of the certainty of the toxicity estimates a non-exhaustive comparison was made between the PAH (including naphthalene) data collected in the present study and data reported by RIVM (Verbruggen, 2012). Compared to that source, the EC50 value used in the present study were either in the same range or differed no more than a factor 2 when compared to the ranges reported by RIVM (Annex 8). An exception is formed by the algal toxicity of the 4-ring PAHs, where the EC50 value used in the present study is approximately a factor 800 larger than the range reported by RIVM (which contains non-target species). The study by RIVM also shows differences between specific substances, that will no longer be visible when they are grouped, as is done in the present study. This shows (at least for the PAHs) that the toxicity for the individual substances are considerable and using only a handful of data maybe more accurate (for the present purpose) but can also generate uncertainty.

\footnotetext{
${ }^{4}$ No data from the US EPA ECOTOX database available for algae for this substance. Information from an informal source was used: Preliminary data summary airport deicing operations (revised); EPA; https://books.google.nl/books?id=MPpIU17g1EsC\&pg=SA9PA51\&lpg=SA9-PA51\&dq=ward+1992+Skeletonema+costatum+Mysidopsis+bahia\&source=bl\&ots=6mgLe_OVi\&sig=MpQcDd11fFAyNsPFwBcs1U9uJc\&hl=en\&sa=X\&ved=0ahUKEwjV_bHR1NvWAhWOb1AKHcfpAVIQ6AEINjAF\#v=onepage\&q=29\%2C900\&f=false
} 


\subsubsection{Bacteria}

A complete list of effect concentrations as was collected for bacteria from the ECETOC EAT database is given in Annex 3. A summary of these effect concentrations, as was used in the hazard calculations, supplemented with ICE estimates are listed in Table 6.

Table 6. $\quad$ EIF substances and geometric means of the bacterial EC50 values. Based on either the ECETOC EAT 5 database or on the ICE relationship. Values are shown in both $\mu \mathrm{mol} / \mathrm{L}$ and $\mathrm{mg} / \mathrm{L}$ (the first are used in calculations).

\begin{tabular}{llll}
\hline EIF Group & Geo. mean EC50 ( $1 \mathrm{~mol} / \mathrm{L})$ & Geo. mean EC50 $(\mathrm{mg} / \mathrm{L})$ & Source \\
BTEX & 285 & 26.0 & ECETOC \\
\hline Naphthalenes & 9001 & $1.15 \times 10^{3}$ & ECETOC \\
\hline Aliphatic hydrocarbons & 10.7 & 1.07 & ICE \\
\hline PAH 2-3 ring & 4.68 & 0.72 & ICE \\
\hline PAH 4+ ring & 67.2 & 13.6 & ICE \\
\hline Phenol C0-C3 & 271 & 25.5 & ECETOC \\
\hline Phenol C4-C5 & 11.2 & 1.84 & ICE \\
\hline Phenol C6+ & 1.23 & 0.25 & ICE \\
\hline Organic acids & 174 & 10.9 & ECETOC \\
\hline Arsenic & 12.2 & 0.91 & ICE \\
\hline Cadmium & 257 & 28.9 & ECETOC \\
\hline Chromium & 565 & 29.4 & ECETOC \\
\hline Copper & 14.9 & 0.95 & ECETOC \\
\hline Lead & 0.675 & 0.14 & ECETOC \\
\hline Mercury & 0.598 & 0.12 & ECETOC \\
\hline Nickel & 21.8 & 1.28 & ICE \\
\hline Zinc & 378 & 24.7 & ECETOC \\
\hline Monoethylene Glycol & $1.81 \times 10^{6}$ & $1.12 \times 10^{5}$ & ECETOC \\
(PLONOR) & $1.29 \times 10^{6}$ & $4.13 \times 10^{4}$ & \\
\hline Methanol (PLONOR) & & & ECETOC \\
\hline & & & \\
\hline
\end{tabular}

Note that for bacteria the EC50 concentrations of the PAHs (including naphthalenes) were also compared to those of an additional source (Loibner et al., 2004 and Verbruggen, 2012). The EC50 value of naphthalenes used in the present study were much larger (nearly a factor $10^{3}$ ) than that of Loibner et al. (2004) and Verbruggen (2012). The 2-3 ring PAHs were in the same range, and the 4ring PAHs were not reported by Loibner et al. (2004). Detailed results are presented in Annex 8. 


\subsection{Calculating Substance Based Hazard}

Figure 2, Figure 3, Figure 4, Figure 5 and Figure 6 show the sum of Toxic Units (TU)s as were calculated for the substance groups used in this study for each platform. Platforms are displayed in alphabetical order in these plots and are distributed over 5 pages. The height of the bars in the figures gives an indication of the magnitude by which they contribute to the overall hazard for a platform. Note that in these figures, the $y$-scale is different in each panel (they are scaled to the maximum TU shown in each panel of the figures). In reality, the relationship is a bit more complicated as described in section 2.3.

For most platforms, the SB hazard is dominated by the combined group of production chemicals, the aliphatic hydrocarbons or the organic acids. Figure 2 up to Figure 6 only show the results for option 1 that includes production chemicals based on estimates for the sampling day for WET testing. For the options 2 and 3, with added chemical concentration estimates for the sampling month and sampling year, respectively the dominant substance group may shift from -or to- group of production chemicals (when compared to option 1). When production chemicals were omitted (option 4) the dominant group was either the aliphatic hydrocarbons or the organic acids. A complete tabular overview of calculated TUs all substance groups for all options of each platform (with numerical values), is listed in Annex 5.

Note that in the present study the toxicity of both these groups (aliphatic hydrocarbons and organic acids) may have been overestimated. The first because it was represented by the relatively toxic heptane while aliphatic hydrocarbons (dispersed oil) are dominated by hydrocarbons with higher molecular weight, the latter because toxicity data may have included effects caused by changes in $\mathrm{pH}$. More in general, the selection of toxicity data intended to reflect the conditions of the WET tests well, resulting in narrow and limited availability of toxicity data. Consequently, the selection procedure improved the accuracy of the SB approach at the cost of precision. 

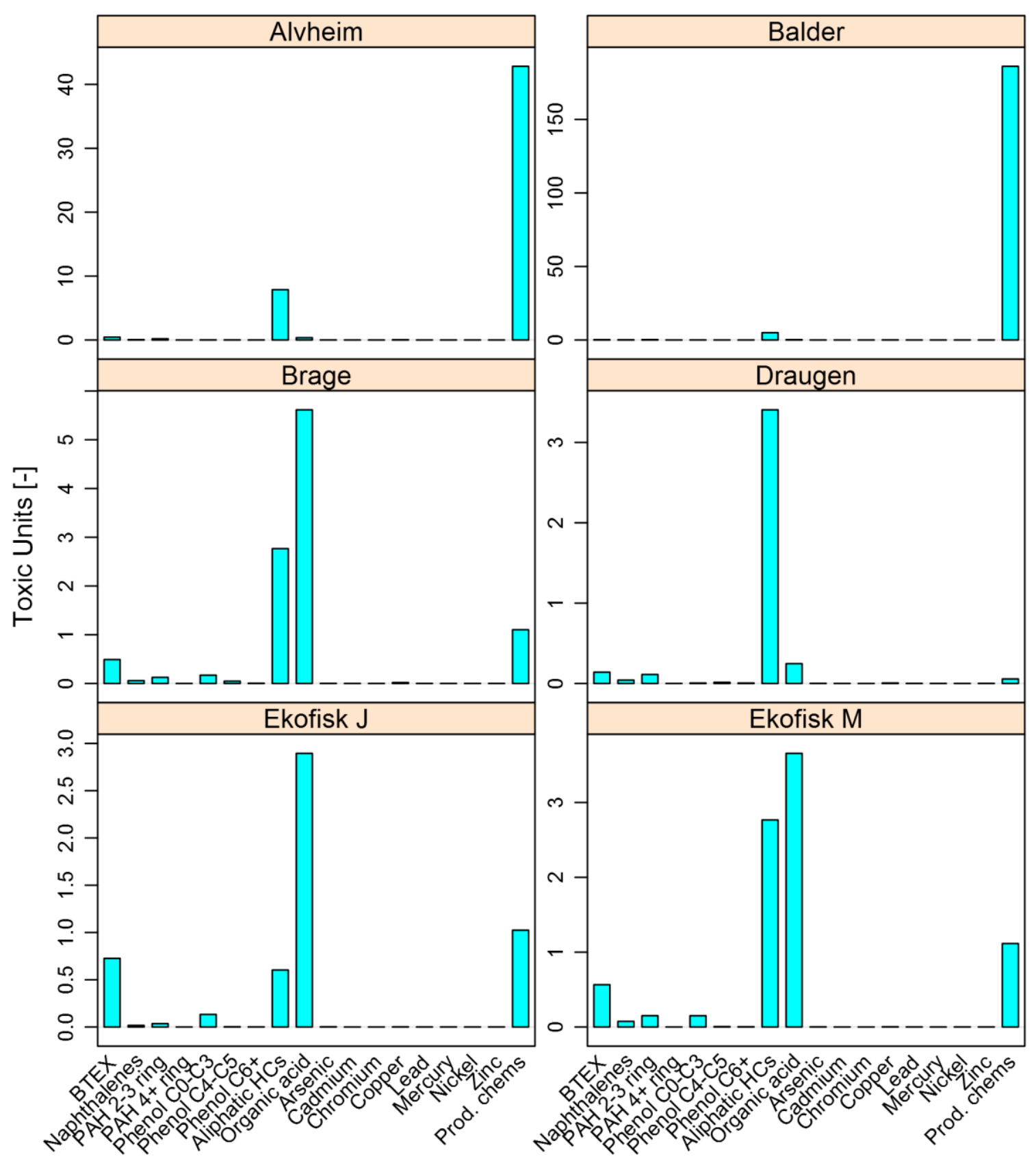

Figure 2. Platforms Alveim to Ekofisk M. Sum of toxic units (TUs) per EIF substance group, indicating relative contribution to total hazard. The production chemicals, organic acids and aliphatic hydrocarbons generally contribute most to the hazard per platform. Results shown are for option 1 (production chemicals based on best available information for the sampling day). 

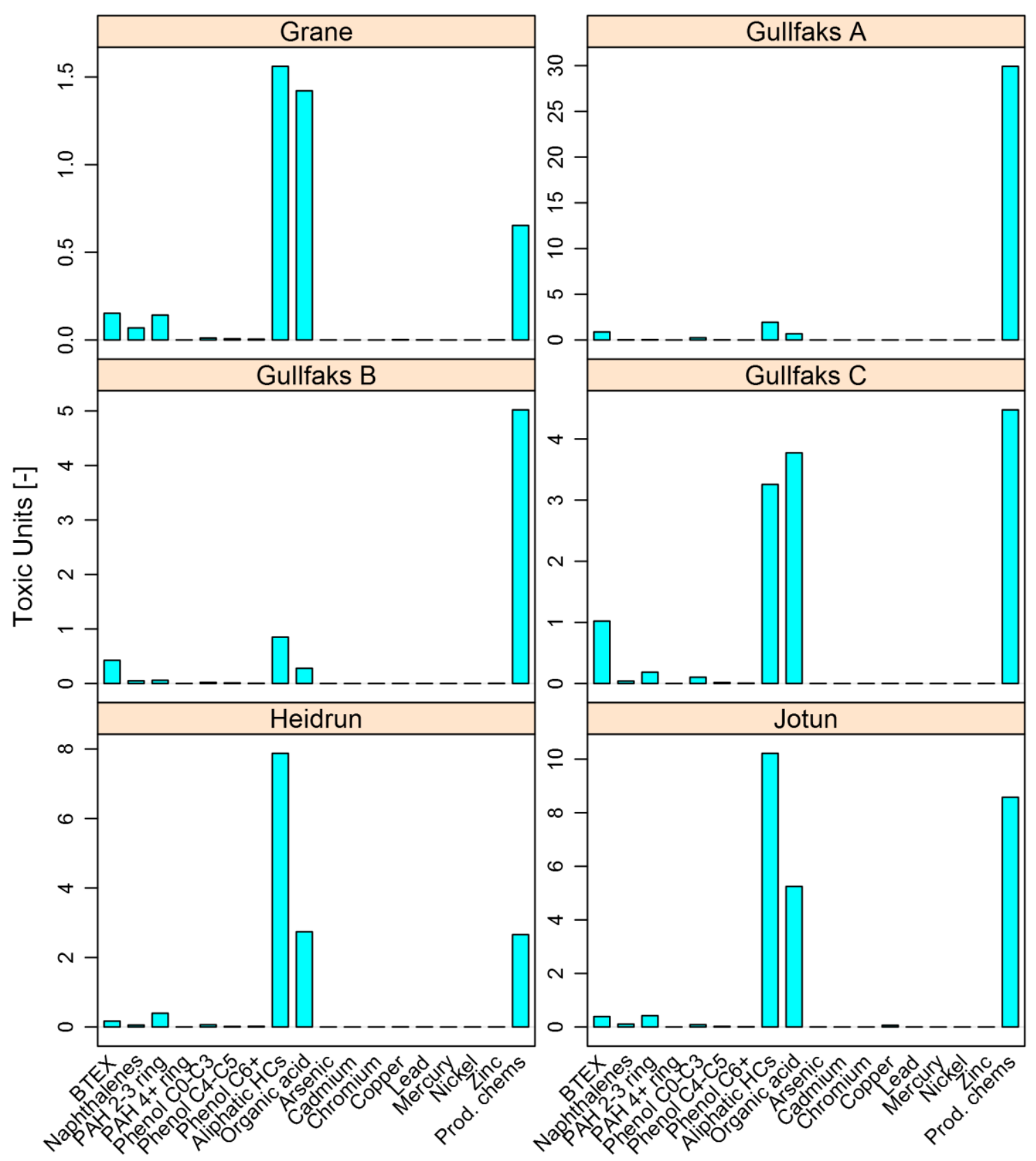

Figure 3. Platforms Grane to Jotun. Sum of toxic units (TUs) per EIF substance group, indicating relative contribution to total hazard. The production chemicals, organic acids and aliphatic hydrocarbons generally contribute most to the hazard per platform. Results shown are for option 1 (production chemicals based on best available information for the sampling day). 


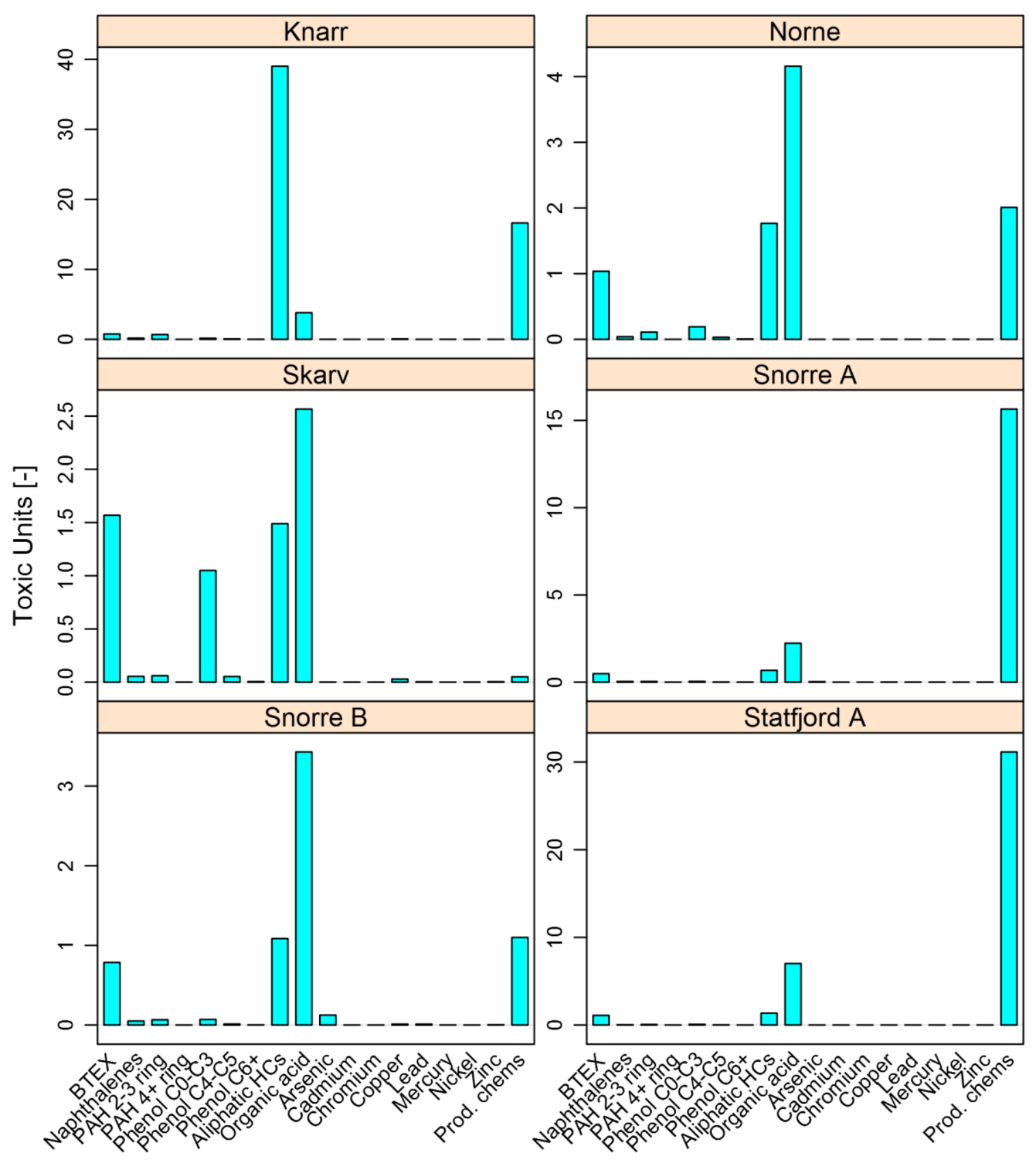

Figure 4. Platforms Knarr to Statfjord A. Sum of toxic units (TUs) per EIF substance group, indicating relative contribution to total hazard. The production chemicals, organic acids and aliphatic hydrocarbons generally contribute most to the hazard per platform. Results shown are for option 1 (production chemicals based on best available information for the sampling day). 

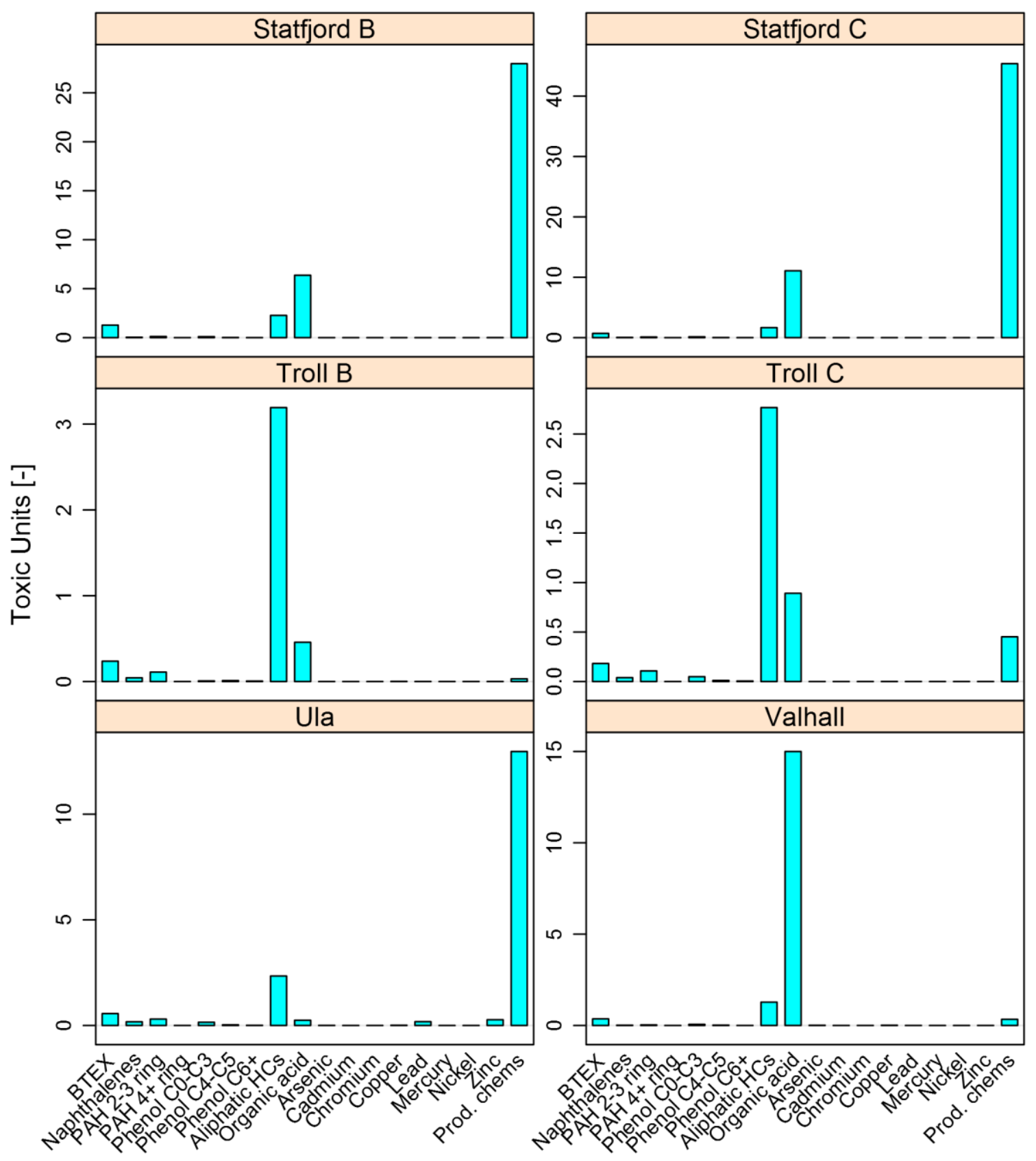

Figure 5. Platforms Statfjord B to Valhall. Sum of toxic units (TUs) per EIF substance group, indicating relative contribution to total hazard. The production chemicals, organic acids and aliphatic hydrocarbons generally contribute most to the hazard per platform. Results shown are for option 1 (production chemicals based on best available information for the sampling day). 


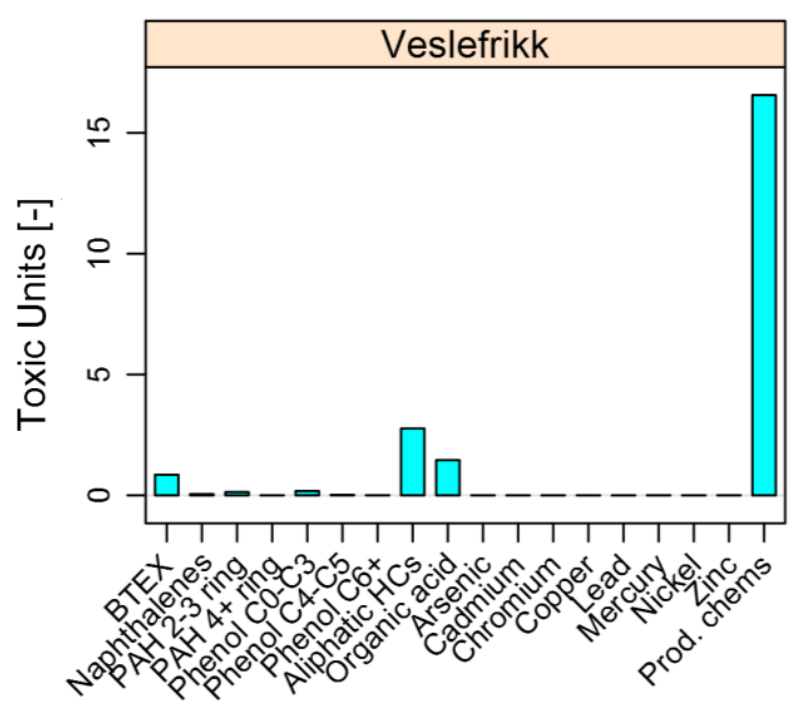

Figure 6. Platform Veslefrikk. Sum of toxic units (TUs) per EIF substance group, indicating relative contribution to total hazard. The production chemicals, organic acids and aliphatic hydrocarbons generally contribute most to the hazard per platform. Results shown are for option 1 (production chemicals based on best available information for the sampling day).

These TUs were used to calculate the HC50, which was used as a hazard indicator, as explained in the 'methods' section. The SB HC50 values are presented in the following sections where they are compared with the WET based HC50 values.

\subsection{Comparing Substance with WET Based Hazard}

\subsubsection{Visual presentation}

Figure 7, Figure 8, Figure 9 and Figure 10 show the hazard curves (SSDs) based on the WET tests and the SB approach. Where for the latter, several options for considering discharge concentrations of added production chemicals in the PW effluent were used; including: 1 . Best discharge estimate at the day of sampling for WET; 2 . Average discharge concentration in the month of sampling for WET; 3. Annual average discharge concentration; 4 . No chemicals included in the discharge.

From the WET based SSDs (Figure 7, Figure 8, Figure 9 and Figure 10) the most sensitive species was identified. The most sensitive species are located at the lowest PAF (near the bottom) in these plots, indicating that more dilution is required to reach their $50 \%$ effect concentration (EC50). It can be seen that the algae (S. costatum shown with circles) are the most sensitive species for the effluent of most platforms ( 17 out of the 25 effluents), followed by the crustacean ( $A$. tonsa shown by squares) ( 5 out of the 25 effluents) and bacteria ( $V$. fischeri shown by triangles) ( 3 out of the 25 effluents). The slope of the WET based SSD curves show variation among the platforms. For instance, the slopes for the curves of Gullfaks B and Veslefrikk are very shallow (low Sm values, high variation in species sensitivity), while those of Skarv and Knarr are very steep (high Sm value, low variation in species sensitivity). This suggests that not only the sensitivity itself is affected by the effluent, but also the variation in sensitivity among species is affected by the effluent and its chemical composition. 


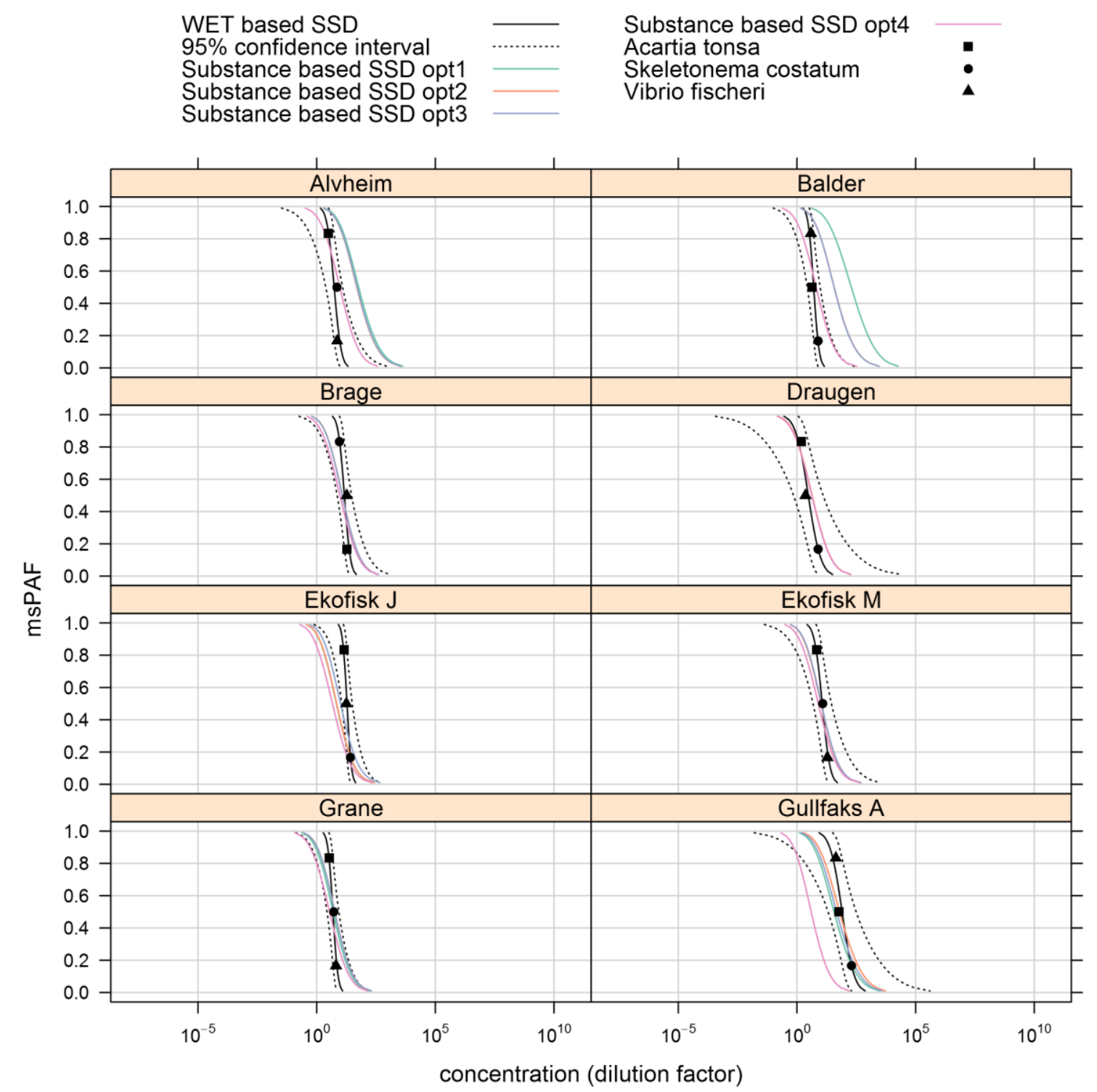

Figure 7. $\quad$ Platforms part 1. Species Sensitivity Distribution (SSD) curves (or hazard curves) based on the WET tests (in black) and based on the substance characterisation (coloured lines). msPAF denotes the hazard expressed as multi-substance Potentially Affected Fraction. Note that the $x$-axis (logarithmic scale) is identical in all panels. Dotted lines indicate the 95\% confidence interval for the WET based approach calculated with the methodology described by Aldenberg et al. (2002). 


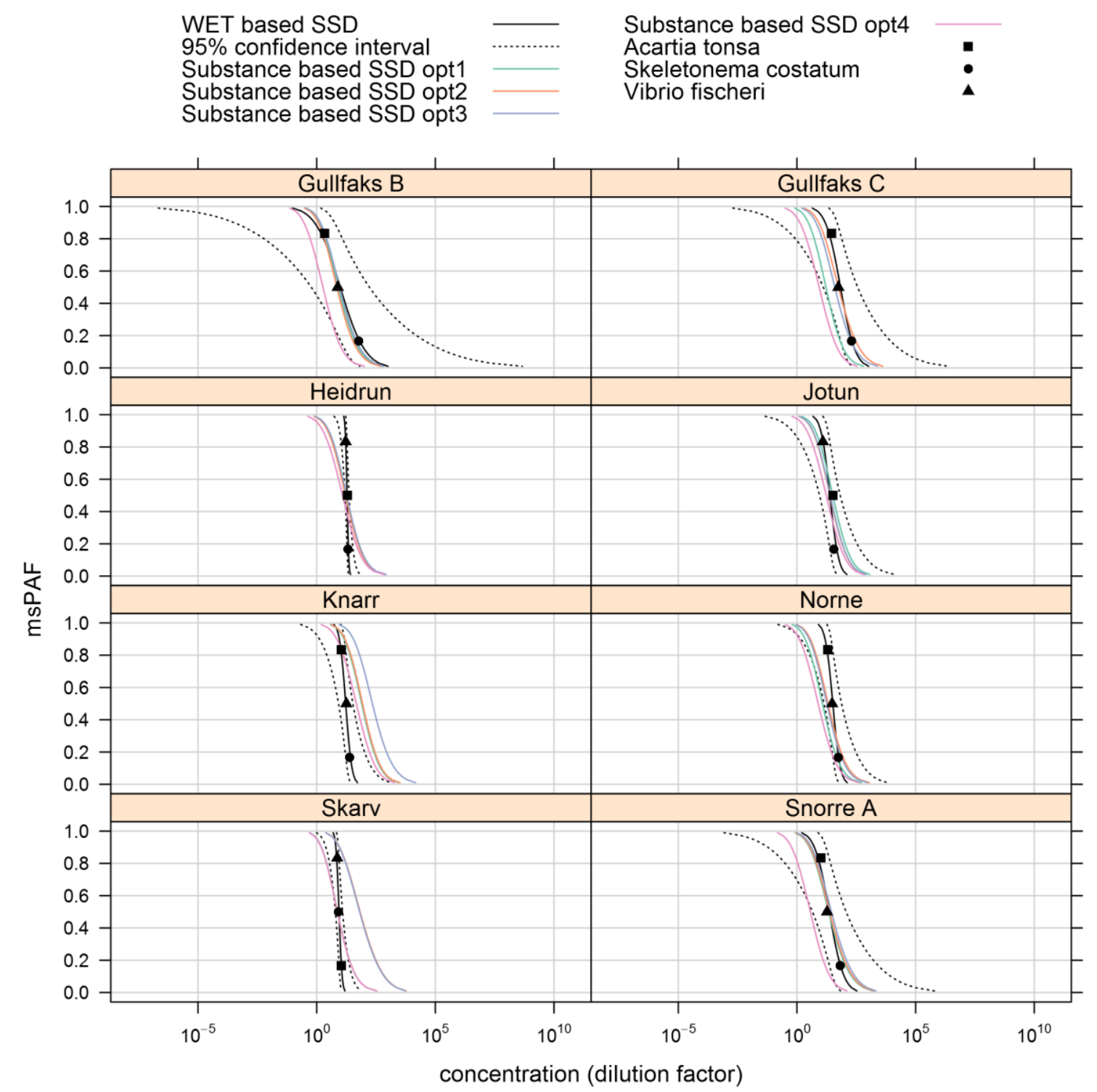

Figure 8. $\quad$ Platforms part 2. Species Sensitivity Distribution (SSD) curves (or hazard curves) based on the WET tests (in black) and based on the substance characterisation (coloured lines). msPAF denotes the hazard expressed as multi-substance Potentially Affected Fraction. Note that the $x$-axis (logarithmic scale) is identical in all panels. Dotted lines indicate the 95\% confidence interval for the WET based approach calculated with the methodology described by Aldenberg et al. (2002). 


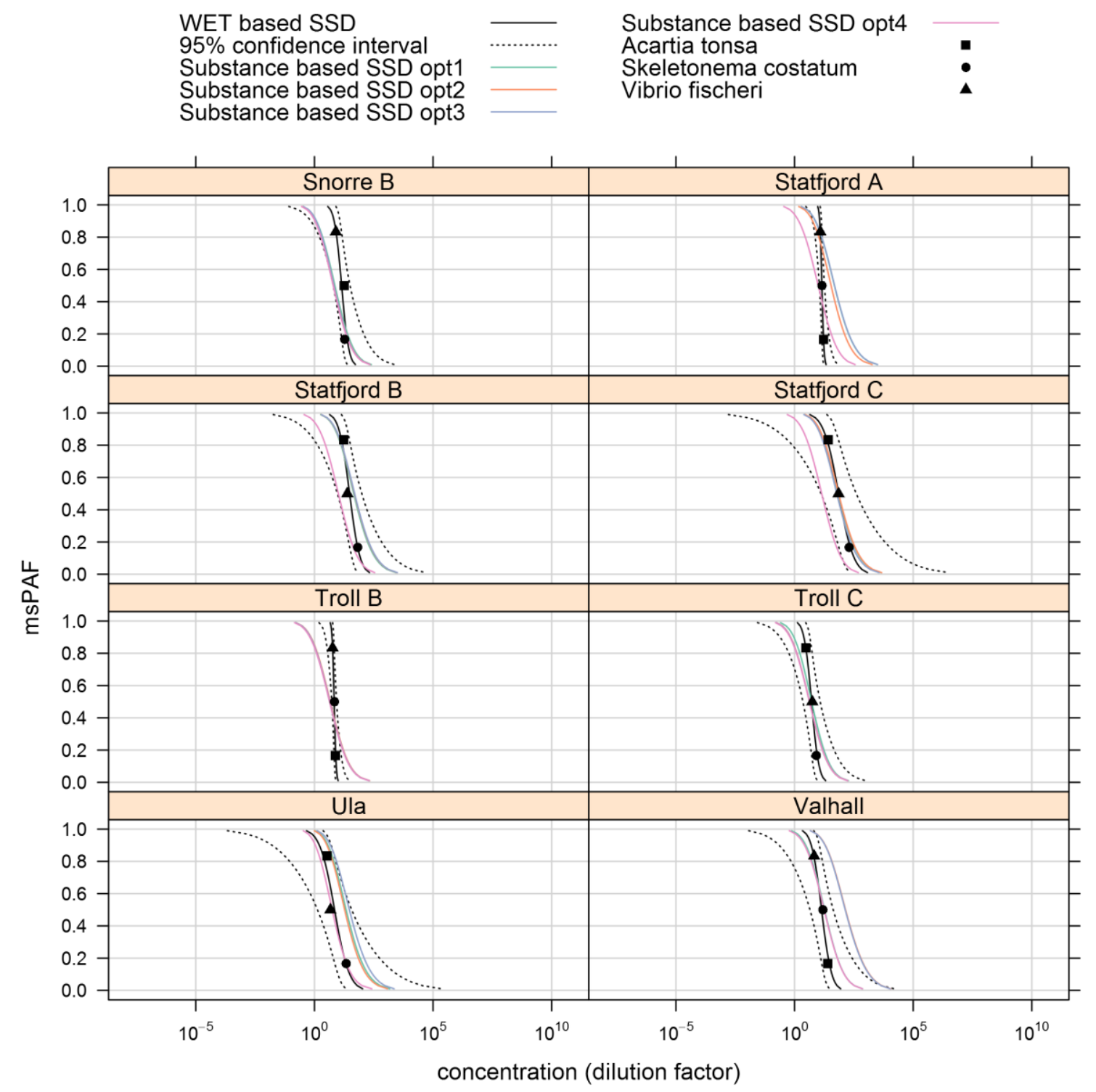

Figure 9. $\quad$ Platforms part 3. Species Sensitivity Distribution (SSD) curves (or hazard curves) based on the WET tests (in black) and based on the substance characterisation (coloured lines). msPAF denotes the hazard expressed as multi-substance Potentially Affected Fraction. Note that the $x$-axis (logarithmic scale) is identical in all panels. Dotted lines indicate the 95\% confidence interval for the WET based approach calculated with the methodology described by Aldenberg et al. (2002). 


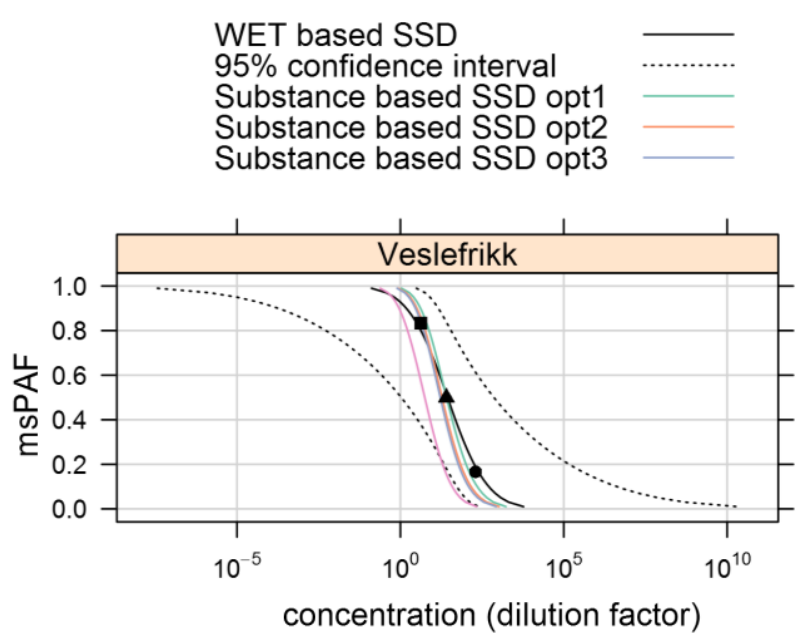

Substance based SSD opt4

Acartia tonsa

Skeletonema costatum

Vibrio fischeri

Figure 10. Platforms part 4. Species Sensitivity Distribution (SSD) curves (or hazard curves) based on the WET tests (in black) and based on the substance characterisation (coloured lines). msPAF denotes the hazard expressed as multi-substance Potentially Affected Fraction. Note that the $x$-axis (logarithmic scale) is identical in all panels. Dotted lines indicate the $95 \%$ confidence interval for the WET based approach calculated with the methodology described by Aldenberg et al. (2002).

The hazard SSD curves for both WET and the SB approach for all options are shown for all 25 platforms (25 effluents) in Figure 7 to Figure 9 . The $50 \%$ hazardous concentration (HC50) can have been determined for both the WET based and SB approach and corresponds with the concentration at which $\mathrm{PAF}=0.5$ in the SSDs presented above.

In Figure 11 the calculated $\mathrm{HC} 50$ values for both approaches are plotted against each other for all 4 options. The black diagonal line indicates the position of the WET and SB HC50 estimates, expressed as dilution factor of the effluent required to arrive at $\mathrm{HC50}$, when they are equal ( $\mathrm{y}=\mathrm{x}$ or in this specific case: $\mathrm{HC}_{\mathrm{SB}}=\mathrm{HC} 5 \mathrm{WWET}_{\mathrm{WET}}$ ). $\mathrm{HC5}$ estimates for platforms (blue dots in Figure 11) left of the solid black diagonal line indicate that the WET based approach results in more conservative (higher) hazard estimates than the SB approach. When the dots are situated on the right-hand side, the SB approach results in more conservative (higher) hazard estimates than the WET based approach.

Table 7 lists the numerical data for all the HC50 estimates, both SB and WET based. Added chemicals are included in the SB HC50 estimate for all options, except for option 4. The table also shows the ratio between the HC50 estimates (SB HC50 divided by the WET based HC50). When this ratio is larger than 1, the SB HC50 is more conservative than its WET based counterpart. The reverse is true when the ratio is less than 1 . The perpendicular distance for each sample to the line $y=x$ (or $\mathrm{HC50} \mathrm{SB}_{\mathrm{B}}=\mathrm{HC} 50_{\text {WET }}$ in this specific case) on a $\log _{10}-\log _{10}$ Scale, shown as the solid black diagonal line in Figure 11, is also listed in Table 7. When the distance is greater than 0 , the SB is more conservative than the WET based HC50. When the distance is less than 0 , the reverse is true.

For the Deming regression applied in Figure 11 (blue solid line), it is not possible nor meaningful to calculate correlation estimates. To get an impression, the following correlation estimates $\left(r^{2}\right.$ penalized for high $p$-values) are based on ordinary linear regression (not shown in Figure 11): option 1: 0.10; option 2: 0.01 ; option $3: 0.10$; option $4: 0.17$. Note that the correlation is poor in all cases (far from $\left.r^{2}=1\right)$. The correlation (albeit indicative and not based on Deming regression) appears to be best for option $4\left(r^{2}=0.17\right)$. Nonetheless the Deming regression line deviates most from the expected relation $(y=x)$ for that option (i.e., the blue solid line versus the black solid diagonal line respectively). The low correlations (based on the ordinary linear regression) suggests that uncertainty in HC50 estimates (for both the WET and the SB approach) are in the same order of magnitude as the variance among platforms. This observation is supported by the large error bars around the WET based hazard estimates (based on the limited number of WET tests and the shallow slope of the WET based SSD). Note that the uncertainty is not visualised for the SB hazard estimates. This does not mean that there is no uncertainty, it was however not possible to properly quantify the uncertainty for this approach. The low correlation means that there is either a low distinction between hazard of different effluents or that the SB and the WET based approach reflect different aspects of the hazard (or both). 


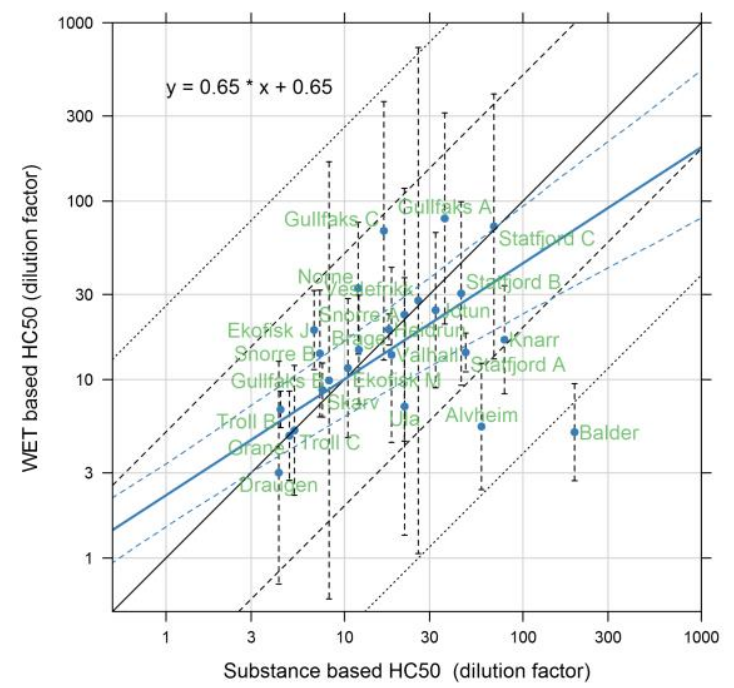

Option 1

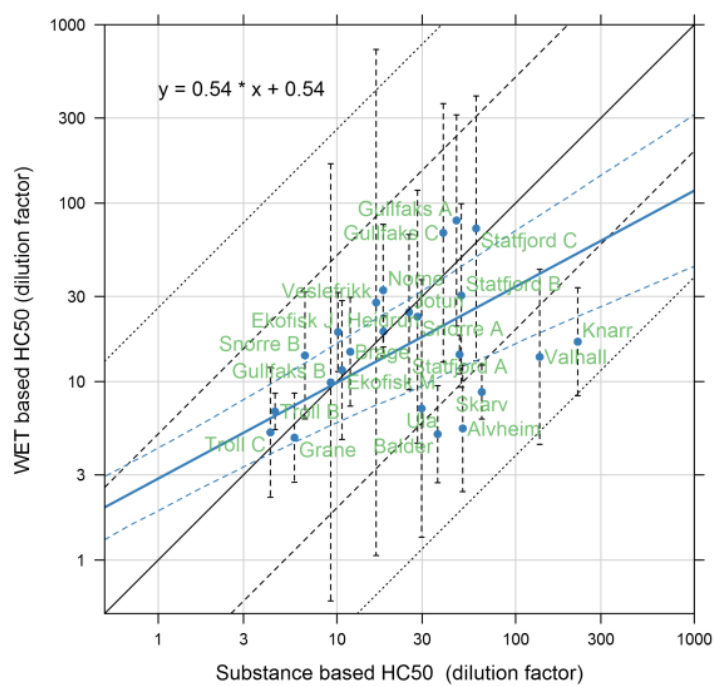

Option 3

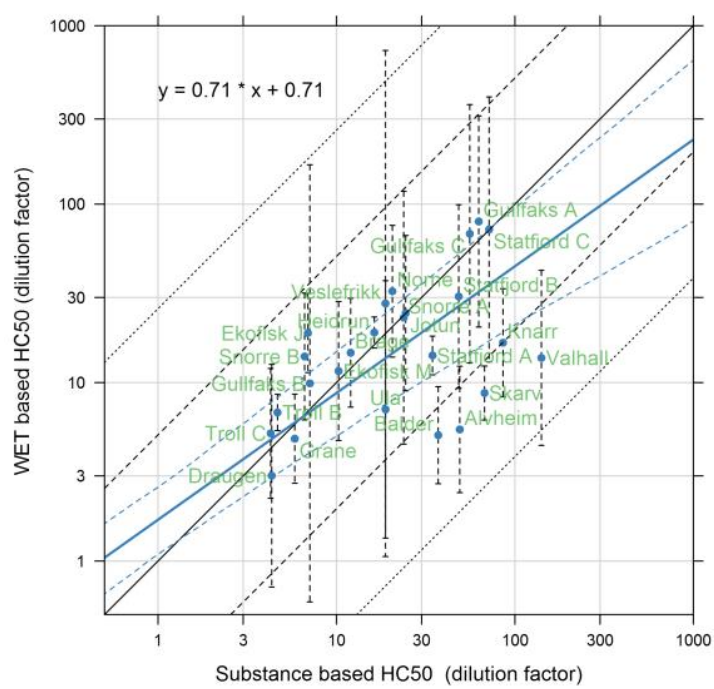

Option 2

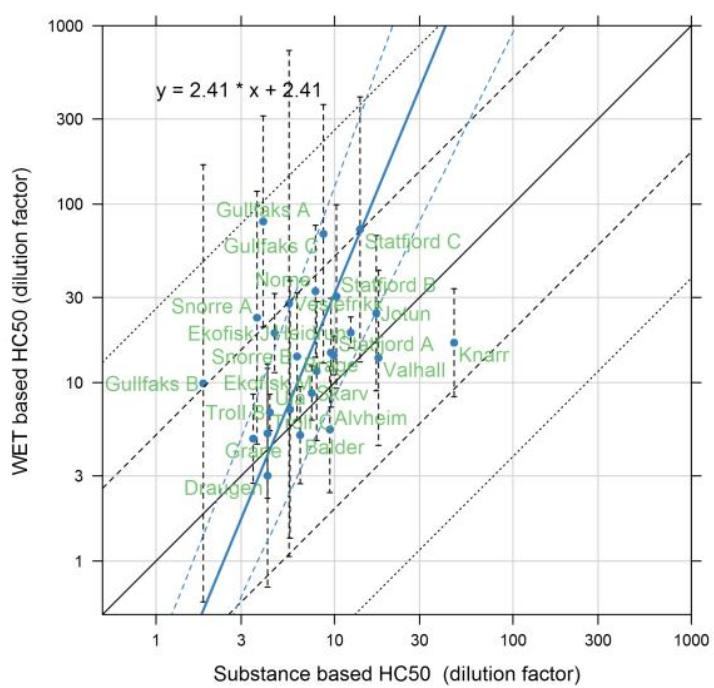

Option 4

Figure 11. 50\% Hazardous Concentrations (HC50) based on substance approach (x-axis) and WET approach (y-axis). Error bars in WET based HC50 indicate $95 \%$ confidence intervals using the methodology described by Aldenberg et al. (2002). SB HC50 uncertainty can hardly be quantified and are therefore not displayed. Solid black line indicates the 1:1 relationship. Dotted black lines indicate where WET based and SB HC50 only differ an order of magnitude (factor 10 in either direction), dashed lines indicate half an order of magnitude difference. Blue line shows the result of the Deming regression (equation resulting from the regression is shown in the top left corner, dashed blue lines show 95\% confidence intervals for the regression). Each panel shows a different option for including discharge concentration estimates for production chemicals (option 1, using daily estimates; option 2: monthly estimate; option 3: yearly estimates; option 4: production chemicals not included). 
Table 7. WET based and SB 50\% hazardous concentrations (HC50s) for all added chemical options expressed as dilution factors (e.g., a factor of 2 means that the effluent needs to be diluted with a factor of 2 , in order to reach a hazard where potentially $50 \%$ of the species are affected). The ratio between SB and WET based $\mathrm{HC50}\left(\frac{\mathrm{HC5}_{\text {substance }}}{\mathrm{HC50}_{\mathrm{WET}}}\right)$ is also given, as well as the perpendicular distance to the black diagonal line $(y=x)$ in Figure 11 described with equation: $\frac{1}{\sqrt{2}} \log _{10}\left(\frac{\mathrm{HC}_{\mathrm{S}} \mathrm{substance}_{\mathrm{H}}}{\mathrm{HC} 50_{\mathrm{WET}}}\right)$. Effluents where the SB HC50 for the different chemical options is more than twice as high (ratio $\geq 2$ ) as the WET based HC50 are marked blue (SB effluent options indicated with higher hazard than WET based approach). Effluents where the WET HC50 is more than twice as high (ratio $\leq 0.5$ ) as the SB HC50 are marked green (SB effluents options indicated with lower hazard than WET based approach). Effluents without any colour indication have HC50s that are similar $(0.5<$ ratio $<2)$.

\begin{tabular}{|c|c|c|c|c|c|c|c|c|c|c|c|c|c|}
\hline Platform & $\begin{array}{l}\text { 䎡 } \\
\text { o } \\
\text { 웅 }\end{array}$ & 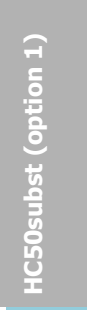 & 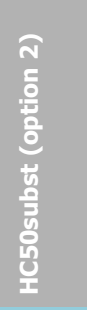 & 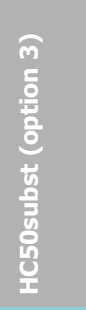 & 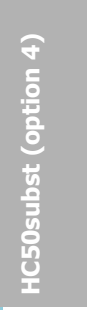 & 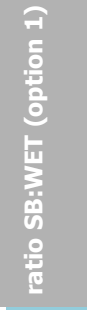 & 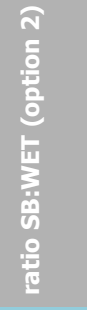 & 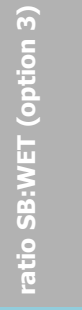 & 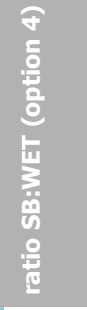 & 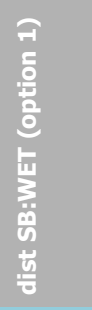 & 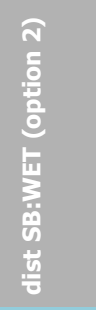 & 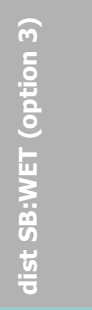 & 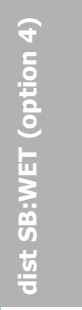 \\
\hline Alvheim & 5.46 & 58.6 & 49.1 & 50.6 & 9.42 & 10.7 & 8.99 & 9.26 & 1.72 & 0.73 & 0.67 & 0.68 & 0.17 \\
\hline Balder & 5.07 & 195 & 37.2 & 36.6 & 6.42 & 38.4 & 7.32 & 7.22 & 1.27 & 1.12 & 0.61 & 0.61 & 0.07 \\
\hline Brage & 14.7 & 12.0 & 12.0 & 11.9 & 9.55 & 0.82 & 0.82 & 0.81 & 0.65 & -0.06 & -0.06 & -0.07 & -0.13 \\
\hline Draugen & 3.01 & 4.29 & 4.34 & - & 4.22 & 1.42 & 1.44 & - & 1.40 & 0.11 & 0.11 & - & 0.10 \\
\hline Ekofisk J & 19.0 & 6.76 & 6.92 & 10.1 & 4.62 & 0.36 & 0.36 & 0.53 & 0.24 & -0.32 & -0.31 & -0.19 & -0.43 \\
\hline Ekofisk M & 11.6 & 10.5 & 10.3 & 10.7 & 7.94 & 0.90 & 0.89 & 0.92 & 0.68 & -0.03 & -0.04 & -0.03 & -0.12 \\
\hline Grane & 4.85 & 4.91 & 5.84 & 5.78 & 3.50 & 1.01 & 1.20 & 1.19 & 0.72 & 0.00 & 0.06 & 0.05 & -0.10 \\
\hline Gullfaks A & 80.0 & 36.5 & 62.7 & 46.7 & 3.98 & 0.46 & 0.78 & 0.58 & 0.05 & -0.24 & -0.07 & -0.17 & -0.92 \\
\hline Gullfaks B & 9.90 & 8.20 & 7.09 & 9.23 & 1.84 & 0.83 & 0.72 & 0.93 & 0.19 & -0.06 & -0.10 & -0.02 & -0.52 \\
\hline Gullfaks C & 68.2 & 16.6 & 55.8 & 39.4 & 8.67 & 0.24 & 0.82 & 0.58 & 0.13 & -0.43 & -0.06 & -0.17 & -0.63 \\
\hline Heidrun & 19.1 & 17.7 & 16.3 & 18.2 & 12.3 & 0.93 & 0.85 & 0.95 & 0.65 & -0.02 & -0.05 & -0.01 & -0.13 \\
\hline Jotun & 24.5 & 32.4 & 24.4 & 25.3 & 17.2 & 1.32 & 1.00 & 1.03 & 0.70 & 0.09 & 0.00 & 0.01 & -0.11 \\
\hline Knarr & 16.7 & 78.8 & 85.7 & 223 & 46.8 & 4.71 & 5.12 & 13.3 & 2.80 & 0.48 & 0.50 & 0.79 & 0.32 \\
\hline Norne & 32.5 & 11.9 & 20.6 & 18.1 & 7.83 & 0.37 & 0.63 & 0.56 & 0.24 & -0.31 & -0.14 & -0.18 & -0.44 \\
\hline Skarv & 8.74 & 7.53 & 67.6 & 64.7 & 7.46 & 0.86 & 7.73 & 7.40 & 0.85 & -0.05 & 0.63 & 0.61 & -0.05 \\
\hline Snorre A & 23.1 & 21.7 & 23.8 & 28.3 & 3.68 & 0.94 & 1.03 & 1.22 & 0.16 & -0.02 & 0.01 & 0.06 & -0.56 \\
\hline Snorre B & 14.0 & 7.28 & 6.63 & 6.62 & 6.17 & 0.52 & 0.47 & 0.47 & 0.44 & -0.20 & -0.23 & -0.23 & -0.25 \\
\hline Statfjord A & 14.2 & 47.8 & 34.5 & 48.6 & 9.89 & 3.37 & 2.43 & 3.42 & 0.70 & 0.37 & 0.27 & 0.38 & -0.11 \\
\hline Statfjord B & 30.5 & 45.1 & 48.4 & 49.7 & 10.3 & 1.48 & 1.59 & 1.63 & 0.34 & 0.12 & 0.14 & 0.15 & -0.33 \\
\hline Statfjord C & 72.2 & 68.8 & 71.7 & 60.1 & 13.9 & 0.95 & 0.99 & 0.83 & 0.19 & -0.01 & 0.00 & -0.06 & -0.51 \\
\hline Troll B & 6.80 & 4.38 & 4.67 & 4.51 & 4.34 & 0.64 & 0.69 & 0.66 & 0.64 & -0.13 & -0.12 & -0.13 & -0.14 \\
\hline Troll C & 5.19 & 5.24 & 4.28 & 4.24 & 4.21 & 1.01 & 0.82 & 0.82 & 0.81 & 0.00 & -0.06 & -0.06 & -0.06 \\
\hline Ula & 7.07 & 21.7 & 18.8 & 29.8 & 5.64 & 3.07 & 2.66 & 4.21 & 0.80 & 0.34 & 0.30 & 0.44 & -0.07 \\
\hline Valhall & 13.8 & 18.4 & 141 & 136 & 17.6 & 1.33 & 10.2 & 9.91 & 1.28 & 0.09 & 0.71 & 0.70 & 0.08 \\
\hline Veslefrikk & 27.8 & 25.9 & 18.8 & 16.6 & 5.56 & 0.93 & 0.68 & 0.60 & 0.20 & -0.02 & -0.12 & -0.16 & -0.49 \\
\hline
\end{tabular}

Despite the low correlations seen in Figure 11 (as widely scattered values and listed as correlation estimates in the main text above), HC50 values based on WET are very close (mostly less than an order of magnitude, i.e. a factor 10) to the SB HC50 values for most effluents for all chemical options (92-96\%) (Table 8). The WET based hazard is less frequently more conservative (higher HC50s) than the SB hazard for effluent options including added chemicals (option 1, 2 and 3) than for the effluent option 4 , excluding added chemicals ( 54 to $56 \%$ versus $80 \%$ of the effluents) (Table 8 ). This underlines that omitting production chemicals in the hazard calculation, clearly results in an underestimation of the SB hazard. 
Overall, the WET based approach more frequently predicts a higher hazard of the effluents than was estimated with the SB approach. Possible causes for a relatively low SB hazard are: the acute toxicity of one or more substances/EIF groups was estimated too low; not all potential toxic substances in the PW effluent were measured/included in the analysis (presence of "unknowns"); interaction between toxicants were not included correctly. The average difference between the WET based and SB approach is however very small and insignificant, as will be addressed later.

Table 8. Overview on how well the WET based HC50 corresponds with SB HC50 values for the different added chemical options. Percentages are the percentage of PW effluents $(N=25)$ for which the statement in the header is true.

\begin{tabular}{|c|c|c|c|}
\hline Production chemicals & $\begin{array}{l}\text { WET and SB hazard less than } \\
\text { an order (factor 10) of } \\
\text { magnitude difference }\end{array}$ & $\begin{array}{l}\text { WET and SB hazard less than } \\
\text { half an order (factor } 5 \text { ) of } \\
\text { magnitude difference }\end{array}$ & $\begin{array}{l}\text { WET based HC50 more } \\
\text { conservative than SB HC50 }\end{array}$ \\
\hline Opt. 1: Daily estimate & $92 \%$ & $80 \%$ & $56 \%$ \\
\hline Opt. 2: Monthly estimate & $96 \%$ & $80 \%$ & $56 \%$ \\
\hline Opt. 3: Yearly estimate & $96 \%$ & $71 \%$ & $54 \%$ \\
\hline Opt. 4: Chemicals excluded & $96 \%$ & $68 \%$ & $80 \%$ \\
\hline
\end{tabular}

In summary, the WET and SB hazard (expressed by HC50) based on the discharge profile for option 1 (day of sampling for WET) corresponded well for 16 out of the total 25 platforms (64\%), as the difference between the SB and WET based approach is less than a factor of 2 (Table 7). This is the case for platforms Brage, Draugen, Ekofisk M, Grane, Gullfaks B, Heidrun, Jotun, Skarv, Snorre A, Snorre B, Statfjord B, Statfjord C, Troll B, Troll C, Valhall and Veslefrikk. This percentage (64\%) is the same for the options 2 and 3 , although it covers different platforms. For option 4 (excluding production chemicals) only 14 out of the $25(56 \%)$ platforms show a difference of less than a factor of 2 between the SB and WET based approach.

For 4 out of the 25 platforms (16\%) the WET based hazard was more than a factor 2 higher (more conservative) than the SB hazard based on option 1: Ekofisk J, Gullfaks A, Gullfaks C and Norne. For option 2 this is only the case for two platforms (8\%): Ekofisk J and Snorre B, and for option 3 only Snorre B (4\%). For option 4 (excluding production chemicals) the WET based HC50 is more than a factor 2 higher than the SB HC50 for 10 out of the 25 platforms (40\%).

For 5 out of 25 platforms (20\%) the SB hazard was more than a factor 2 higher than the WET based hazard for option 1: Alvheim, Balder, Knarr, Statfjord A and Ula. This is also the case for options 2 and 3. However for options 2 and 3 there are 2 additional platforms (Valhall and Skarv), making a total of 7 out of $25(28 \%)$ or out of $24^{5}(29 \%$, in case of option 3$)$, where the SB hazard was more conservative (factor $\geq 2$ ) than the WET hazard. For option 4 this was only the case for platform Knarr $(4 \%)$.

Figure 12 shows the result of a cluster analysis for option 1, indicating where the contribution of specific EIF substance groups to the SB hazard is similar. The clustering differs for the different options of including production chemicals, where for each option some platforms will shift from one branch to another in the cluster tree (results not shown, this also follows from the principal component analysis presented below). The analysis shows that the chemical composition of many platforms is very similar (in particular platforms situated at the same oil field).

This is also why the closely related principal component analysis (PCA) was performed as explained in the methodology section (2.5.2.1). The first three principal components are shown in Annex 9. For the PCA, the outcome also depends on the option for including the production chemicals. Nonetheless, the first and most important principal component (PC1) is very similar for each of the options (Annex 9). In the first principal component (PC1, which is the component that explains most variance) the PAHs, naphthalenes and aliphatic hydrocarbons are grouped together. This means that the variation in composition of the effluent (in terms of TU) is mostly caused by these substances and that the levels of these substances are correlated. In other words, the composition of the effluent (in terms of TU) varies most for the PAHs and when concentrations of PAHs are relatively high, the same is true for the naphthalenes and aliphatic hydrocarbons. This means that any effects caused by this principal

\footnotetext{
${ }^{5}$ Note that for option 3 the Draugen installation was not included. Therefore, the total number of platforms equals 24 instead of 25 for this option.
} 
component (PC1) can be caused by any of the major contributors to this principal component (i.e. PAHs, naphthalenes or aliphatic hydrocarbons).

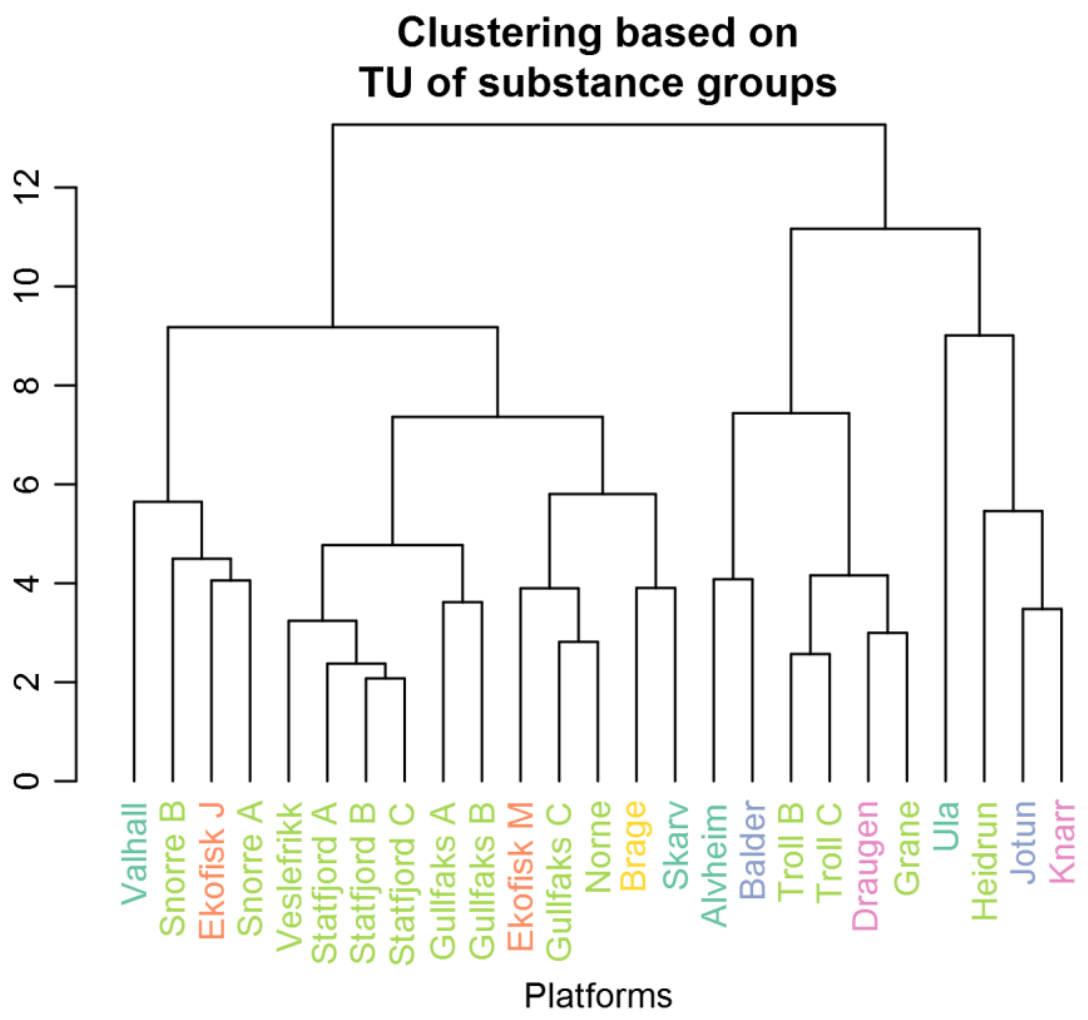

Figure 12. Cluster analyses based on ( $\log _{10}$ transformed) toxic units (TUs) of the substance groups. Only shown for option 1 (production chemicals based on estimates of day of sampling). Platforms where the hazard contribution from the different chemical groups is similar are clustered together (on the same branch of the tree). The height in the plot indicates the Euclidean distance between two branches (i.e., the larger the Euclidean distance / height, the larger the difference). Colours indicate the different operators associated with the installation.

When the cluster tree (Figure 12) is cut into three major branches at a height of 10, the first branch contains 15 platforms (on the left-hand side in Figure 12), whereas the second and third branch contain 6 and 4 platforms, respectively. The first branch contains a relatively large fraction of Equinor platforms (67\%, labelled bright green in Figure 12), when compared to the second and third branches (33\% and 7\%, respectively in Table 9). However, there is no evidence that Equinor is statistically overrepresented in the first branch ( $p=0.16$; Fisher's exact test for counting data). Consequently, there is no evidence that the chemical composition (or more accurately: the hazard composition expressed as TU) is associated with the operator.

Table 9. Distribution of operators among the branches of the cluster tree in Figure 12. The major three branches are cut off at a height of 10 in Figure 12.

\begin{tabular}{lllll} 
Equinor $(\mathrm{N})$ & Other $(\mathrm{N})$ & Equinor $(\%)$ & Other $(\%)$ & Branch \\
10 & 5 & $67 \%$ & $33 \%$ & 1 \\
\hline 2 & 4 & $33 \%$ & $67 \%$ & 2 \\
\hline 1 & 3 & $7 \%$ & $20 \%$ & 3 \\
\hline
\end{tabular}

\subsubsection{Statistical analysis}

The comparisons using the HC50 values only focuses on a single point on the hazard (SSD) curve. The Kolmogorov-Smirnov considers the vertical distance between WET based data and the SB SSD over the full range of the curve. Note that we here compared the distance of the WET based and SB Sshaped hazard curve, not to be confused with the distance between WET based and SB HC50 discussed above. 
Kolmogorov-Smirnov statistics, indicate the likelihood that the WET test data are sampled from the SB hazard (SSD) curve (the s-shaped curve as shown in the example of Figure 1). When the null hypothesis is rejected for platforms, this indicates that it is not likely that the substance and the WET based SSD curves are similar. Note that the reverse is not automatically (for tests that are not rejected).

The Kolmogorov-Smirnov tests are in line with what can be seen in Figure 7 up to Figure 10, shown for option 1 (using the production chemicals estimate at the sampling day), has the least platforms for which the Kolmogorov-Smirnov null hypothesis is rejected (4 rejected cases). This indicates that overall the WET based hazard is most comparable with the SB hazard curve for this option. Options 2 and 4 (using monthly estimates and excluding production chemicals) both have 5 cases where the Kolmogorov-Smirnov null hypothesis was rejected. For option 3 (using yearly production chemical estimates) the number of rejected tests was largest (6 cases). As an example, for Norne the null hypothesis is rejected for option 4 ( $p<0.05$ ), but not for 1,2 and 3 ( $p \geq 0.05$, see Figure 13). This indicates that for platform Norne the options that include the production chemicals (options 1,2 and 3) gives a SB SSD curve that is most comparable with that of the WET tests. Excluding the group of production chemicals (option 4) will result in dissimilar curves for this platform. This can be confirmed visually in Figure 8. Note that the Kolmogorov-Smirnov test (which look at the distance between the entire SSD curve) results do not necessarily match with the comparison of the HC50 levels (which is only a specific point on the SSD curve).

For option 1, 2 and 3, the tests are rejected for platforms Alvheim, Balder, Knarr and Statfjord A. For options 2 and 3 this is also the case for platform Valhall and Skarv. For option 4 (excluding production chemicals) the test is rejected for other platforms: Ekofisk J, Gullfaks A, Gullfaks C, Norne and Snorre A. This suggests that the test is rejected for different reasons when comparing options 1,2 and 3 with option 4, where the first 3 have included production chemicals whereas the latter has not.

For option 3 (using yearly production chemical estimates) there are 6 out of the total 24 platforms (25\%) for which the null hypothesis is rejected. For these platforms it is unlikely that the SB and WET based SSD curves are similar. For options 2 and 4 there are 5 out of 25 platforms (20\%), for option 1 there are 4 out of 25 platforms (16\%). This means that these rejections cannot be attributed to mere coincidence (where it is expected that for only $5 \%(1.25)$ of the 25 platforms the KS null hypothesis would be rejected). It also means that there truly are differences between the SB and WET based SSD curves for specific platforms. In the following sections it was examined whether these differences can be explained (for the HC50). 


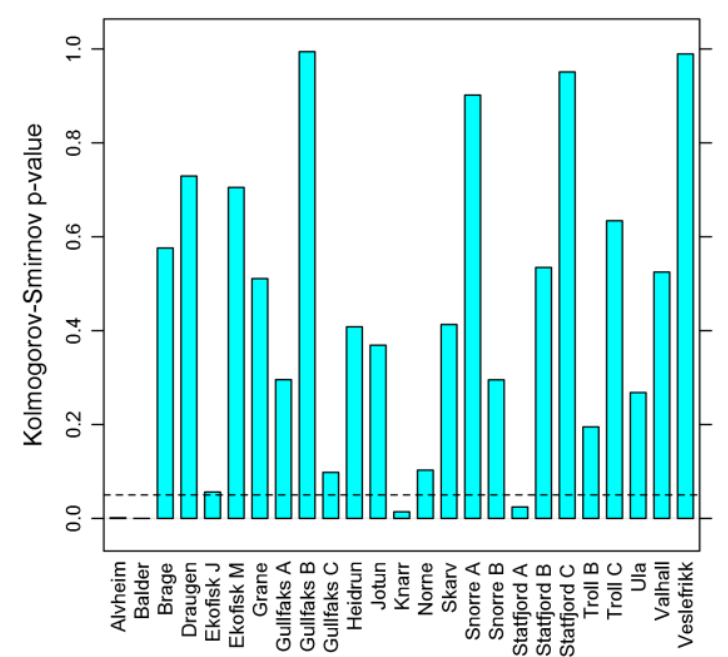

Option 1

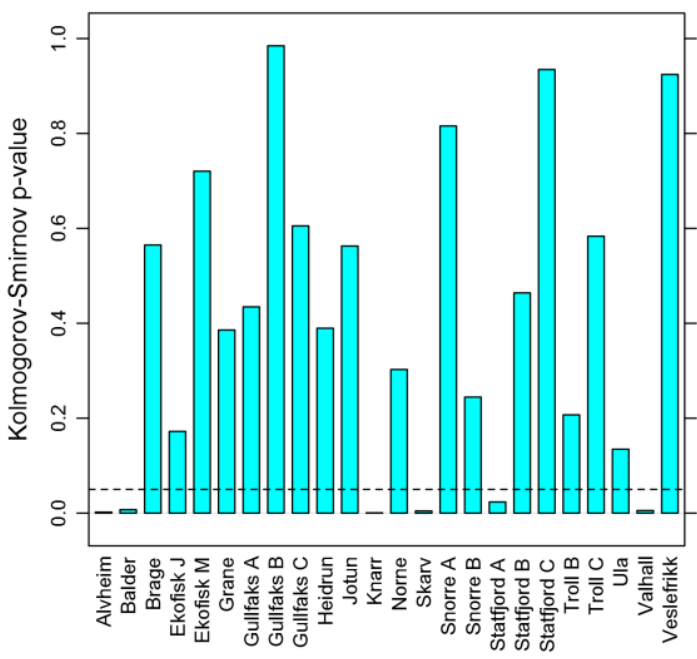

Option 3

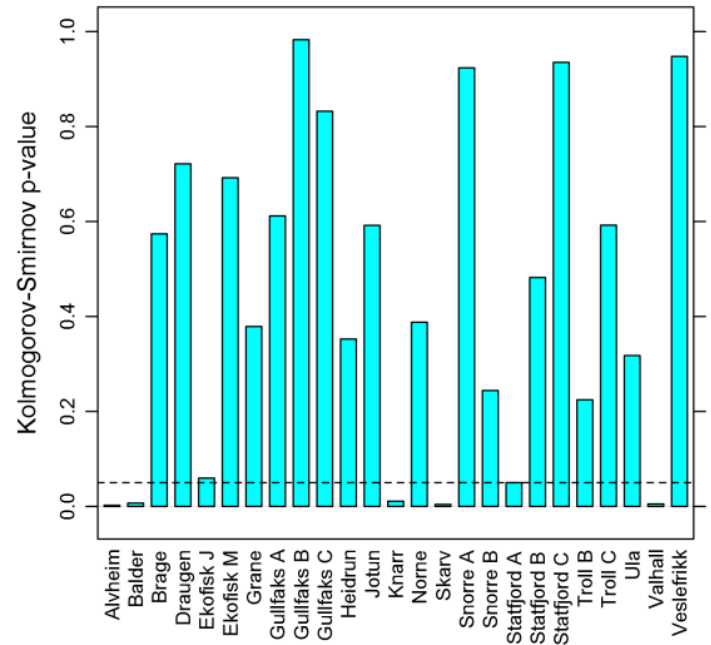

Option 2

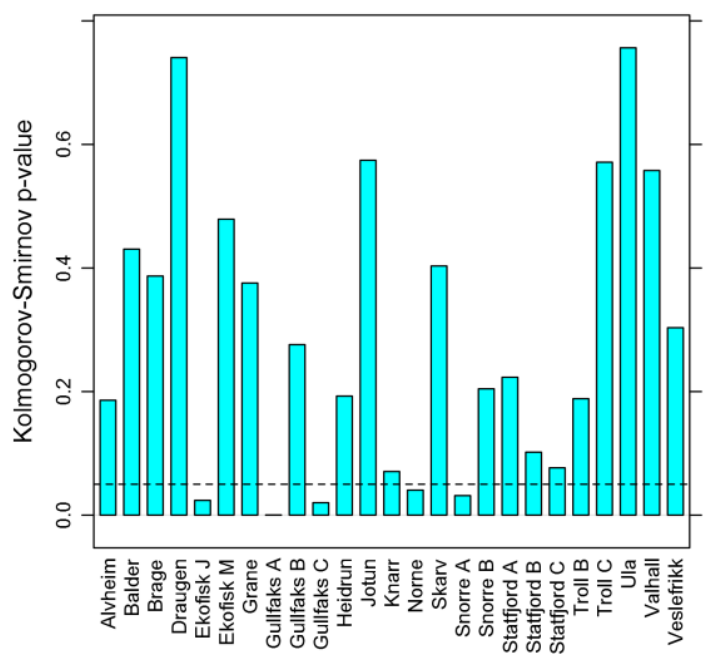

Option 4

Figure 13. Kolmogorov-Smirnov statistics, indicating the likelihood that the WET test data are sampled from the SB hazard (SSD) curve. Dashed line indicates the threshold $(\alpha=0.05)$ for the null hypotheses. Null hypothesis is rejected for platforms below the dashed line (indicating that it is not likely that the substance and the WET based SSD curves are similar). Note that the reverse is not automatically true for platforms above the dashed line (i.e., bars above the dashed lines do not automatically mean that WET based and SB hazard curves are similar).

\subsubsection{Systematic and random differences}

Table 10 presents the ANOVA results for the ordinary linear regression model that was applied to explain the difference between the WET based and SB HC50 estimates for option 1 to 3 which best estimates of discharge concentrations of added chemicals were included. Section 2.5.2.1 in the 'methods' section lists and describes the explanatory variables that were included in the model. Significant effects are shown in boldface in Table 10.

Based on the ANOVA analyses (Table 10), a significant $(p<0.05)$ effect of PC1 (primarily aliphatic hydrocarbons, PAHs and naphthalenes) and PC3 (primarily representing BTEX and C0-C3 phenols) was found (for option 1, 2 and 3). PC1 had a systematic effect on the discrepancy between the SB and WET based HC50 (expressed as the $\log _{10}$ distance to the black solid line $(y=x)$ in Figure 11). This means that the higher the TU of PAHs, naphthalene and aliphatic hydrocarbons are in relation to the other substances, the larger (the more positive) the distance becomes (i.e., the SB HC50 is larger 
than the WET based HC50). In the scatter plot in Figure 11 these samples are more likely to be situated right-hand side of the line $y=x$.

Table 10. ANOVA results for the ordinary linear regression model described in section 2.5.2.1. Important columns are: the 'explanatory variable', indicating for which variable information is presented in a particular row; '\% variation explained' showing how much variation the explanatory variable can explain (for each model this sums up to $100 \%$ ); ' $p$-value' indicates whether an effect is significant (in bold face when $p<$ $0.05)$.

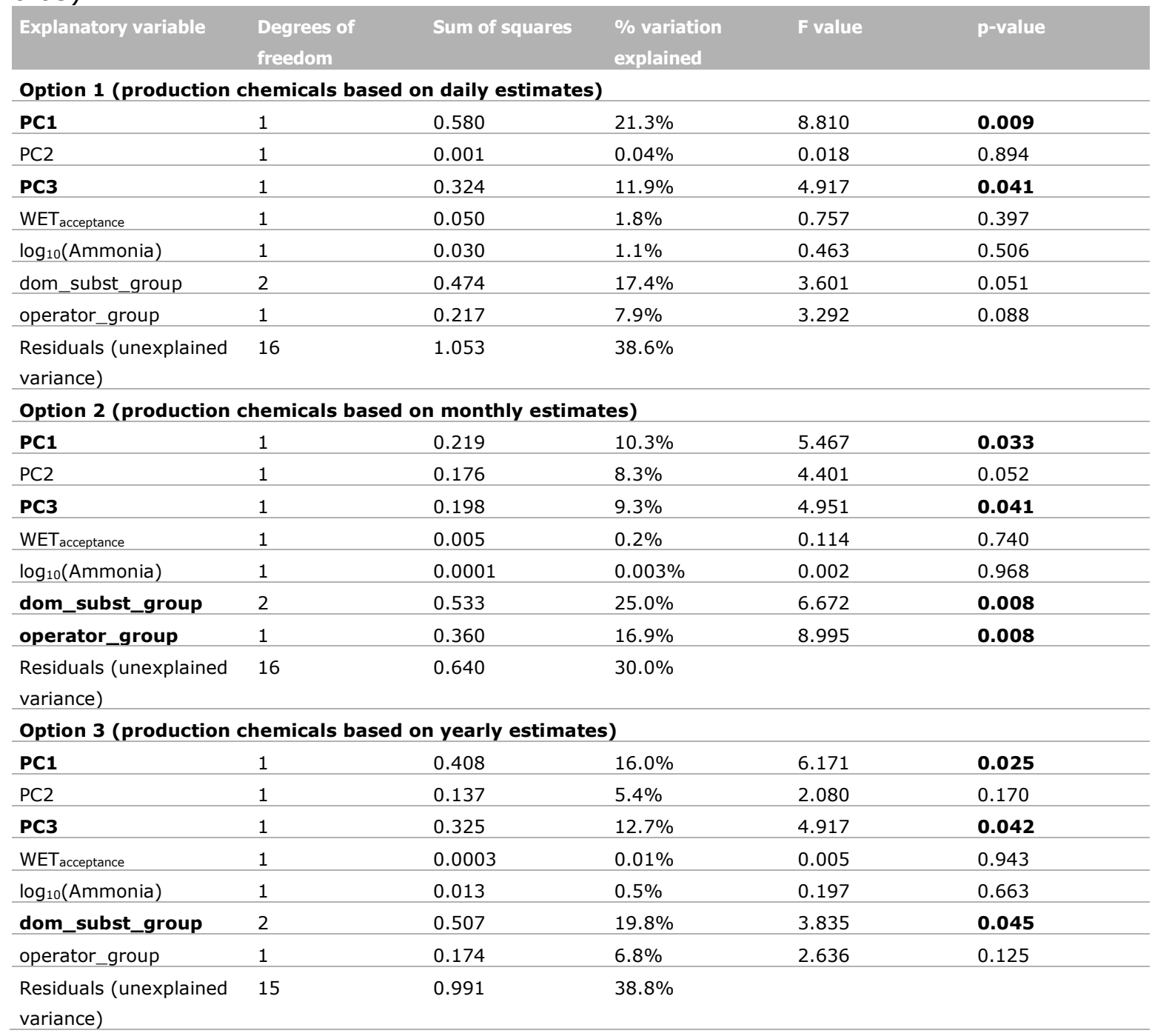

This suggests that either their (the substances that dominate these principal components as listed above) discharge concentration or their toxicity was overestimated. Possibly this is because the aliphatic hydrocarbons were considered as a single group, where toxicity of this group is represented by heptane in the present study. It is known that toxicity may differ for different fractions of such hydrocarbons depending on for instance the molecule chain length (e.g., Redman et al., 2012). Aliphatic hydrocarbons cover linear, branched and cyclic alkanes with variable lengths of carbon chains (typically ranging from $\mathrm{C}_{1}$ (methane) up to very long chains $>\mathrm{C} 78$ ). However, the chemical analytical procedure only covers the fraction between $\mathrm{C7}$ and $\mathrm{C40}$. In the present study only toxic effects of dissolved heptane were included to represent the toxicity of aliphatic hydrocarbons as this substance was used to represent the group before in studies with the EIF (e.g., Møskeland et al., 2014). However, the fraction of larger aliphatic hydrocarbons is not dissolved but present as droplets. On the other hand, baseline toxicity may increase for larger alkanes with increasing octanol water partitioning (logKow) (Escher et al., 2017). Therewith the toxic effects of this group were perhaps not best reflected by this single component.

Smit et al. (2009) reviewed toxicity data for total aliphatic hydrocarbons, but only presents chronic NOEC data (rather than acute EC50 data used in the present study). Assuming an acute to chronic ratio of 10 , the chronic toxicity of total hydrocarbons presented by Smit et al. (2009) for crustaceans 
were in the same range as the acute toxicity to crustaceans presented here for heptane. Given the uncertainty in the toxicity estimates for the other EIF substance groups as well, it is difficult to assert the consequences of a misrepresentation of aliphatic hydrocarbons by heptane.

For PC3 (primarily BTEX and C0-C3 phenols ${ }^{6}$ ) the effect was the other way around: the higher the BTEX and CO-C3 phenol levels become the lower the distance between the WET based and SB HC50 becomes. This suggests that the effects for these groups are well predictable. So, the more these groups contribute to the overall hazard, the better WET based hazard can be predicted from the SB approach (and vice versa). Indeed, toxicity data was well available for these groups (Table 4).

Similarly, an effect was found of the substance group dominating the hazard (Table 10, options 2 and 3). The dominating group was generally either the production chemicals, organic acids or the aliphatic hydrocarbons. This suggests that the hazard was systematically overestimated or underestimated for any of these groups (see also Figure 16). Such errors can originate in both the estimation/measurement of the discharge concentrations or their toxicity. The variation in TU of production chemicals is not very distinctively represented by any of the principal components. Nonetheless, the production chemicals can dominate the hazard. This is partly why the dominating substance group was also included as an explanatory variable in the statistical analysis.

For option 2 the operator group (i.e., Equinor effluents versus effluents of other operators) had an effect on the difference between the WET based and SB HC50. The WET based tests have been performed by the same lab for both operator groups. All chemical analyses were performed using standardised protocols by accredited laboratories. A possible explanation for the difference found between Equinor and the other operators could be that the composition of the effluent is systematically different. However, Figure 12 and Table 9 show that the platforms of the different operators are scattered across the branches of the cluster tree. This indicates that there was not a systematic difference in effluent composition between the operators, so this cannot explain the difference found here.

Another potential explanation of the difference found between the operators is the possible difference in estimating discharge concentration of the production chemicals. If that were the case, it is expected that there is no difference between operators when production chemicals are excluded from the calculations (option 4), or at least a dissimilar decline of the SB hazard for the operators when these chemicals are excluded (unless the hazard posed by production chemicals are higher for the Equinor installations). However, this was not the case (see also Figure 17), meaning that difference between operators cannot be attributed to possible differences in estimating production chemical discharge concentrations in the present study. This does not mean that such differences are not there. Yet another possible explanation are differences between sampling and sample conservation procedures. This is, however, unlikely as these procedures were harmonised. It could also be that the produced water from the Equinor platforms contain larger amounts of 'unknown' substances (i.e., substances that were not included in the programme and are not measured during chemical characterisation). So even though a difference is found between operators in the distance between WET based and SB hazard, none of the possible explanations can be proven with data from the present study. Nonetheless, the first option (differences in production chemical concentrations between operators) is the most plausible.

The other studied variables (PC2, WET acceptance criteria failure, ammonia level), could not significantly explain the differences between SB and WET based HC50 values. The ammonia concentration could not explain the differences, suggesting that this chemical is not as important for the Norwegian platform as for the Australian platforms studied by Parkerton et al. (2018).

Between 30\% and 39\% variance remained unexplained (depending on the option for including production chemicals). This percentage was based on the residuals of the statistical model and would probably be even larger when all non-significant variables (mostly: PC2, ammonia and WET failure) were removed from the model. For option 2 most variance could be explained $(70 \%)$, suggesting that this is the best option for including production chemicals, using monthly estimates. The unexplained variance was caused by factors that are (currently) not known and/or not included in the model. These unknown / unstudied factors could be substances in the PW that contribute to the hazard that were

\footnotetext{
${ }^{6}$ For option 2 (monthly estimates) production chemicals also contribute considerably to PC3, this is not the case for option 1 and 3. Organic acids contribute considerably to PC3 for options 1 and 3 (daily and yearly estimates), this is not so much the case for option 2. See Annex 9
} 
not measured during the chemical characterisation of the effluent. But, also the complex nature of the mixture and to predict interactions of its components (such as e.g. synergism), could have caused the remaining unexplained variance.

Figure 14 shows the perpendicular distance to the line $y=x$ (black diagonal line) in Figure 11. Essentially, Figure 14 rotated the information from Figure 11 with an angle of 225 arc degrees, such that the diagonal line $(y=x)$ in Figure 11 became the horizontal dashed line at 0 in the $y$-axis in Figure 14. But here (Figure 14) the results were sorted by platform and differences between the 4 options for including production chemicals were more clearly depicted as boxplots (the box below shows how boxplots should be interpreted). Option 2 (monthly estimates) produced SB hazards that were on average (median value) closest to the WET based HC50. The variance (size of the bar, excluding error bars (whiskers)) was also largest for this option. The differences between the average distance for options 1, 2 and 3 were marginal. But option 1 (daily estimates) resulted in the least variance in the distance between WET and SB hazard, when you don't include outliers. Note that outliers are depicted separately in Figure 14 (and are not used to determine the median values shown there), but are included in the statistical tests. When the outliers are excluded (as shown in Figure 14), the median value is close to 0 , but it is larger when you do include the outliers (as was done in the statistical analyses). When ignoring the outliers and considering the variance alone, option 1 gives the best fit to the line $y=x$ (Figure 14). Option 2 (monthly estimates) resulted in the next best option, as the variance was less than that of options 3 and 4 and the median distance is $\sim 0$ (meaning that SB HC50 and WET based HC50 were very close on average). It could even be considered to be the best fit Excluding production chemicals from the hazard calculation (option 4) of SB hazard resulted in the largest difference with the WET based hazard.

Interpreting Boxplots

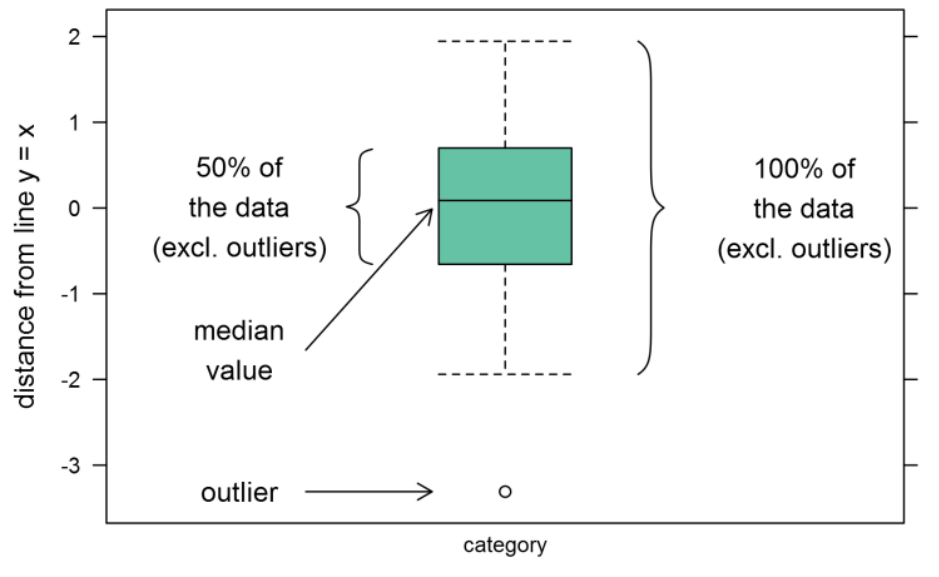

Box plots show the range of values of the data it represents. Outliers are not part of the box and are shown as separate markers outside the box's range. The error bars then show the minimum and maximum value. So $100 \%$ of the data is between the error bars (excluding the outliers of course). The box (from bottom to top) show where $50 \%$ of the data is (again excluding the outliers). The horizontal line in the middle of the box shows where the median value is. In all plots below, the value on the $y$-axis is the perpendicular distance of $\log _{10}$ transformed WET based HC50 and SB HC50 to the line $y=x$ (Figure 11 and Table 7). A distance of zero indicates no difference between WET based and SB hazard. Values above zero indicate that the SB HC50 is larger than the WET based $\mathrm{HC50}$ and values below zero indicate that the WET based HC50 is larger than the SB HC50. 


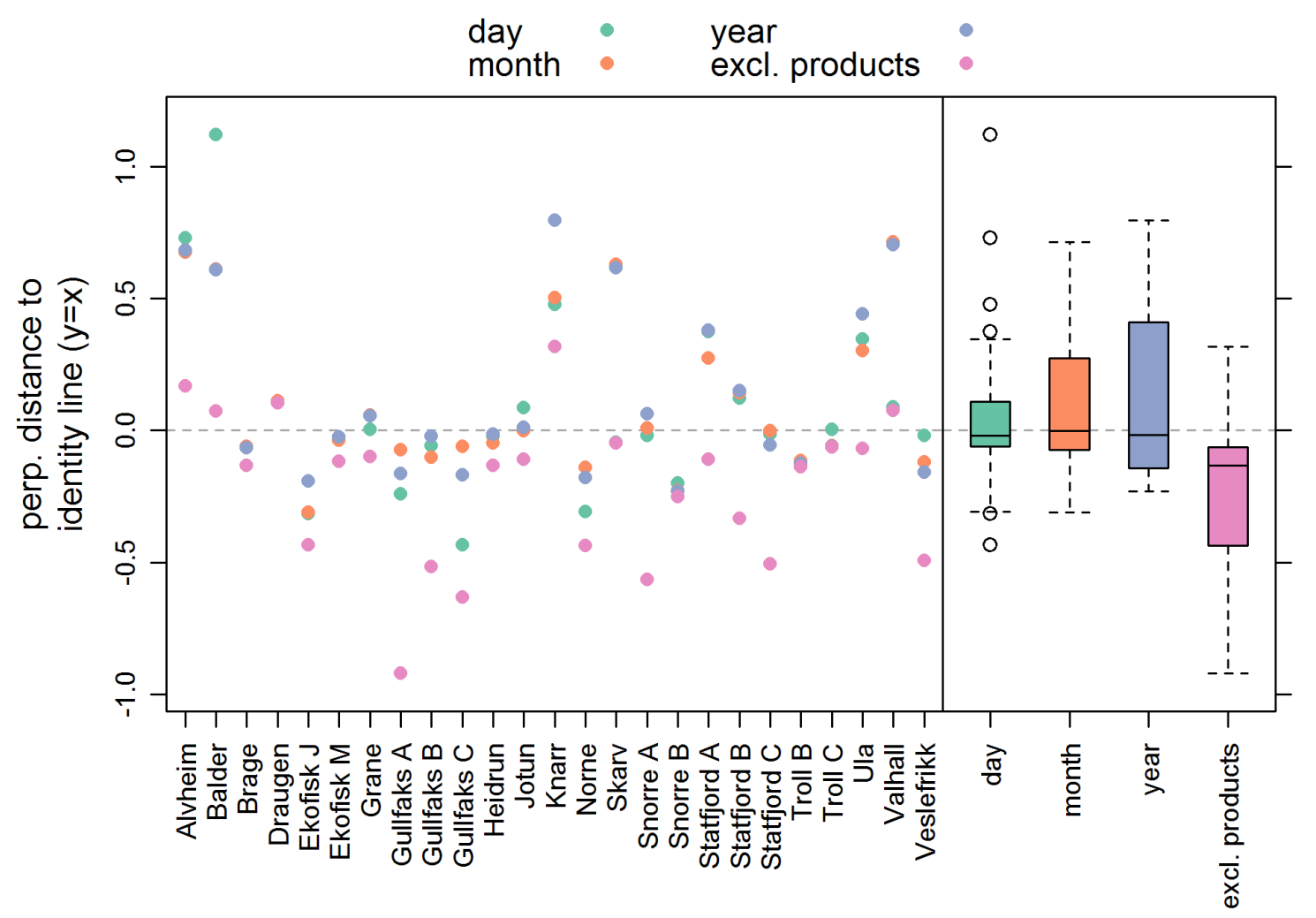

Platform

Figure 14. Perpendicular distance to the line $y=x$ (Figure 11) in $\log _{10}$ units. One $\log _{10}$ unit represents an order of magnitude difference. A distance of zero indicates no difference between WET based and SB hazard. Values above zero indicate that the SB HC50 is larger than the WET based HC50. Error bars indicate minimum and maximum values (excluding outliers). Boxes represent $50 \%$ of the data. Horizontal line in the middle of the box indicates median value. Circles above and below the box plots indicate statistical outliers.

Earlier, the ANOVA analyses did not reveal any systematic effects of failed WET tests on the differences between WET based and SB hazard (Table 10). This does not automatically mean that there was no effect. Figure 15 shows that the variance is larger (i.e., wider bars) for the platforms where one or more of the WET tests failed to meet the acceptance criteria. For example, one test acceptance criteria for the Acartia test was whether the oxygen level was above an acceptable level (> $4 \mathrm{mg} / \mathrm{L}$ ) throughout the test duration. In Figure 15 such failures were only included when the executing laboratory indicated that it could have affected the test result. However, this effect was not significant for any of the options for addressing the production chemicals (tested with Bartlett's test for equal variance). In other words: we cannot say that the width of the boxes in Figure 15 is different for any of the groups in any of the four options. Note that when effects are not detected, it does not mean that they are not there. It could also be that the present experimental setup was not powerful/sensitive enough to detect them. Annex 10 provides a more detailed depiction of the calculated HC50 values and WET test acceptance. 


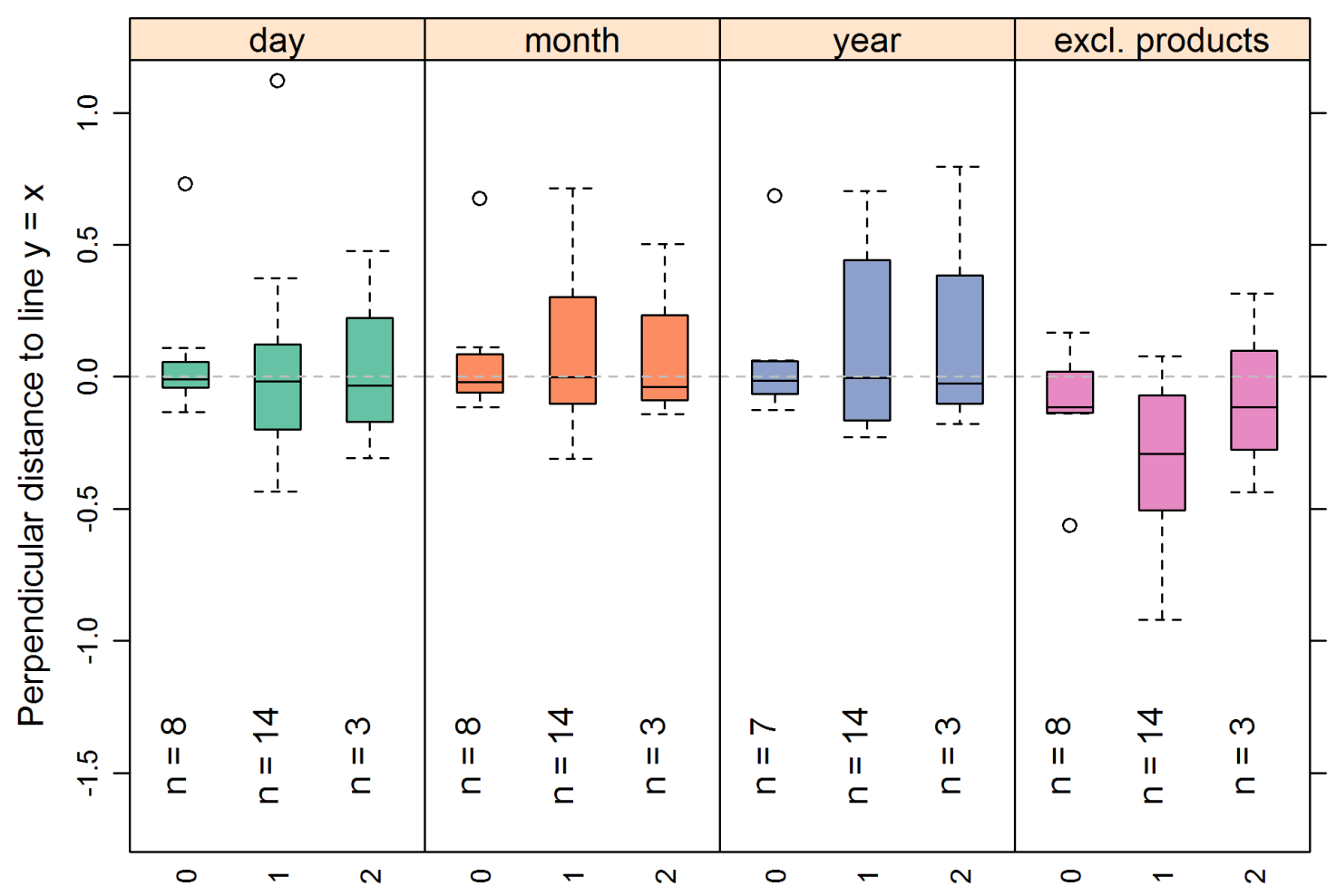

Number of WET tests failing acceptance (potentially affacting test result)

Figure 15. The perpendicular distance to the line $y=x$ (Figure 11), shown for the different options for including production chemicals (option 1 up to 4 shown from the left to the right panel). Values above zero indicate that the SB HC50 is larger than the WET based HC50. The $x$-axis shows the number of WET tests (zero, one and two out of the three tested species) for which the acceptance criteria are not met and to such an extent that the test endpoint (EC/LC50) may have been affected. The $n$-values indicate the number of effluents (platforms) for each number of failed WET tests. Error bars indicate minimum and maximum values (excluding outliers). Boxes represent $50 \%$ of the data. Horizontal line in the middle of the box indicates median value. Circles above and below the box plots indicate statistical outliers.

Similarly, the variance (i.e., the width of the boxes) is larger when SB hazard is dominated by production chemicals if you compare this to situations where other substances dominate the hazard (Figure 16). In this case, the effect on variance is significant only for option $3(p<0.01)$ and borderline for option $1(p=0.05)$ (both Bartlett's test). This suggests that the uncertainty in the estimated hazard is larger when larger amounts of production chemicals are present (and thus dominate the hazard). This makes sense as production chemical concentrations were estimated and not measured. In addition, the number of chemicals (represented as one group) was relatively large and the chemical characteristics diverse, both contributing to the uncertainty of this group. In addition, there was no bacterial toxicity data for this group. The bacterial toxicity was estimated from algae and also adds to the uncertainty of this group.

A side effect of the positive Bartlett's test result (described above) is that the boundary conditions for the ANOVA presented in Table 10 were not met. For the ANOVA it was assumed that variation within each tested group (in this case the substance group that dominates the hazard) was constant. As it is shown here that that was not the case, the ANOVA results should be interpreted with care and considered indicative only.

Also, notable in Figure 16 is that the ratio between the SB and WET based HC50 is lower (in most cases SB HC50 lower than WET based HC50) when the hazard is dominated by organic acids. Note that earlier effects of organic acids were expected to have been overestimated (see section 3.2), which is in contrast with these results. It could be that the effect found here is relative. In other 
words, assuming that effects for the substance groups aliphatic hydrocarbons and production chemicals are expected overestimated, whereas the difference found between WET and SB HC50 for the remaining dominating group (of organic acids) is may caused by other factors (such as unidentified "unknown" substances).

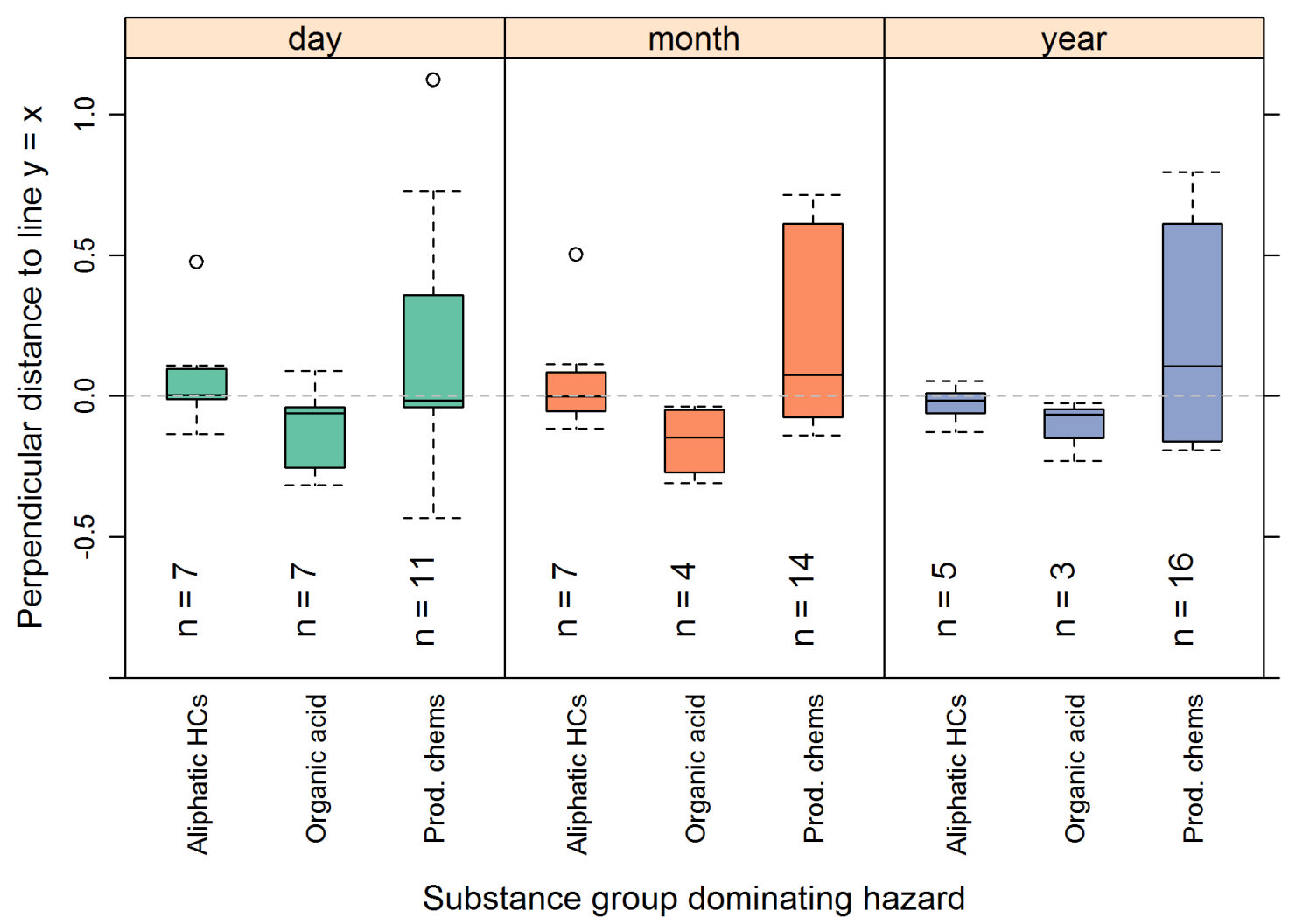

Figure 16. The perpendicular distance to the line $y=x$ (Figure 11), shown for the different options for including production chemicals (option 1 up to 3 shown from the left to the right panel). Values above zero indicate that the SB HC50 is larger than the WET based HC50. The x-axis shows the chemical group that dominates the SB hazard. The $n$-values indicate the number of platforms in each group. Error bars indicate minimum and maximum values (excluding outliers). Boxes represent $50 \%$ of the data. Horizontal line in the middle of the box indicates median value. Circles above and below the box plots indicate statistical outliers.

As previously indicated in Table 10, for option 2 (using monthly estimates for production chemicals) there is a significant difference between operators (based on the ANOVA test), when comparing the distance between SB and WET based hazard. This is visualised in Figure 17. Not only is there a significant difference between the median values of the operators (Table 10), the variance also differs among operators (note that the height of the bars reflect the variance and differ when comparing the operators in Figure 17). Variance in the distance between SB and WET based hazard is smaller for Equinor platforms when compared to the "other operators" (Bartlett test, $p<0.05$ ) except for option 4 (excluding production chemicals, where there is no significant difference in variance between the operators). Apparently, there is variance in the assessment or composition of the production chemicals between the operators, although this cannot explain the difference that is found in the median distance from SB to WET based hazard when compared between operators (Table 10). This observation supports the idea, presented above, that there is a difference between the way production chemical concentrations are estimated by the operators, and that this could affect the hazard assessment. 


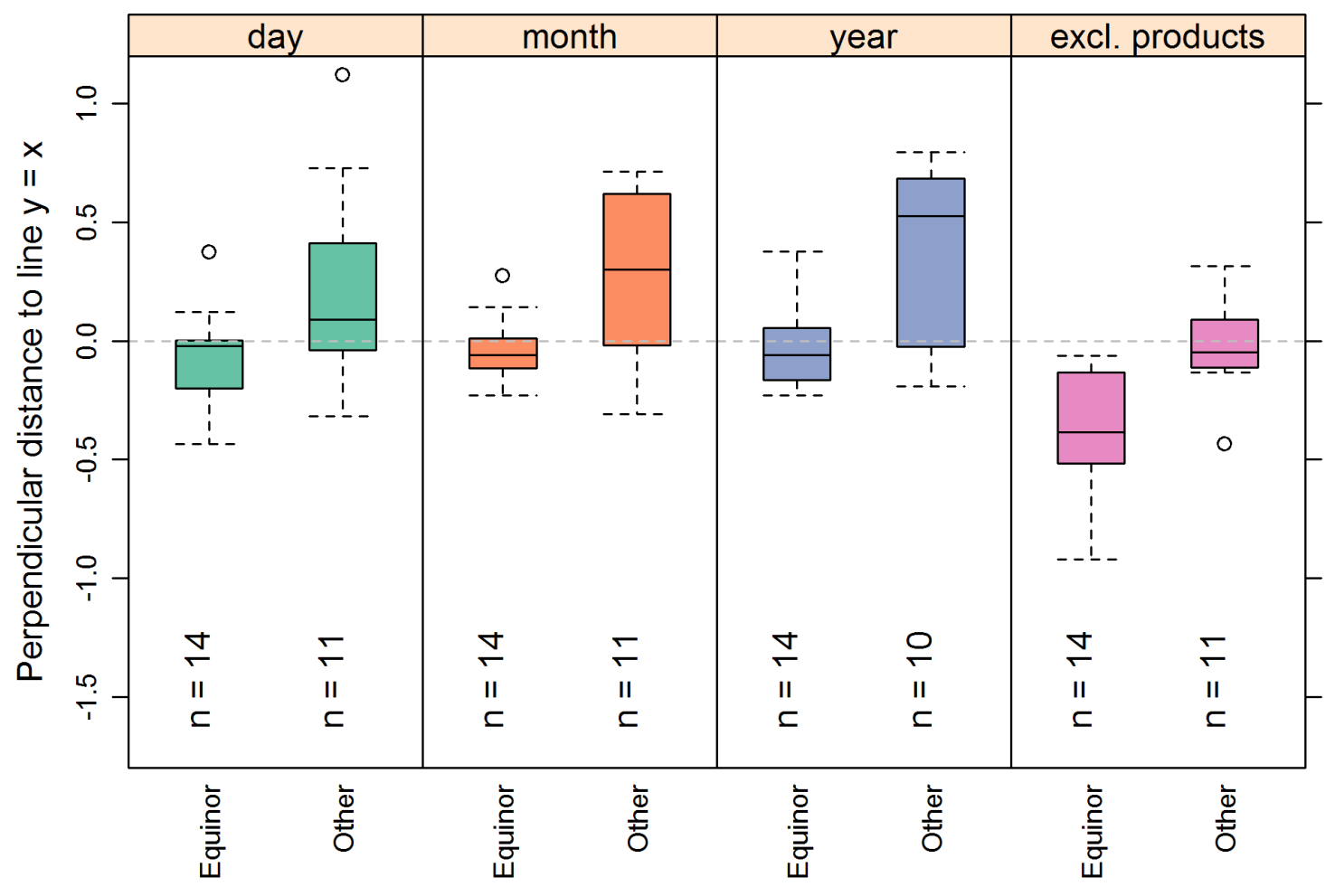

Operator

Figure 17. The perpendicular distance to the line $y=x$ (Figure 11), shown for the different options for including production chemicals (option 1 up to 3 shown from the left to the right panel). Values above zero indicate that the SB HC50 is larger than the WET based HC50. The $x$-axis shows the operator group responsible for the discharge of the effluent. The $n$-values indicate the number of platforms in each group. Error bars indicate minimum and maximum values (excluding outliers). Boxes represent $50 \%$ of the data. Horizontal line in the middle of the box indicates median value. Circles above and below the box plots indicate statistical outliers.

\subsubsection{Sources of uncertainty}

There are several sources of uncertainty that affected the results but could not or were not included in the statistical models. It is important to acknowledge these sources of uncertainty and if possible address them in future studies.

Firstly, there is the uncertainty in TUs resulting from the uncertainty from the chemical characterisation of the effluent (for instance caused by sensitivity of the equipment or the presence of unknown substances not included in the effluent characterisation) and (probably more importantly) the EC50 value used to represent the substances in produced water. As shown for the PAHs (Annex 8 ), the variation of toxicity within the EIF substance group can be considerable. In the present study we relied only on a handful of EC50 values, that is perhaps accurate (i.e., similar test conditions and species), but not very precise due to the limited available data. For some substances bacterial toxicity had to be estimated with an extrapolation model, which also introduces uncertainty. In addition, surrogate test species or deviating test conditions had to be accepted, when collecting from limited available toxicity data, for the use in the hazard calculations. There is also uncertainty in the translation of the TUs into hazard ( $\mathrm{HC50}$ ). For instance, there is uncertainty in the assignment of TMOA to substance groups and the slope parameter that is used to represent the TMOA. The grouping of substances also contributes to the uncertainty as the chemical and toxic characteristics of substances within a group can be variable.

Secondly, there is uncertainty in the estimation of the WET based hazard estimate. This is mostly due to the limited number of species tested and the failure in WET tests that may have resulted in to 
conservative EC/LC50 values. Although the uncertainty caused by the limited number of tests is depicted in Figure 11, it is not included in the statistical analyses. 


\section{$4 \quad$ Conclusions and recommendations}

The acute hazard (expressed as HC50) of the PW effluents matched well in the present study when the whole effluent toxicity (WET) based approach and the substance based (SB) approach were compared. They were less than an order of magnitude (a factor of 10) apart for most effluents for all options (92 to 96\%). The median ratio between the two hazard approaches was close to 1 ( 0.95 for calculations that included production chemicals; option 1, 2 and 3), indicating good similarity between the two approaches. On average, the WET based approach resulted in slightly higher hazard estimates than the SB approach (when expressed as the HC50). When production chemicals were excluded from the SB calculation, the median ratio was 0.65 , showing that the SB approach underestimated the hazard of the effluent when production chemicals were excluded.

In summary, the WET and SB hazard (expressed by HC50) based on the discharge profile for added chemical option 1 (day of sampling for WET) corresponded well for 16 out of the total 25 platforms $(64 \%)$, as the difference between the SB and WET based approach is less than a factor of 2 . This is the case for platforms Brage, Draugen, Ekofisk M, Grane, Gullfaks B, Heidrun, Jotun, Skarv, Snorre A, Snorre B, Statfjord B, Statfjord C, Troll B, Troll C, Valhall and Veslefrikk. This percentage is the same for the options 2 and 3, although they cover different platforms. For option 4 (excluding production chemicals) only 14 out of the 25 (56\%) platforms show a difference of less than a factor of 2 between the SB and WET based approach.

For 4 out of the 25 platforms (16\%) the WET based hazard was more than a factor 2 higher (more conservative) than the SB hazard based on option 1: Ekofisk J, Gullfaks A, Gullfaks C and Norne. For option 2 this is only the case for 2 platforms ( $8 \%$ ): Ekofisk J and Snorre B, andfor option 3 only Snorre B (4\%). For option 4 the WET based HC50 is more than a factor 2 higher than the SB HC50 for 10 out of the 25 platforms (40\%). This suggests that for those options that include added chemicals, either not all relevant substances were included in the SB approach, toxicity of one or more substance groups were underestimated, not all toxic interactions were correctly included in the SB approach, or a combination of these aspects. The average difference was however small.

For 5 out of 25 platforms (20\%) the SB hazard was more than a factor 2 higher than the WET based hazard for option 1: Alvheim, Balder, Knarr, Statfjord A and Ula. This is also the case for options 2 and 3. However for options 2 and 3 there are 2 additional platforms (Valhall and Skarv), making a total of 7 out of $25(28 \%)$ or out of 24 (29\%, in case of option 3$)$, where the SB hazard was more conservative (factor $\geq 2$ ) than the WET hazard. For option 4 this was only the case for platform Knarr (4\%). One plausible explanation to this may be that the discharge concentrations of production chemicals were estimated rather than measured in the effluent, and may have been overestimated for these platforms.

Despite the similarities between the WET and SB hazard, there was also variation between the two approaches, which was tested statically against several potentially explanatory variables. Differences between the WET and SB approach were partly explained by differences in the effluent composition, particularly for the substance groups that dominate the acute hazard (aliphatic hydrocarbons, production chemicals or organic acids). For aliphatic hydrocarbons, either the discharge concentration or their toxicity (or both) were overestimated in the SB approach. This was also the case for production chemicals, where also a lot of variation was found in the SB hazard estimate. This was probably caused by the fact that discharge concentrations were estimated rather than measured in the effluent. When organic acids dominated the hazard, the SB HC50 was lower when compared to the WET based approach. Whether this was caused by the organic acids themselves or the fact that the hazard was not dominated by aliphatic hydrocarbons nor by production chemicals, was not clear.

It is recommended to study these three groups of PW substances (aliphatic hydrocarbons, production chemicals and organic acids) more closely, if possible in addition to groups for which toxicity may have been underestimated (such as PAHs) or where uncertainty in toxicity is large (e.g., where toxicity was extrapolated rather than measured). In particular, issues that affect the estimation / measurement of 
discharge concentrations or the evaluation of the toxicity of these groups (in relation to the WET tests that are performed with the effluent). In the methods and results sections several issues were addressed, including the facts that: aliphatic hydrocarbon toxicity was represented by heptane, whereas the complete group was composed of heavier components; (organic) acids affect the pH and bioavailability of other components (samples in the WET tests were neutralised, in the SB approach it was not always clear how samples were tested); production chemical concentrations were estimated by the operators, not measured. And there seem to be differences in the way of calculating discharges of added chemicals between operators that are recommended to be considered.

The statistical analysis shows that the largest part of the variation in the difference between SB and WET based hazard remained unexplained. In other words: it is not known what caused the largest part of the differences observed between WET and SB hazard estimates. In order to better understand how large the effects need to be in order to be detected, it is recommended for a future study to perform a power analysis for the statistics and data presented in the present study. This should provide more information on the sensitivity of the present experimental setup. It will also provide insight into how the experimental setup can be improved and at what cost. Before doing this, it is beneficial to further refine the analysis performed here. In the present study grouping of substances had to be applied, where this grouping used for the EIF was mostly adopted. Partly based on data availability it should be evaluated whether the grouping should be revised, especially if chemical and toxicological properties are highly variable within a group. In the present study toxicity data was collected in a structured fashion, using the ECETOC EAT and EPA ECOTOX database only. In a follow-up it should be considered if there are better suited toxicity data that match with the toxicity tests used in the WET based approach. An additional improvement would be to further harmonize the derivation of production chemical concentrations.

An effect of the operator was explaining some of the difference between the SB and WET based hazard in the statistical analysis. In the present study no satisfying explanation could be found for the observed difference between operators. It is therefore recommended to have a closer look at differences between the operators and determine whether these differences can explain the effects observed here. Possible differences between operators are: differences in estimation of discharge concentration of added chemicals, chemical composition of the effluents (although this cannot be validated in the present study); differences between sampling and sample handling procedures (including conservation and transport); differences in chemical analyses; differences in WET tests (the latter is not likely as all WET tests were performed with the same protocols by the same laboratory). Where the first suggestion (differences in the way added chemical concentrations are estimated) is the most plausible.

Current OSPAR guidelines allow member states to apply either the WET or the SB risk approach, or both. This study focused on comparing hazards rather than risks of the two approaches to avoid dissimilarities between the methods. The OSPAR SB approach uses PNECs mainly based on chronic toxicity data and are therefore based on lower assessment factors compared to the OSPAR WET based approach, where only acute toxicity data is generated and a maximum assessment factor (1000) is used. Furthermore, no attenuation factors (biodegradation, evaporation etc.) are accounted for in dilution/dispersion modelling in the WET approach, while this is accounted for in the formal SB approach.

This study shows that even when "similar" conditions (e.g., exposure duration and test species as used in WET tests) are selected and used for both approaches, results (although in the same range) differ. These differences are expected to be even larger when the formal RBA guidelines would be followed, as the SB approach would require the attenuation and assessment factors as described above. This suggests that the information obtained from the WET tests and a SB approach are complementary (address different aspects of hazard) and should not be used interchangeably.

How well EIF substances cover the risk of a produced water discharge could not be concluded directly from the present study, as the present SB approach evaluated acute effects, whereas the EIF addresses chronic effects. Discrepancy between WET based and SB hazard can be the result of uncertainties in the composition and toxicity of the produced water. These specific issues (e.g., 
uncertainty in added produced chemicals concentrations; 'unknown' substances that are not measured during chemical characterisation) also apply to the EIF.

The overall goal of OSPAR's risk based approach is the reduction of risk and continuous effort for improvement. In the present study the acute hazard was compared between the WET based and SB approach on an absolute scale. Although differences were generally within an order of magnitude, there was still some variation. However, in future, when both the WET based and SB approach are used to monitor the hazard of a platform's discharge over time, it may be more valuable to evaluate whether both approaches indicate similar reduction of hazard over time. This opposed to comparing the two approaches on an absolute scale at one point in time (as was done in the present study). For the next risk based assessment cycle, it is recommended to evaluate the hazard reduction for effluent discharges and compare these reductions using the WET based versus the SP approach. This will only work when identical procedures are followed in both cycles (so either follow the same procedures described in the present study to the next cycle, or apply updated procedures to data from the present study). 


\section{Quality Assurance}

IMARES utilises an ISO 9001:2008 certified quality management system (certificate number: 1873782015-AQ-NLD-RvA). This certificate is valid until 15 December 2018. The organisation has been certified since 27 February 2001. The certification was issued by DNV Certification B.V. 


\section{References}

Aas, N., Knudsen, B., Sæten, J.O. and Nordstad, E. (2002). Mass balance of production chemicals. SPE 74083, 20-22 March, 2002, Kuala Lumpur, Malaysia.

Aldenberg, T., Jaworska, J.S., and Traas, T.P. (2002). Normal Species Sensitivity Distributions and Probabilistic Ecological Risk Assessment, in Species Sensitivity Distributions in Ecotoxicology, L. Posthuma, G.W. Suter II, and T.P. Traas, Editors. 2002, CRC Press LLC: Boca Raton, Florida, USA.

Clarkson, D. B., Fan, Y. and Joe, H. (1993). A Remark on Algorithm 643: FEXACT: An Algorithm for Performing Fisher's Exact Test in $r$ x c Contingency Tables. ACM Transactions on Mathematical Software, 19, 484-488.

Crommentuijn, T., Polder, M.D. and Van de Plassche, E.J. (1997). Maximum Permissible Concentrations and Negligible Concentrations for metals, taking background concentrations into account. 1997, Report: 601501001, RIVM, Bilthoven, The Netherlands.

De Vries, P. and Karman, C.C. (2011). Whole Effluent Toxicity and Substance-based Hazard Assessment of Produced Water. Report C162/11. IMARES, Den Helder, The Netherlands

De Zwart, D. and Posthuma, L. (2005). Complex mixture toxicity for single and multiple species: Proposed methodologies. Environmental Toxicology and Chemistry 24(10): p. 2665-2676.

Escher, B.I., Baumer, A., Bittermann, K., Henneberger, L. Konig, M. Kuhnert, C. and Kluver, N. (2017). General baseline toxicity QSAR for nonpolar, polar and ionisable chemicals and their mixtures in the bioluminescence inhibition assay with Aliivibrio fischeri. : Environmental Science: Processes \& Impacts 19, p. 414-428NOG (2012): Norwegian Oil and Gas recommended guidelines for sampling and analysis of produced water, No: 085. Established: 11.06.2003, Revision 11.12.2012.

https://www.norskoljeoggass.no/Global/Retningslinjer/Miljø/085\%20Norwegian\%20oil\%20and\%2 0gas $\% 20$ recommended\%20guidelines\%20for\%20samling\%20and\%20analysis\%20of\%20produce d\%20water,\%20rev\%201,\%2011.12.2012.pdf

Harbers J.V., Huijbregts M.A., Posthuma L. and Van de Meent D. (2006) Estimating the impact of high-production-volume chemicals on remote ecosystems by toxic pressure calculation. Environmental Science and Technology 40(5): p. 1573-80.

Loibner, A.P., Szolar, O.H.J., Braun, R. and Hirmann, D. (2004) Toxicity Testing of 16 Priority Polycyclic Aromatic Hydrocarbons Using LUMISTOX. Environmental Toxicology and Chemistry 23(3), pp. 557-564

Møskeland, T., Ulfsnes, A., Oksrød, B., Jonsson, H., and Ditlevsen, M.K. (2014) Johan Sverdrup Dispersion modeling, resource mapping and environmental assessment. Report 2014-1165, Rev. 0. SINTEF, Norway

Murtagh, F. and Legendre, P. (2014). Ward's hierarchical agglomerative clustering method: which algorithms implement Ward's criterion? Journal of Classification 31(3): p. 274-295.

OSPAR (2008). OIC, Meeting of the Offshore Industry Committee (OIC): Summary Record. 2008, Report: OIC 08/13/1-E, Offshore Industry Committee of OSPAR Convention for the protection of the Marine Environment of the North-East Atlantic, Bonn.

OSPAR (2012a). OSPAR Recommendation 2012/5 for a risk-based approach to the Management of Produced Water Discharges from Offshore Installations:

http://www.ospar.org/documents/dbase/decrecs/recommendations/12-

05e_RBA\%20Recommendation.doc

OSPAR (2012b). OSPAR Guidelines in support of Recommendation 2012/5 for a Risk-based Approach to the Management of Produced Water Discharges from Offshore Installations, (OSPAR

Agreement: 2012-7): http://www.ospar.org/documents/dbase/decrecs/agreements/1207e_rba\%20guidelines.doc

OSPAR (2013). Risk-Based Approach to the Management of Produced Water Discharges from Offshore Installations:

http://www.ospar.org/html_documents/ospar/html/data/assessment_fact_sheets/ospar_factsheet _rba_2013.pdf 
OSPAR 12/22/1, Annex 19. OSPAR Guidelines in support of Recommendation 2012/5 for a Risk-based Approach to the Management of Produced Water Discharges from Offshore Installations (OSPAR Agreement: 2012-7, updated by OIC 2014).

OSPAR (2014): Background document for establishment of a list of Predicted No Effect Concentrations (PNECs) for naturally occurring substances in produced water. PNECs list for use in the Risk Based Approach to the management of produced water discharged from offshore installations (OSPAR Recommendation 2012/5).

Parkerton, T.F., Bok, M., Ireland, A.W. and Prosser, C.M. (2018). An evaluation of cumulative risks from offshore produced water discharges in the Bass Strait. Marine Pollution Bulletin 126: p. 610621

Redman, A.D., Parkerton, T.F., McGrath, J.A. and Di Toro, D.M. (2012). PETROTOX: an aquatic toxicity model for petroleum substances. Environmental Toxicology and Chemistry 31(11): p. 2498-2506

RIVM, e-Tox database. 2005: Bilthoven, The Netherlands.

Smit, M.G.D., Bechmann, R, Hendriks, A.J. Kadsheim, A. Larsen, B.K., Baussant, T., Bamber, S. and Sanni, S. (2009). Relating biomarkers to whole-organism effects using species sensitivity distributions: a pilot study for marine species exposed to oil. Environmental Toxicology and Chemistry 28(5): p. 1104-1109

Smit, M.G.D., Jak, R.G. Rye, H. Frost, T.K. Singsaas, I. and Karman C.C. (2008). Assessment of environmental risks from toxic and nontoxic stressors; A proposed concept for a risk-based management tool for offshore drilling discharges. Integrated Environmental Assessment and Management 4(2): p. 177-183.

Smit, M.G.D., T.K. Frost and S. Johnsen, 2011. Achievements of Risk-Based Produced Water Management on the Norwegian Continental Shelf (2002-2008). Integrated Environmental Assessment and Management 7(4): p. 668-677

Verbruggen, E.M.J. (2012) Environmental risk limits for polycyclic aromatic hydrocarbons (PAHs) for direct aquatic, benthic, and terrestrial toxicity. Report 607711007/2012, RIVM, The Netherlands

Zhang, X.J., Qin, H.W., Su, L.M., Qin, W.C., Zou, M.Y., Sheng, L.X., Zhao, Y.H. and Abraham, M.H. (2010). Interspecies correlations of toxicity to eight aquatic organisms: Theoretical considerations. Science of the Total Environment 408(20): p. 4549-4555 


\section{Justification}

Report C080/18

Project Number: 4315100020

The scientific quality of this report has been peer reviewed by a colleague scientist and a member of the Management Team of Wageningen Marine Research.

Approved: $\quad$ Jacqueline E. Tamis

Research Scientist

Signature:

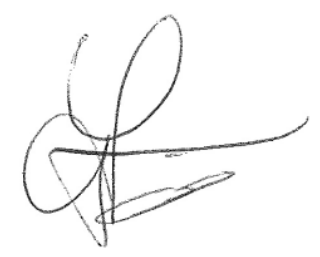

Date:

8 November 2018

Approved:

Dr. T.P. Bult

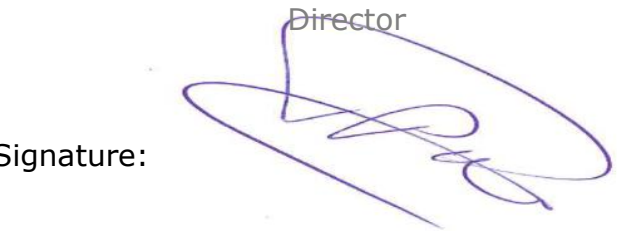

Date:

8 November 2018 


\section{Annex 1 'Natural' substances used to collect toxicity data}

Table 1.1

EIF groups with corresponding substances and (Chemical Abstract Service) CAS numbers and their Toxic Mode of Action (TMOA)

\begin{tabular}{|c|c|c|}
\hline EIF group & EIF substance & CAS number TMOA \\
\hline BTEX & Benzene & $71-43-2$ NN \\
\hline BTEX & Toluene & $108-88-3 \mathrm{NN}$ \\
\hline BTEX & Ethyl-benzene & $100-41-4 \mathrm{NN}$ \\
\hline BTEX & Xylene & $1330-20-7 \quad N N$ \\
\hline BTEX & o-Xylene & $95-47-6 \mathrm{NN}$ \\
\hline BTEX & p-Xylene & $106-42-3 \mathrm{NN}$ \\
\hline BTEX & m-Xylene & $108-38-3 \mathrm{NN}$ \\
\hline Aliphatic hydrocarbons & Heptane & $142-82-5 \quad N N$ \\
\hline Naphthalene & Naphthalene & $91-20-3 \mathrm{NN}$ \\
\hline Naphthalene & 1-MethyINaphthalene & $90-12-0 \quad N N$ \\
\hline Naphthalene & 2-MethyINaphthalene & $91-57-6 \mathrm{NN}$ \\
\hline Naphthalene & 2,6-DimethyINaphthalene & $581-42-0 \quad N N$ \\
\hline Naphthalene & 2-IsopropylNaphthalene & $2027-17-0 \quad N N$ \\
\hline PAH 2-3 ring & Acenaphthylene & $208-96-8 \mathrm{NN}$ \\
\hline PAH 2-3 ring & Acenaphthene & $83-32-9 \mathrm{NN}$ \\
\hline PAH 2-3 ring & Fluorene & $86-73-7 \quad N N$ \\
\hline PAH 2-3 ring & Phenanthrene & $85-01-8 \mathrm{NN}$ \\
\hline PAH 2-3 ring & 9-Methylphenantrene & $883-20-5 \mathrm{NN}$ \\
\hline PAH 2-3 ring & 9-Ethylphenantrene & $3674-75-7 \quad N N$ \\
\hline PAH 2-3 ring & 1,2,6-Trimethylphenantrene & $30436-55-6 \mathrm{NN}$ \\
\hline $\mathrm{PAH} 2-3$ ring & Anthracene & $120-12-7 \mathrm{NN}$ \\
\hline PAH 2-3 ring & Dibenzothiophene & $132-65-0 \quad N N$ \\
\hline PAH 2-3 ring & 4-Methyldibenzothiophene & $7372-88-5 \quad N N$ \\
\hline PAH 2-3 ring & 4-Ethyldibenzothiophene & $89816-99-9 \quad N N$ \\
\hline PAH 4+ ring & Fluoranthene & $206-44-0 \quad N N$ \\
\hline PAH 4+ ring & Pyrene & $129-00-0 \mathrm{NN}$ \\
\hline $\mathrm{PAH} 4+$ ring & Chrysene & $218-01-9 \mathrm{NN}$ \\
\hline PAH 4+ ring & bens(a)antrasen & $56-55-3 \mathrm{NN}$ \\
\hline PAH 4+ ring & Benzo(b)fluoranthene & $205-99-2 \mathrm{NN}$ \\
\hline $\mathrm{PAH} 4+$ ring & Benzo(k)fluoranthene & $207-08-9 \quad N N$ \\
\hline PAH 4+ ring & Benzo(a)pyrene & $50-32-8 \mathrm{NN}$ \\
\hline PAH 4+ ring & Indeno(123,cd)pyrene & $193-39-5 \mathrm{NN}$ \\
\hline $\mathrm{PAH} 4+$ ring & Dibenzo(ah)anthracene & $53-70-3 \mathrm{NN}$ \\
\hline $\mathrm{PAH} 4+$ ring & Benzo(ghi)perylene & $191-24-2 \mathrm{NN}$ \\
\hline Phenol CO-C3 & Phenol & $108-95-2 \mathrm{PN}$ \\
\hline Phenol CO-C3 & o-cresol & $95-48-7 \quad \mathrm{PN}$ \\
\hline Phenol CO-C3 & m-cresol & $108-39-4 \mathrm{PN}$ \\
\hline Phenol CO-C3 & p-cresol & $106-44-5 \mathrm{PN}$ \\
\hline Phenol CO-C3 & 2,5-Xylenol & $95-87-4 \quad P N$ \\
\hline
\end{tabular}




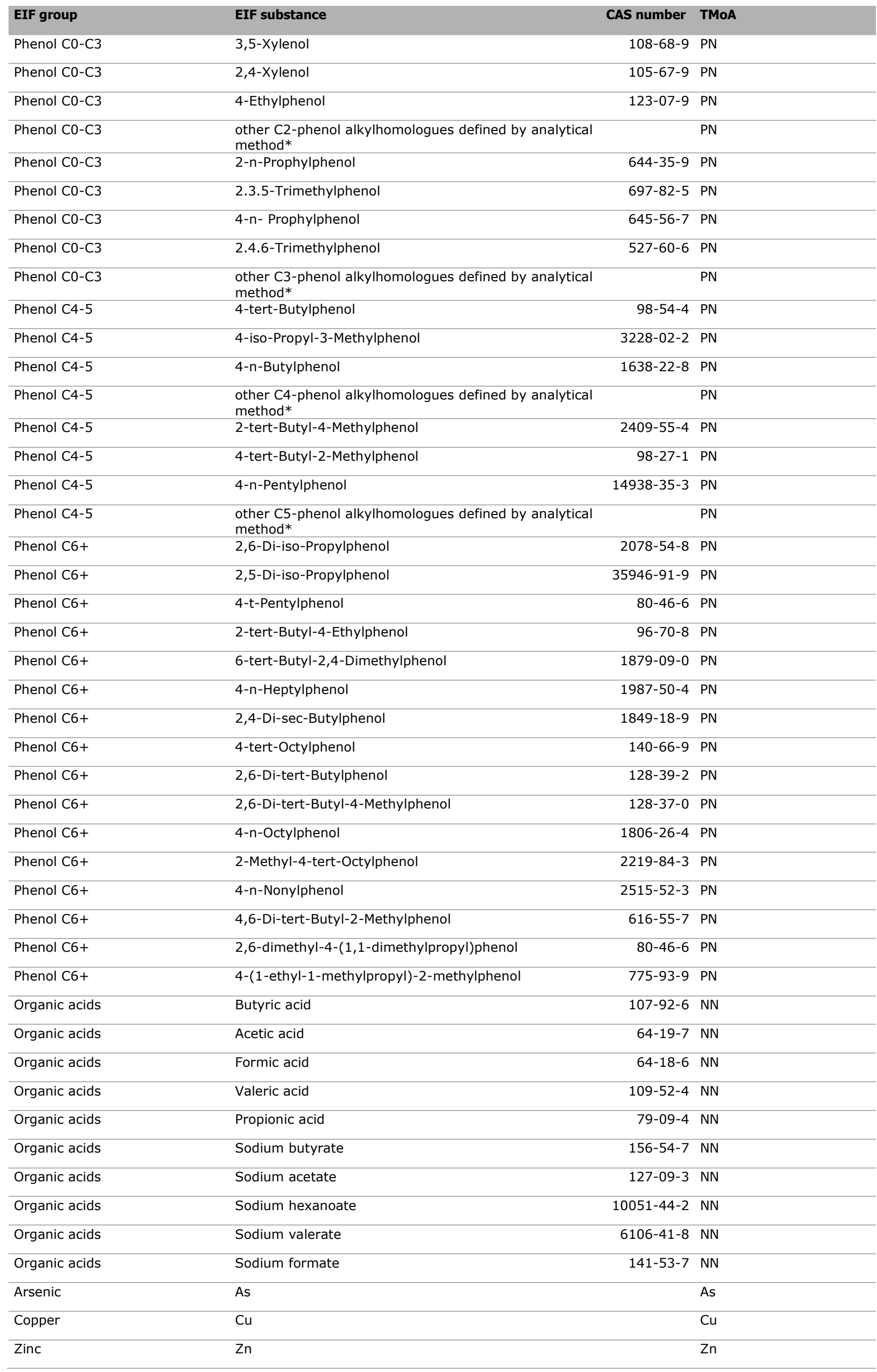




\begin{tabular}{|c|c|c|c|}
\hline EIF group & EIF substance & CAS number & TMOA \\
\hline Nickel & $\mathrm{Ni}$ & & $\mathrm{Ni}$ \\
\hline Lead & $\mathrm{Pb}$ & & $\mathrm{Pb}$ \\
\hline Cadmium & $\mathrm{Cd}$ & & $\mathrm{Cd}$ \\
\hline Chromium & $\mathrm{Cr}$ & & $\mathrm{Cr}$ \\
\hline Mercury & $\mathrm{Hg}$ & & $\mathrm{Hg}$ \\
\hline Production chemicals & Monoethylene Glycol & $107-21-1$ & NN \\
\hline Production chemicals & Methanol & $67-56-1$ & NN \\
\hline
\end{tabular}


$\begin{array}{ll}\text { Annex } 2 & \begin{array}{l}\text { Selected toxicity data } \\ \text { (crustacea and algae) }\end{array}\end{array}$ 


\section{Table 2.1}

Effect concentrations as collected for the 'natural' substances and crustacea and algae as used in hazard calculations. Data from the US EPA ECOTOX database, unless mentioned otherwise. Test medium indicates whether the test was performed in freshwater (FW) or saltwater (SW).

\begin{tabular}{|c|c|c|c|c|c|c|c|c|c|}
\hline EIF group & EIF substance & Endp. & Eff. conc. & Obs. dur. & $\begin{array}{l}\text { Test } \\
\text { medium }\end{array}$ & Latin name & Phylum / division & Family & $\begin{array}{l}\text { Species } \\
\text { group }\end{array}$ \\
\hline BTEX & Benzene & LC50 & $710000 \mathrm{ug} / \mathrm{L}$ & $96 \mathrm{~h}$ & FW & D. forbesi & Arthropoda & Diaptomidae & crust \\
\hline BTEX & Benzene & LC50 & $111.5 \mathrm{ppm}$ & $24 \mathrm{~h}$ & sw & N. spinipes & Arthropoda & Ameiridae & crust \\
\hline BTEX & Benzene & LC50 & $82 \mathrm{ppm}$ & $24 \mathrm{~h}$ & sw & N. spinipes & Arthropoda & Ameiridae & crust \\
\hline BTEX & Ethyl-benzene & LC50 & $40 \mathrm{ppm}$ & $24 \mathrm{~h}$ & sw & N. spinipes & Arthropoda & Ameiridae & crust \\
\hline BTEX & Ethyl-benzene & LC50 & $16 \mathrm{ppm}$ & $24 \mathrm{~h}$ & sw & N. spinipes & Arthropoda & Ameiridae & crust \\
\hline BTEX & Toluene & LC50 & $215000 \mathrm{ug} / \mathrm{L}$ & $96 \mathrm{~h}$ & FW & C. viridis & Arthropoda & Cyclopidae & crust \\
\hline BTEX & Toluene & LC50 & $24.2 \mathrm{ppm}$ & $24 \mathrm{~h}$ & sw & N. spinipes & Arthropoda & Ameiridae & crust \\
\hline BTEX & Toluene & LC50 & $74.2 \mathrm{ppm}$ & $24 \mathrm{~h}$ & sw & N. spinipes & Arthropoda & Ameiridae & crust \\
\hline BTEX & Xylene & LC50 & $99500 \mathrm{ug} / \mathrm{L}$ & $96 \mathrm{~h}$ & FW & D. forbesi & Arthropoda & Diaptomidae & crust \\
\hline $\begin{array}{l}\text { Aliphatic } \\
\text { hydrocarbons }\end{array}$ & Heptane & EC50 & $82500 \mathrm{ug} / \mathrm{L}$ & $96 \mathrm{~h}$ & FW & D. magna & Arthropoda & Daphniidae & crust \\
\hline $\begin{array}{l}\text { Aliphatic } \\
\text { hydrocarbons }\end{array}$ & Heptane & LC50 & $>50 \mathrm{mg} / \mathrm{L}$ & $24 \mathrm{~h}$ & FW & D. magna & Arthropoda & Daphniidae & crust \\
\hline Naphthalene & 2,6-Dimethylnaphthalene & LC50 & $852 \mathrm{ug} / \mathrm{L}$ & $24 \mathrm{~h}$ & sw & E. affinis & Arthropoda & Temoridae & crust \\
\hline Naphthalene & 2-MethyInaphthalene & LC50 & $1499 \mathrm{ug} / \mathrm{L}$ & $24 \mathrm{~h}$ & sw & E. affinis & Arthropoda & Temoridae & crust \\
\hline Naphthalene & Naphthalene & LC50 & 3798 ug/L & $24 \mathrm{~h}$ & sw & E. affinis & Arthropoda & Temoridae & crust \\
\hline PAH 2-3 ring & Fluorene & EC50 & $69.98 \mathrm{umol} / \mathrm{L}$ & $48 \mathrm{~h}$ & sw & O. davisae & Arthropoda & Oithonidae & crust \\
\hline PAH 2-3 ring & Fluorene & EC50 & $10.83 \mathrm{umol} / \mathrm{L}$ & $48 \mathrm{~h}$ & sw & O. davisae & Arthropoda & Oithonidae & crust \\
\hline PAH 2-3 ring & Phenanthrene & EC50 & $3.58 \mathrm{umol} / \mathrm{L}$ & $48 \mathrm{~h}$ & sw & O. davisae & Arthropoda & Oithonidae & crust \\
\hline PAH 2-3 ring & Phenanthrene & EC50 & $2.93 \mathrm{umol} / \mathrm{L}$ & $48 \mathrm{~h}$ & sw & O. davisae & Arthropoda & Oithonidae & crust \\
\hline PAH 2-3 ring & Phenanthrene & LC50 & $0.89 \mathrm{mg} / \mathrm{L}$ & $96 \mathrm{~h}$ & sw & R. propinqua & Arthropoda & Diosaccidae & crust \\
\hline PAH 2-3 ring & Phenanthrene & LC50 & $0.64 \mathrm{mg} / \mathrm{L}$ & $96 \mathrm{~h}$ & sw & Quinquelaophonte sp. & Arthropoda & Laophontidae & crust \\
\hline PAH 2-3 ring & Phenanthrene & LC50 & $0.75 \mathrm{mg} / \mathrm{L}$ & $96 \mathrm{~h}$ & sw & Quinquelaophonte sp. & Arthropoda & Laophontidae & crust \\
\hline PAH 2-3 ring & Phenanthrene & LC50 & $0.79 \mathrm{mg} / \mathrm{L}$ & $96 \mathrm{~h}$ & SW & Quinquelaophonte $s p$. & Arthropoda & Laophontidae & crust \\
\hline
\end{tabular}




\begin{tabular}{|c|c|c|c|c|c|c|c|c|c|}
\hline EIF group & EIF substance & Endp. & Eff. conc. & Obs. dur. & $\begin{array}{l}\text { Test } \\
\text { medium }\end{array}$ & Latin name & Phylum / division & Family & $\begin{array}{l}\text { Species } \\
\text { group }\end{array}$ \\
\hline PAH 4+ ring & Fluoranthene & EC50 & $0.66 \mathrm{umol} / \mathrm{L}$ & $48 \mathrm{~h}$ & sw & O. davisae & Arthropoda & Oithonidae & crust \\
\hline PAH 4+ ring & Fluoranthene & EC50 & $0.97 \mathrm{umol} / \mathrm{L}$ & $48 \mathrm{~h}$ & SW & O. davisae & Arthropoda & Oithonidae & crust \\
\hline PAH 4+ ring & Pyrene & EC50 & $0.53 \mathrm{umol} / \mathrm{L}$ & $48 \mathrm{~h}$ & sW & O. davisae & Arthropoda & Oithonidae & crust \\
\hline PAH 4+ ring & Pyrene & EC50 & $60.76 \mathrm{umol} / \mathrm{L}$ & $48 \mathrm{~h}$ & SW & O. davisae & Arthropoda & Oithonidae & crust \\
\hline Phenol C0-C3 & Phenol & LC50 & $37 \mathrm{mg} / \mathrm{L}$ & $96 \mathrm{~h}$ & sW & N. spinipes & Arthropoda & Ameiridae & crust \\
\hline Phenol C0-C3 & Phenol & LC50 & $32268.9 \mathrm{ug} / \mathrm{L}$ & $24 \mathrm{~h}$ & SW & A. clausi & Arthropoda & Acartiidae & crust \\
\hline Phenol C0-C3 & Phenol & LC50 & 1825.72 uM & $24 \mathrm{~h}$ & SW & T. battagliai & Arthropoda & Tisbidae & crust \\
\hline Phenol C0-C3 & Phenol & EC50 & $13 \mathrm{mg} / \mathrm{L}$ & $48 \mathrm{~h}$ & SW & A. sinjiensis & Arthropoda & Acartiidae & crust \\
\hline Phenol C0-C3 & Phenol & EC50 & $49 \mathrm{mg} / \mathrm{L}$ & $24 \mathrm{~h}$ & SW & A. sinjiensis & Arthropoda & Acartiidae & crust \\
\hline Phenol C0-C3 & Phenol & EC50 & $20 \mathrm{mg} / \mathrm{L}$ & $48 \mathrm{~h}$ & sW & A. sinjiensis & Arthropoda & Acartiidae & crust \\
\hline Phenol C4-C5 & 4-tert-Butylphenol & LC50 & $22 \mathrm{mg} / \mathrm{L}$ & $96 \mathrm{~h}$ & SW & T. japonicus & Arthropoda & Harpacticidae & crust \\
\hline Phenol C6+ & 4-tert-Octylphenol & LC50 & $0.42 \mathrm{mg} / \mathrm{L}$ & $48 \mathrm{~h}$ & SW & A. tonsa & Arthropoda & Acartiidae & crust \\
\hline Organic acid & Acetic acid & LC50 & $47 \mathrm{mg} / \mathrm{L}$ & $24 \mathrm{~h}$ & FW & D. magna & Arthropoda & Daphniidae & crust \\
\hline Organic acid & Acetic acid & EC50 & $6000 \mathrm{mg} / \mathrm{L}$ & $24 \mathrm{~h}$ & FW & D. magna & Arthropoda & Daphniidae & crust \\
\hline Organic acid & Acetic acid & LC50 & $426 \mathrm{mg} / \mathrm{L}$ & $100 \mathrm{~h}$ & FW & D. magna & Arthropoda & Daphniidae & crust \\
\hline Organic acid & Acetic acid & EC50 & $76000 \mathrm{ug} / \mathrm{L}$ & $1 \mathrm{~h}$ & FW & D. magna & Arthropoda & Daphniidae & crust \\
\hline Organic acid & Acetic acid & EC50 & $71000 \mathrm{ug} / \mathrm{L}$ & $24 \mathrm{~h}$ & FW & D. magna & Arthropoda & Daphniidae & crust \\
\hline Organic acid & Acetic acid & EC50 & $65000 \mathrm{ug} / \mathrm{L}$ & $48 \mathrm{~h}$ & FW & D. magna & Arthropoda & Daphniidae & crust \\
\hline Organic acid & Acetic acid & LC50 & $163.72 \mathrm{mg} / \mathrm{L}$ & $96 \mathrm{~h}$ & FW & M. micrura & Arthropoda & Moinidae & crust \\
\hline Organic acid & Acetic acid & EC50 & $6000 \mathrm{mg} / \mathrm{L}$ & $24 \mathrm{~h}$ & $\mathrm{FW}$ & D. magna & Arthropoda & Daphniidae & crust \\
\hline Organic acid & Acetic acid & LC50 & $47 \mathrm{mg} / \mathrm{L}$ & $24 \mathrm{~h}$ & FW & D. magna & Arthropoda & Daphniidae & crust \\
\hline Organic acid & Acetic acid & EC50 & $65000 \mathrm{ug} / \mathrm{L}$ & $48 \mathrm{~h}$ & FW & D. magna & Arthropoda & Daphniidae & crust \\
\hline Organic acid & Acetic acid & EC50 & $71000 \mathrm{ug} / \mathrm{L}$ & $24 \mathrm{~h}$ & FW & D. magna & Arthropoda & Daphniidae & crust \\
\hline Organic acid & Acetic acid & LC50 & $180000 \mathrm{ug} / \mathrm{L}$ & $48 \mathrm{~h}$ & SW & C. maenas & Arthropoda & Portunidae & crust \\
\hline Organic acid & Acetic acid & LC50 & NR ug/L & $48 \mathrm{~h}$ & SW & C. crangon & Arthropoda & Crangonidae & crust \\
\hline Organic acid & Acetic acid & LC50 & $158 \mathrm{mg} / \mathrm{L}$ & $96 \mathrm{~h}$ & SW & C. septemspinosa & Arthropoda & Crangonidae & crust \\
\hline Organic acid & Acetic acid & LC50 & $116 \mathrm{mg} / \mathrm{L}$ & $14 \mathrm{~d}$ & SW & C. septemspinosa & Arthropoda & Crangonidae & crust \\
\hline Organic acid & Acetic acid & LC50 & $50.1 \mathrm{ul} / \mathrm{L}$ & $48 \mathrm{~h}$ & SW & Artemia $s p$. & Arthropoda & Artemiidae & crust \\
\hline Organic acid & Acetic acid & LC50 & $117.6 \mathrm{ul} / \mathrm{L}$ & $48 \mathrm{~h}$ & SW & Artemia $s p$. & Arthropoda & Artemiidae & crust \\
\hline Organic acid & Acetic acid & LC50 & $132 \mathrm{ul} / \mathrm{L}$ & $48 \mathrm{~h}$ & SW & Artemia sp. & Arthropoda & Artemiidae & crust \\
\hline
\end{tabular}

60 of 84 | Wageningen Marine Research report c080/18 


\begin{tabular}{|c|c|c|c|c|c|c|c|c|c|}
\hline EIF group & EIF substance & Endp. & Eff. conc. & Obs. dur. & $\begin{array}{l}\text { Test } \\
\text { medium }\end{array}$ & Latin name & Phylum / division & Family & $\begin{array}{l}\text { Species } \\
\text { group }\end{array}$ \\
\hline Organic acid & Acetic acid & LC50 & $90.1 \mathrm{ul} / \mathrm{L}$ & $24 \mathrm{~h}$ & sw & Artemia sp. & Arthropoda & Artemiidae & crust \\
\hline Organic acid & Acetic acid & LC50 & $119 \mathrm{ul} / \mathrm{L}$ & $24 \mathrm{~h}$ & sW & Artemia sp. & Arthropoda & Artemiidae & crust \\
\hline Organic acid & Acetic acid & LC50 & $63 \mathrm{ul} / \mathrm{L}$ & $24 \mathrm{~h}$ & sw & Artemia sp. & Arthropoda & Artemiidae & crust \\
\hline Organic acid & Acetic acid & LC50 & $60.5 \mathrm{ul} / \mathrm{L}$ & $24 \mathrm{~h}$ & sw & Artemia sp. & Arthropoda & Artemiidae & crust \\
\hline Organic acid & Acetic acid & LC50 & $52.2 \mathrm{ul} / \mathrm{L}$ & $48 \mathrm{~h}$ & sw & Artemia sp. & Arthropoda & Artemiidae & crust \\
\hline Organic acid & Acetic acid & EC50 & $65.2 \mathrm{ul} / \mathrm{L}$ & $1 \mathrm{~h}$ & sw & Artemia sp. & Arthropoda & Artemiidae & crust \\
\hline Organic acid & Acetic acid & LC50 & $70 \mathrm{ul} / \mathrm{L}$ & $48 \mathrm{~h}$ & sw & Artemia sp. & Arthropoda & Artemiidae & crust \\
\hline Organic acid & Acetic acid & LC50 & $90.8 \mathrm{ul} / \mathrm{L}$ & $24 \mathrm{~h}$ & sw & Artemia sp. & Arthropoda & Artemiidae & crust \\
\hline Organic acid & Acetic acid & LC50 & $134 \mathrm{ul} / \mathrm{L}$ & $24 \mathrm{~h}$ & sw & Artemia sp. & Arthropoda & Artemiidae & crust \\
\hline Organic acid & Acetic acid & LC50 & $85.8 \mathrm{ul} / \mathrm{L}$ & $48 \mathrm{~h}$ & sw & Artemia sp. & Arthropoda & Artemiidae & crust \\
\hline Organic acid & Acetic acid & EC50 & $103 \mathrm{ul} / \mathrm{L}$ & $1 \mathrm{~h}$ & sw & Artemia sp. & Arthropoda & Artemiidae & crust \\
\hline Organic acid & Acetic acid & EC50 & $142 \mathrm{ul} / \mathrm{L}$ & $1 \mathrm{~h}$ & sw & Artemia sp. & Arthropoda & Artemiidae & crust \\
\hline Organic acid & Acetic acid & LC50 & $85.8 \mathrm{ul} / \mathrm{L}$ & $48 \mathrm{~h}$ & sW & Artemia sp. & Arthropoda & Artemiidae & crust \\
\hline Organic acid & Acetic acid & LC50 & $117.6 \mathrm{ul} / \mathrm{L}$ & $48 \mathrm{~h}$ & sw & Artemia sp. & Arthropoda & Artemiidae & crust \\
\hline Organic acid & Acetic acid & LC50 & $132 \mathrm{ul} / \mathrm{L}$ & $48 \mathrm{~h}$ & sw & Artemia sp. & Arthropoda & Artemiidae & crust \\
\hline Organic acid & Acetic acid & LC50 & $70 \mathrm{ul} / \mathrm{L}$ & $48 \mathrm{~h}$ & sw & Artemia sp. & Arthropoda & Artemiidae & crust \\
\hline Organic acid & Acetic acid & LC50 & $90.1 \mathrm{ul} / \mathrm{L}$ & $24 \mathrm{~h}$ & sw & Artemia sp. & Arthropoda & Artemiidae & crust \\
\hline Organic acid & Acetic acid & LC50 & $63 \mathrm{ul} / \mathrm{L}$ & $24 \mathrm{~h}$ & SW & Artemia sp. & Arthropoda & Artemiidae & crust \\
\hline Organic acid & Acetic acid & LC50 & $134 \mathrm{ul} / \mathrm{L}$ & $24 \mathrm{~h}$ & sw & Artemia sp. & Arthropoda & Artemiidae & crust \\
\hline Organic acid & Acetic acid & LC50 & $90.8 \mathrm{ul} / \mathrm{L}$ & $24 \mathrm{~h}$ & sW & Artemia sp. & Arthropoda & Artemiidae & crust \\
\hline Organic acid & Acetic acid & LC50 & $60.5 \mathrm{ul} / \mathrm{L}$ & $24 \mathrm{~h}$ & sw & Artemia sp. & Arthropoda & Artemiidae & crust \\
\hline Organic acid & Acetic acid & LC50 & $50.1 \mathrm{ul} / \mathrm{L}$ & $48 \mathrm{~h}$ & sw & Artemia sp. & Arthropoda & Artemiidae & crust \\
\hline Organic acid & Acetic acid & LC50 & $119 \mathrm{ul} / \mathrm{L}$ & $24 \mathrm{~h}$ & sw & Artemia sp. & Arthropoda & Artemiidae & crust \\
\hline Organic acid & Butyric acid & LC50 & $61000 \mathrm{ug} / \mathrm{L}$ & $48 \mathrm{~h}$ & FW & D. magna & Arthropoda & Daphniidae & crust \\
\hline Organic acid & Butyric acid & EC50 & $1950 \mathrm{mg} / \mathrm{L}$ & $24 \mathrm{~h}$ & FW & D. magna & Arthropoda & Daphniidae & crust \\
\hline Organic acid & Butyric acid & LC50 & $2750 \mathrm{mg} / \mathrm{L}$ & $24 \mathrm{~h}$ & $\mathrm{FW}$ & D. magna & Arthropoda & Daphniidae & crust \\
\hline Organic acid & Butyric acid & EC50 & $1950 \mathrm{mg} / \mathrm{L}$ & $24 \mathrm{~h}$ & FW & D. magna & Arthropoda & Daphniidae & crust \\
\hline Organic acid & Butyric acid & LC50 & $61000 \mathrm{ug} / \mathrm{L}$ & $48 \mathrm{~h}$ & FW & D. magna & Arthropoda & Daphniidae & crust \\
\hline Organic acid & Butyric acid & LC50 & $2750 \mathrm{mg} / \mathrm{L}$ & $24 \mathrm{~h}$ & FW & D. magna & Arthropoda & Daphniidae & crust \\
\hline
\end{tabular}




\begin{tabular}{|c|c|c|c|c|c|c|c|c|c|}
\hline EIF group & EIF substance & Endp. & Eff. conc. & Obs. dur. & $\begin{array}{l}\text { Test } \\
\text { medium }\end{array}$ & Latin name & Phylum / division & Family & $\begin{array}{l}\text { Species } \\
\text { group }\end{array}$ \\
\hline Organic acid & Formic acid & EC50 & $151200 \mathrm{ug} / \mathrm{L}$ & $48 \mathrm{~h}$ & $\mathrm{FW}$ & D. magna & Arthropoda & Daphniidae & crust \\
\hline Organic acid & Formic acid & EC50 & $679 \mathrm{mg} / \mathrm{L}$ & $24 \mathrm{~h}$ & FW & D. magna & Arthropoda & Daphniidae & crust \\
\hline Organic acid & Formic acid & EC50 & $68 \mathrm{mg} / \mathrm{L}$ & $24 \mathrm{~h}$ & $\mathrm{FW}$ & D. magna & Arthropoda & Daphniidae & crust \\
\hline Organic acid & Formic acid & EC50 & $151200 \mathrm{ug} / \mathrm{L}$ & $48 \mathrm{~h}$ & $\mathrm{FW}$ & D. magna & Arthropoda & Daphniidae & crust \\
\hline Organic acid & Formic acid & EC50 & $679 \mathrm{mg} / \mathrm{L}$ & $24 \mathrm{~h}$ & $\mathrm{FW}$ & D. magna & Arthropoda & Daphniidae & crust \\
\hline Organic acid & Formic acid & EC50 & $68 \mathrm{mg} / \mathrm{L}$ & $24 \mathrm{~h}$ & FW & D. magna & Arthropoda & Daphniidae & crust \\
\hline Organic acid & Formic acid & LC50 & NR ug/L & $48 \mathrm{~h}$ & sW & C. maenas & Arthropoda & Portunidae & crust \\
\hline Organic acid & Propionic acid & LC50 & $50000 \mathrm{ug} / \mathrm{L}$ & $48 \mathrm{~h}$ & $\mathrm{FW}$ & D. magna & Arthropoda & Daphniidae & crust \\
\hline Organic acid & Propionic acid & EC50 & $22.7 \mathrm{ppm}$ & $48 \mathrm{~h}$ & $\mathrm{FW}$ & D. magna & Arthropoda & Daphniidae & crust \\
\hline Organic acid & Propionic acid & LC50 & $50000 \mathrm{ug} / \mathrm{L}$ & $48 \mathrm{~h}$ & FW & D. magna & Arthropoda & Daphniidae & crust \\
\hline Organic acid & Propionic acid & EC50 & $22.7 \mathrm{ppm}$ & $48 \mathrm{~h}$ & FW & D. magna & Arthropoda & Daphniidae & crust \\
\hline Organic acid & Sodium acetate & LC50 & $7170 \mathrm{mg} / \mathrm{L}$ & $24 \mathrm{~h}$ & $\mathrm{FW}$ & D. magna & Arthropoda & Daphniidae & crust \\
\hline Organic acid & Sodium acetate & LC50 & $7170 \mathrm{mg} / \mathrm{L}$ & $24 \mathrm{~h}$ & FW & D. magna & Arthropoda & Daphniidae & crust \\
\hline Organic acid & Sodium butyrate & EC50 & $1950000 \mathrm{ug} / \mathrm{L}$ & $24 \mathrm{~h}$ & FW & D. magna & Arthropoda & Daphniidae & crust \\
\hline Organic acid & Sodium butyrate & EC50 & $1950000 \mathrm{ug} / \mathrm{L}$ & $24 \mathrm{~h}$ & $\mathrm{FW}$ & D. magna & Arthropoda & Daphniidae & crust \\
\hline Organic acid & Sodium formate & LC50 & $1860 \mathrm{mg} / \mathrm{L}$ & $48 \mathrm{~h}$ & $\mathrm{FW}$ & C. dubia & Arthropoda & Daphniidae & crust \\
\hline Organic acid & Sodium formate & LC50 & $1400 \mathrm{mg} / \mathrm{L}$ & $48 \mathrm{~h}$ & FW & C. dubia & Arthropoda & Daphniidae & crust \\
\hline Organic acid & Sodium formate & LC50 & $1400 \mathrm{mg} / \mathrm{L}$ & $48 \mathrm{~h}$ & $\mathrm{FW}$ & C. dubia & Arthropoda & Daphniidae & crust \\
\hline Organic acid & Sodium formate & LC50 & $1860 \mathrm{mg} / \mathrm{L}$ & $48 \mathrm{~h}$ & FW & C. dubia & Arthropoda & Daphniidae & crust \\
\hline Organic acid & Sodium hexanoate & EC50 & $1600000 \mathrm{ug} / \mathrm{L}$ & $24 \mathrm{~h}$ & FW & D. magna & Arthropoda & Daphniidae & crust \\
\hline Organic acid & Sodium hexanoate & EC50 & $1600000 \mathrm{ug} / \mathrm{L}$ & $24 \mathrm{~h}$ & FW & D. magna & Arthropoda & Daphniidae & crust \\
\hline Organic acid & Sodium valerate & EC50 & $1800000 \mathrm{ug} / \mathrm{L}$ & $24 \mathrm{~h}$ & FW & D. magna & Arthropoda & Daphniidae & crust \\
\hline Organic acid & Sodium valerate & EC50 & $1800000 \mathrm{ug} / \mathrm{L}$ & $24 \mathrm{~h}$ & FW & D. magna & Arthropoda & Daphniidae & crust \\
\hline Organic acid & Valeric acid & LC50 & $45000 \mathrm{ug} / \mathrm{L}$ & $48 \mathrm{~h}$ & FW & D. magna & Arthropoda & Daphniidae & crust \\
\hline Organic acid & Valeric acid & LC50 & $45000 \mathrm{ug} / \mathrm{L}$ & $48 \mathrm{~h}$ & $\mathrm{FW}$ & D. magna & Arthropoda & Daphniidae & crust \\
\hline Arsenic & As & LC50 & $508 \mathrm{ug} / \mathrm{L}$ & $96 \mathrm{~h}$ & SW & A. clausi & Arthropoda & Acartiidae & crust \\
\hline Arsenic & As & LC50 & $508 \mathrm{ug} / \mathrm{L}$ & $96 \mathrm{~h}$ & sw & A. clausi & Arthropoda & Acartiidae & crust \\
\hline Cadmium & $\mathrm{Cd}$ & LC50 & 337 ug/L & $96 \mathrm{~h}$ & SW & A. tonsa & Arthropoda & Acartiidae & crust \\
\hline Cadmium & $\mathrm{Cd}$ & LC50 & $220 \mathrm{ug} / \mathrm{L}$ & $96 \mathrm{~h}$ & SW & A. tonsa & Arthropoda & Acartiidae & crust \\
\hline Cadmium & $\mathrm{Cd}$ & LC50 & $190 \mathrm{ug} / \mathrm{L}$ & $96 \mathrm{~h}$ & SW & A. tonsa & Arthropoda & Acartiidae & crust \\
\hline
\end{tabular}

62 of 84 | Wageningen Marine Research report C080/18 


\begin{tabular}{|c|c|c|c|c|c|c|c|c|c|}
\hline EIF group & EIF substance & Endp. & Eff. conc. & Obs. dur. & $\begin{array}{l}\text { Test } \\
\text { medium }\end{array}$ & Latin name & Phylum / division & Family & $\begin{array}{l}\text { Species } \\
\text { group }\end{array}$ \\
\hline Cadmium & $\mathrm{Cd}$ & LC50 & $122 \mathrm{ug} / \mathrm{L}$ & $96 \mathrm{~h}$ & sw & A. tonsa & Arthropoda & Acartiidae & crust \\
\hline Cadmium & $\mathrm{Cd}$ & LC50 & $90 \mathrm{ug} / \mathrm{L}$ & $96 \mathrm{~h}$ & SW & A. tonsa & Arthropoda & Acartiidae & crust \\
\hline Cadmium & $\mathrm{Cd}$ & LC50 & $151 \mathrm{ug} / \mathrm{L}$ & $96 \mathrm{~h}$ & sW & A. tonsa & Arthropoda & Acartiidae & crust \\
\hline Cadmium & $\mathrm{Cd}$ & LC50 & $29 \mathrm{ug} / \mathrm{L}$ & $96 \mathrm{~h}$ & SW & A. tonsa & Arthropoda & Acartiidae & crust \\
\hline Cadmium & $\mathrm{Cd}$ & LC50 & $380 \mathrm{ug} / \mathrm{L}$ & $96 \mathrm{~h}$ & sW & A. tonsa & Arthropoda & Acartiidae & crust \\
\hline Cadmium & $\mathrm{Cd}$ & LC50 & $93 \mathrm{ug} / \mathrm{L}$ & $96 \mathrm{~h}$ & SW & A. tonsa & Arthropoda & Acartiidae & crust \\
\hline Chromium & $\mathrm{Cr}$ & LC50 & $16990 \mathrm{ug} / \mathrm{L}$ & $48 \mathrm{~h}$ & SW & A. clausi & Arthropoda & Acartiidae & crust \\
\hline Chromium & $\mathrm{Cr}$ & LC50 & $8830 \mathrm{ug} / \mathrm{L}$ & $48 \mathrm{~h}$ & SW & A. clausi & Arthropoda & Acartiidae & crust \\
\hline Chromium & $\mathrm{Cr}$ & LC50 & $16370 \mathrm{ug} / \mathrm{L}$ & $48 \mathrm{~h}$ & SW & A. clausi & Arthropoda & Acartiidae & crust \\
\hline Chromium & $\mathrm{Cr}$ & LC50 & $12260 \mathrm{ug} / \mathrm{L}$ & $48 \mathrm{~h}$ & sW & A. clausi & Arthropoda & Acartiidae & crust \\
\hline Chromium & $\mathrm{Cr}$ & LC50 & $11470 \mathrm{ug} / \mathrm{L}$ & $48 \mathrm{~h}$ & SW & A. clausi & Arthropoda & Acartiidae & crust \\
\hline Chromium & $\mathrm{Cr}$ & LC50 & $19270 \mathrm{ug} / \mathrm{L}$ & $48 \mathrm{~h}$ & SW & A. clausi & Arthropoda & Acartiidae & crust \\
\hline Copper & $\mathrm{Cu}$ & LC50 & $108.7 \mathrm{ug} / \mathrm{L}$ & $48 \mathrm{~h}$ & SW & A. tonsa & Arthropoda & Acartiidae & crust \\
\hline Lead & $\mathrm{Pb}$ & LC50 & $668 \mathrm{ug} / \mathrm{L}$ & $96 \mathrm{~h}$ & SW & A. clausi & Arthropoda & Acartiidae & crust \\
\hline Lead & $\mathrm{Pb}$ & LC50 & $668 \mathrm{ug} / \mathrm{L}$ & $96 \mathrm{~h}$ & SW & A. clausi & Arthropoda & Acartiidae & crust \\
\hline Mercury & $\mathrm{Hg}$ & LC50 & $19 \mathrm{ug} / \mathrm{L}$ & $48 \mathrm{~h}$ & SW & A. tonsa & Arthropoda & Acartiidae & crust \\
\hline Mercury & $\mathrm{Hg}$ & LC50 & $17 \mathrm{ug} / \mathrm{L}$ & $72 \mathrm{~h}$ & SW & A. tonsa & Arthropoda & Acartiidae & crust \\
\hline Mercury & $\mathrm{Hg}$ & LC50 & 17 ug/L & $48 \mathrm{~h}$ & SW & A. tonsa & Arthropoda & Acartiidae & crust \\
\hline Mercury & $\mathrm{Hg}$ & LC50 & $10 \mathrm{ug} / \mathrm{L}$ & $96 \mathrm{~h}$ & SW & A. tonsa & Arthropoda & Acartiidae & crust \\
\hline Mercury & $\mathrm{Hg}$ & LC50 & $13 \mathrm{ug} / \mathrm{L}$ & $72 \mathrm{~h}$ & SW & A. tonsa & Arthropoda & Acartiidae & crust \\
\hline Mercury & $\mathrm{Hg}$ & LC50 & 15 ug/L & $96 \mathrm{~h}$ & SW & A. tonsa & Arthropoda & Acartiidae & crust \\
\hline Mercury & $\mathrm{Hg}$ & LC50 & 14 ug/L & $96 \mathrm{~h}$ & SW & A. tonsa & Arthropoda & Acartiidae & crust \\
\hline Mercury & $\mathrm{Hg}$ & LC50 & $16 \mathrm{ug} / \mathrm{L}$ & $72 \mathrm{~h}$ & SW & A. tonsa & Arthropoda & Acartiidae & crust \\
\hline Mercury & $\mathrm{Hg}$ & LC50 & $19 \mathrm{ug} / \mathrm{L}$ & $48 \mathrm{~h}$ & SW & A. tonsa & Arthropoda & Acartiidae & crust \\
\hline Nickel & $\mathrm{Ni}$ & LC50 & $6000 \mathrm{ug} / \mathrm{L}$ & $96 \mathrm{~h}$ & SW & N. spinipes & Arthropoda & Ameiridae & crust \\
\hline Zinc & $\mathrm{Zn}$ & LC50 & $1860 \mathrm{ug} / \mathrm{L}$ & $24 \mathrm{~h}$ & SW & A. simplex & Arthropoda & Acartiidae & crust \\
\hline PLONOR 1 & Monoethylene glycol & EC50 & $>10 \mathrm{~g} / \mathrm{L}$ & $24 \mathrm{~h}$ & $\mathrm{FW}$ & D. magna & Arthropoda & Daphniidae & crust \\
\hline PLONOR 1 & Monoethylene glycol & LC50 & $>10000 \mathrm{mg} / \mathrm{L}$ & $24 \mathrm{~h}$ & FW & D. magna & Arthropoda & Daphniidae & crust \\
\hline PLONOR 1 & Monoethylene glycol & LC50 & $>10000000 \mathrm{ug} / \mathrm{L}$ & $24 \mathrm{~h}$ & FW & D. magna & Arthropoda & Daphniidae & crust \\
\hline PLONOR 1 & Monoethylene glycol & LC50 & $>10000000 \mathrm{ug} / \mathrm{L}$ & $48 \mathrm{~h}$ & FW & D. magna & Arthropoda & Daphniidae & crust \\
\hline
\end{tabular}




\begin{tabular}{|c|c|c|c|c|c|c|c|c|c|}
\hline EIF group & EIF substance & Endp. & Eff. conc. & Obs. dur. & $\begin{array}{l}\text { Test } \\
\text { medium }\end{array}$ & Latin name & Phylum / division & Family & $\begin{array}{l}\text { Species } \\
\text { group }\end{array}$ \\
\hline PLONOR 1 & Monoethylene glycol & LC50 & $51000000 \mathrm{ug} / \mathrm{L}$ & $48 \mathrm{~h}$ & $\mathrm{FW}$ & D. magna & Arthropoda & Daphniidae & crust \\
\hline PLONOR 1 & Monoethylene glycol & LC50 & $41100000 \mathrm{ug} / \mathrm{L}$ & $48 \mathrm{~h}$ & FW & D. magna & Arthropoda & Daphniidae & crust \\
\hline PLONOR 1 & Monoethylene glycol & LC50 & $47400000 \mathrm{ug} / \mathrm{L}$ & $48 \mathrm{~h}$ & FW & D. magna & Arthropoda & Daphniidae & crust \\
\hline PLONOR 1 & Monoethylene glycol & LC50 & $46300000 \mathrm{ug} / \mathrm{L}$ & $48 \mathrm{~h}$ & FW & D. magna & Arthropoda & Daphniidae & crust \\
\hline PLONOR 1 & Monoethylene glycol & LC50 & $57600000 \mathrm{ug} / \mathrm{L}$ & $48 \mathrm{~h}$ & FW & D. magna & Arthropoda & Daphniidae & crust \\
\hline PLONOR 1 & Monoethylene glycol & LC50 & $45500000 \mathrm{ug} / \mathrm{L}$ & $48 \mathrm{~h}$ & FW & D. magna & Arthropoda & Daphniidae & crust \\
\hline PLONOR 1 & Monoethylene glycol & LC50 & $51000000 \mathrm{ug} / \mathrm{L}$ & $48 \mathrm{~h}$ & FW & D. magna & Arthropoda & Daphniidae & crust \\
\hline PLONOR 1 & Monoethylene glycol & LC50 & $51100000 \mathrm{ug} / \mathrm{L}$ & $48 \mathrm{~h}$ & FW & D. magna & Arthropoda & Daphniidae & crust \\
\hline PLONOR 1 & Monoethylene glycol & LC50 & $29700000 \mathrm{ug} / \mathrm{L}$ & $48 \mathrm{~h}$ & FW & C. dubia & Arthropoda & Daphniidae & crust \\
\hline PLONOR 1 & Monoethylene glycol & LC50 & $22600000 \mathrm{ug} / \mathrm{L}$ & $48 \mathrm{~h}$ & FW & C. dubia & Arthropoda & Daphniidae & crust \\
\hline PLONOR 1 & Monoethylene glycol & LC50 & $25500000 \mathrm{ug} / \mathrm{L}$ & $48 \mathrm{~h}$ & FW & C. dubia & Arthropoda & Daphniidae & crust \\
\hline PLONOR 1 & Monoethylene glycol & LC50 & $25800000 \mathrm{ug} / \mathrm{L}$ & $48 \mathrm{~h}$ & $\mathrm{FW}$ & C. dubia & Arthropoda & Daphniidae & crust \\
\hline PLONOR 1 & Monoethylene glycol & LC50 & $13900000 \mathrm{ug} / \mathrm{L}$ & $48 \mathrm{~h}$ & FW & C. dubia & Arthropoda & Daphniidae & crust \\
\hline PLONOR 1 & Monoethylene glycol & LC50 & $10500000 \mathrm{ug} / \mathrm{L}$ & $48 \mathrm{~h}$ & FW & C. dubia & Arthropoda & Daphniidae & crust \\
\hline PLONOR 1 & Monoethylene glycol & LC50 & $6900000 \mathrm{ug} / \mathrm{L}$ & $48 \mathrm{~h}$ & $\mathrm{FW}$ & C. dubia & Arthropoda & Daphniidae & crust \\
\hline PLONOR 1 & Monoethylene glycol & LC50 & $10000000 \mathrm{ug} / \mathrm{L}$ & $48 \mathrm{~h}$ & FW & C. dubia & Arthropoda & Daphniidae & crust \\
\hline PLONOR 1 & Monoethylene glycol & LC50 & $55000000 \mathrm{ug} / \mathrm{L}$ & $24 \mathrm{~h}$ & FW & D. magna & Arthropoda & Daphniidae & crust \\
\hline PLONOR 1 & Monoethylene glycol & LC50 & $41100000 \mathrm{ug} / \mathrm{L}$ & $24 \mathrm{~h}$ & FW & D. magna & Arthropoda & Daphniidae & crust \\
\hline PLONOR 1 & Monoethylene glycol & LC50 & $50300000 \mathrm{ug} / \mathrm{L}$ & $24 \mathrm{~h}$ & FW & D. magna & Arthropoda & Daphniidae & crust \\
\hline PLONOR 1 & Monoethylene glycol & LC50 & $51000000 \mathrm{ug} / \mathrm{L}$ & $48 \mathrm{~h}$ & $\mathrm{FW}$ & D. magna & Arthropoda & Daphniidae & crust \\
\hline PLONOR 1 & Monoethylene glycol & LC50 & $41000000 \mathrm{ug} / \mathrm{L}$ & $48 \mathrm{~h}$ & FW & D. magna & Arthropoda & Daphniidae & crust \\
\hline PLONOR 1 & Monoethylene glycol & LC50 & $47400000 \mathrm{ug} / \mathrm{L}$ & $48 \mathrm{~h}$ & FW & D. magna & Arthropoda & Daphniidae & crust \\
\hline PLONOR 1 & Monoethylene glycol & EC50 & $1200000 \mathrm{umol} / \mathrm{L}$ & $24 \mathrm{~h}$ & FW & D. magna & Arthropoda & Daphniidae & crust \\
\hline PLONOR 1 & Monoethylene glycol & LC50 & $34440000 \mathrm{ug} / \mathrm{L}$ & $48 \mathrm{~h}$ & FW & C. dubia & Arthropoda & Daphniidae & crust \\
\hline PLONOR 1 & Monoethylene glycol & LC50 & $13140000 \mathrm{ug} / \mathrm{L}$ & $48 \mathrm{~h}$ & FW & C. dubia & Arthropoda & Daphniidae & crust \\
\hline PLONOR 1 & Monoethylene glycol & EC50 & $973.2 \mathrm{mM}$ & $24 \mathrm{~h}$ & FW & D. pulex & Arthropoda & Daphniidae & crust \\
\hline PLONOR 1 & Monoethylene glycol & EC50 & $782.7 \mathrm{mM}$ & $24 \mathrm{~h}$ & $\mathrm{FW}$ & D. magna & Arthropoda & Daphniidae & crust \\
\hline PLONOR 2 & Methanol & LC50 & $12000000 \mathrm{ug} / \mathrm{L}$ & $96 \mathrm{~h}$ & SW & N. spinipes & Arthropoda & Ameiridae & crust \\
\hline PLONOR 2 & Methanol & LC50 & $12000000 \mathrm{ug} / \mathrm{L}$ & $96 \mathrm{~h}$ & SW & N. spinipes & Arthropoda & Ameiridae & crust \\
\hline BTEX & Ethyl-benzene & EC50 & 4900 ug/L & $72 \mathrm{~h}$ & SW & S. costatum & Bacillariophyta & Skeletonemaceae & alg \\
\hline
\end{tabular}

64 of 84 | Wageningen Marine Research report c080/18 


\begin{tabular}{|c|c|c|c|c|c|c|c|c|c|}
\hline EIF group & EIF substance & Endp. & Eff. conc. & Obs. dur. & $\begin{array}{l}\text { Test } \\
\text { medium }\end{array}$ & Latin name & Phylum / division & Family & $\begin{array}{l}\text { Species } \\
\text { group }\end{array}$ \\
\hline BTEX & Ethyl-benzene & EC50 & 8000 ug/L & $24 \mathrm{~h}$ & sw & S. costatum & Bacillariophyta & Skeletonemaceae & alg \\
\hline BTEX & Ethyl-benzene & EC50 & 7500 ug/L & $48 \mathrm{~h}$ & sW & S. costatum & Bacillariophyta & Skeletonemaceae & alg \\
\hline BTEX & Ethyl-benzene & EC50 & 7700 ug/L & $96 \mathrm{~h}$ & sw & S. costatum & Bacillariophyta & Skeletonemaceae & alg \\
\hline $\begin{array}{l}\text { Aliphatic } \\
\text { hydrocarbons }\end{array}$ & Heptane & EC50 & $1500 \mathrm{ug} / \mathrm{L}$ & $8 \mathrm{~h}$ & sW & Algae & & & alg \\
\hline Naphthalene & Naphthalene & EC50 & $2000 \mathrm{ug} / \mathrm{L}$ & $24 \mathrm{~h}$ & sW & T. pseudonana & Bacillariophyta & Thalassiosiraceae & alg \\
\hline PAH 2-3 ring & Acenaphthene & EC50 & $0.5 \mathrm{ppm}$ & $96 \mathrm{~h}$ & sW & S. costatum & Bacillariophyta & Skeletonemaceae & alg \\
\hline PAH 2-3 ring & Acenaphthene & EC50 & $>1 \mathrm{ppm}$ & $48 \mathrm{~h}$ & sw & S. costatum & Bacillariophyta & Skeletonemaceae & alg \\
\hline PAH 2-3 ring & Acenaphthene & EC50 & $0.5 \mathrm{ppm}$ & $96 \mathrm{~h}$ & sw & S. costatum & Bacillariophyta & Skeletonemaceae & alg \\
\hline PAH 2-3 ring & Acenaphthene & EC50 & $>1 \mathrm{ppm}$ & $24 \mathrm{~h}$ & sW & S. costatum & Bacillariophyta & Skeletonemaceae & alg \\
\hline PAH 4+ ring & Fluoranthene & EC50 & $41.3 \mathrm{ppm}$ & $72 \mathrm{~h}$ & sw & S. costatum & Bacillariophyta & Skeletonemaceae & alg \\
\hline Phenol C0-C3 & Phenol & EC50 & $49600 \mathrm{ug} / \mathrm{L}$ & $5 d$ & SW & S. costatum & Bacillariophyta & Skeletonemaceae & alg \\
\hline Phenol C0-C3 & Phenol & EC50 & $49800 \mathrm{ug} / \mathrm{L}$ & $5 d$ & sW & S. costatum & Bacillariophyta & Skeletonemaceae & alg \\
\hline Phenol C4-C5 & 4-n-Pentylphenol & EC50 & $2600 \mathrm{ug} / \mathrm{L}$ & $72 \mathrm{~h}$ & FW & C. pyrenoidosa & Chlorophyta & Oocystaceae & alg \\
\hline Phenol C6+ & 4-tert-Octylphenol & EC50 & $140 \mathrm{ug} / \mathrm{L}$ & $72 \mathrm{~h}$ & sw & S. costatum & Bacillariophyta & Skeletonemaceae & alg \\
\hline Organic acid & Acetic acid & EC50 & $73900 \mathrm{ug} / \mathrm{L}$ & $96 \mathrm{~h}$ & FW & N. seminulum & Bacillariophyta & Naviculaceae & alg \\
\hline Organic acid & Acetic acid & EC50 & $73400 \mathrm{ug} / \mathrm{L}$ & $96 \mathrm{~h}$ & $\mathrm{FW}$ & N. seminulum & Bacillariophyta & Naviculaceae & alg \\
\hline Organic acid & Acetic acid & EC50 & $156 \mathrm{mg} / \mathrm{L}$ & $24 \mathrm{~h}$ & FW & Chlorophyta & Chlorophyta & & alg \\
\hline Organic acid & Acetic acid & EC50 & $73400 \mathrm{ug} / \mathrm{L}$ & $96 \mathrm{~h}$ & FW & N. seminulum & Bacillariophyta & Naviculaceae & alg \\
\hline Organic acid & Acetic acid & EC50 & $73900 \mathrm{ug} / \mathrm{L}$ & $96 \mathrm{~h}$ & $\mathrm{FW}$ & N. seminulum & Bacillariophyta & Naviculaceae & alg \\
\hline Organic acid & Butyric acid & EC50 & $180 \mathrm{mg} / \mathrm{L}$ & $24 \mathrm{~h}$ & FW & Chlorophyta & Chlorophyta & & alg \\
\hline Arsenic & As & EC50 & $31200 \mathrm{ug} / \mathrm{L}$ & $96 \mathrm{~h}$ & FW & P. subcapitata & Chlorophyta & Scenedesmaceae & alg \\
\hline Arsenic & As & EC50 & $690 \mathrm{ug} / \mathrm{L}$ & $96 \mathrm{~h}$ & FW & P. subcapitata & Chlorophyta & Scenedesmaceae & alg \\
\hline Arsenic & As & EC50 & $31200 \mathrm{ug} / \mathrm{L}$ & $96 \mathrm{~h}$ & $\mathrm{FW}$ & P. subcapitata & Chlorophyta & Scenedesmaceae & alg \\
\hline Arsenic & As & EC50 & $690 \mathrm{ug} / \mathrm{L}$ & $96 \mathrm{~h}$ & FW & P. subcapitata & Chlorophyta & Scenedesmaceae & alg \\
\hline Arsenic & As & EC50 & $78.7 \mathrm{ug} / \mathrm{L}$ & $96 \mathrm{~h}$ & $\mathrm{FW}$ & S. acutus & Chlorophyta & Scenedesmaceae & alg \\
\hline Arsenic & As & EC50 & $159.3 \mathrm{ug} / \mathrm{L}$ & $96 \mathrm{~h}$ & FW & S. acutus & Chlorophyta & Scenedesmaceae & alg \\
\hline Cadmium & $\mathrm{Cd}$ & EC50 & $144 \mathrm{ug} / \mathrm{L}$ & $72 \mathrm{~h}$ & SW & S. costatum & Bacillariophyta & Skeletonemaceae & alg \\
\hline Chromium & $\mathrm{Cr}$ & EC50 & $3000 \mathrm{ug} / \mathrm{L}$ & $72 \mathrm{~h}$ & SW & Nitzschia sp. & Bacillariophyta & Bacillariaceae & alg \\
\hline Chromium & $\mathrm{Cr}$ & EC50 & $260 \mathrm{ug} / \mathrm{L}$ & $72 \mathrm{~h}$ & SW & Nitzschia sp. & Bacillariophyta & Bacillariaceae & alg \\
\hline
\end{tabular}




\begin{tabular}{|c|c|c|c|c|c|c|c|c|c|}
\hline EIF group & EIF substance & Endp. & Eff. conc. & Obs. dur. & $\begin{array}{l}\text { Test } \\
\text { medium }\end{array}$ & Latin name & Phylum / division & Family & $\begin{array}{l}\text { Species } \\
\text { group }\end{array}$ \\
\hline Chromium & $\mathrm{Cr}$ & LC50 & $0.35 \mathrm{mg} / \mathrm{L}$ & $48 \mathrm{~h}$ & sW & T. pseudonana & Bacillariophyta & Thalassiosiraceae & alg \\
\hline Chromium & $\mathrm{Cr}$ & LC50 & $0.48 \mathrm{mg} / \mathrm{L}$ & $48 \mathrm{~h}$ & sw & T. pseudonana & Bacillariophyta & Thalassiosiraceae & alg \\
\hline Chromium & $\mathrm{Cr}$ & LC50 & $0.6 \mathrm{mg} / \mathrm{L}$ & $48 \mathrm{~h}$ & sW & T. pseudonana & Bacillariophyta & Thalassiosiraceae & alg \\
\hline Copper & $\mathrm{Cu}$ & EC50 & $>3.9$ uM & $72 \mathrm{~h}$ & sw & S. costatum & Bacillariophyta & Skeletonemaceae & alg \\
\hline Lead & $\mathrm{Pb}$ & EC50 & $19.5 \mathrm{ug} / \mathrm{L}$ & $72 \mathrm{~h}$ & sw & S. costatum & Bacillariophyta & Skeletonemaceae & alg \\
\hline Mercury & $\mathrm{Hg}$ & LC50 & $0.088 \mathrm{mg} / \mathrm{L}$ & $48 \mathrm{~h}$ & SW & T. pseudonana & Bacillariophyta & Thalassiosiraceae & alg \\
\hline Mercury & $\mathrm{Hg}$ & LC50 & $0.075 \mathrm{mg} / \mathrm{L}$ & $48 \mathrm{~h}$ & sw & T. pseudonana & Bacillariophyta & Thalassiosiraceae & alg \\
\hline Mercury & $\mathrm{Hg}$ & LC50 & $0.03 \mathrm{mg} / \mathrm{L}$ & $48 \mathrm{~h}$ & SW & T. pseudonana & Bacillariophyta & Thalassiosiraceae & alg \\
\hline Mercury & $\mathrm{Hg}$ & LC50 & $0.049 \mathrm{mg} / \mathrm{L}$ & $48 \mathrm{~h}$ & sw & T. pseudonana & Bacillariophyta & Thalassiosiraceae & alg \\
\hline Mercury & $\mathrm{Hg}$ & LC50 & $0.095 \mathrm{mg} / \mathrm{L}$ & $48 \mathrm{~h}$ & sW & T. pseudonana & Bacillariophyta & Thalassiosiraceae & alg \\
\hline Mercury & $\mathrm{Hg}$ & LC50 & $>0.1 \mathrm{mg} / \mathrm{L}$ & $48 \mathrm{~h}$ & sw & T. pseudonana & Bacillariophyta & Thalassiosiraceae & alg \\
\hline Mercury & $\mathrm{Hg}$ & LC50 & $0.056 \mathrm{mg} / \mathrm{L}$ & $48 \mathrm{~h}$ & SW & T. pseudonana & Bacillariophyta & Thalassiosiraceae & alg \\
\hline Mercury & $\mathrm{Hg}$ & LC50 & $0.073 \mathrm{mg} / \mathrm{L}$ & $48 \mathrm{~h}$ & SW & T. pseudonana & Bacillariophyta & Thalassiosiraceae & alg \\
\hline Mercury & $\mathrm{Hg}$ & LC50 & $0.48 \mathrm{mg} / \mathrm{L}$ & $48 \mathrm{~h}$ & sw & T. pseudonana & Bacillariophyta & Thalassiosiraceae & alg \\
\hline Mercury & $\mathrm{Hg}$ & LC50 & $0.043 \mathrm{mg} / \mathrm{L}$ & $48 \mathrm{~h}$ & SW & T. pseudonana & Bacillariophyta & Thalassiosiraceae & alg \\
\hline Nickel & $\mathrm{Ni}$ & LC50 & $>10 \mathrm{mg} / \mathrm{L}$ & $48 \mathrm{~h}$ & sw & T. pseudonana & Bacillariophyta & Thalassiosiraceae & alg \\
\hline Nickel & $\mathrm{Ni}$ & LC50 & $0.9 \mathrm{mg} / \mathrm{L}$ & $48 \mathrm{~h}$ & sW & T. pseudonana & Bacillariophyta & Thalassiosiraceae & alg \\
\hline Nickel & $\mathrm{Ni}$ & LC50 & $>10 \mathrm{mg} / \mathrm{L}$ & $48 \mathrm{~h}$ & sw & T. pseudonana & Bacillariophyta & Thalassiosiraceae & alg \\
\hline Nickel & $\mathrm{Ni}$ & LC50 & $>10 \mathrm{mg} / \mathrm{L}$ & $48 \mathrm{~h}$ & SW & T. pseudonana & Bacillariophyta & Thalassiosiraceae & alg \\
\hline Nickel & $\mathrm{Ni}$ & LC50 & $0.4 \mathrm{mg} / \mathrm{L}$ & $48 \mathrm{~h}$ & sw & T. pseudonana & Bacillariophyta & Thalassiosiraceae & alg \\
\hline Nickel & $\mathrm{Ni}$ & LC50 & $0.18 \mathrm{mg} / \mathrm{L}$ & $48 \mathrm{~h}$ & SW & T. pseudonana & Bacillariophyta & Thalassiosiraceae & alg \\
\hline Nickel & $\mathrm{Ni}$ & LC50 & $>10 \mathrm{mg} / \mathrm{L}$ & $48 \mathrm{~h}$ & SW & T. pseudonana & Bacillariophyta & Thalassiosiraceae & alg \\
\hline Nickel & $\mathrm{Ni}$ & LC50 & $0.1 \mathrm{mg} / \mathrm{L}$ & $48 \mathrm{~h}$ & sW & T. pseudonana & Bacillariophyta & Thalassiosiraceae & alg \\
\hline Nickel & $\mathrm{Ni}$ & LC50 & $>10 \mathrm{mg} / \mathrm{L}$ & $48 \mathrm{~h}$ & SW & T. pseudonana & Bacillariophyta & Thalassiosiraceae & alg \\
\hline Nickel & $\mathrm{Ni}$ & LC50 & $>10 \mathrm{mg} / \mathrm{L}$ & $48 \mathrm{~h}$ & sw & T. pseudonana & Bacillariophyta & Thalassiosiraceae & alg \\
\hline Zinc & $\mathrm{Zn}$ & EC50 & $142 \mathrm{ug} / \mathrm{L}$ & $72 \mathrm{~h}$ & sW & S. costatum & Bacillariophyta & Skeletonemaceae & alg \\
\hline PLONOR 1 & Monoethylene Glycol & EC50 & $29900 \mathrm{mg} / \mathrm{l}^{7}$ & $72 \mathrm{~h}$ & sw & S. costatum & Bacillariophyta & Skeletonemaceae & alg \\
\hline
\end{tabular}

${ }^{7}$ No data from the US EPA ECOTOX database available for algae for this substance. Information from an informal source was used: Preliminary data summary airport deicing operations (revised); EPA; https://books.google.nl/books?id=MPplU17g1EsC\&pg=SA9-PA51\&lpg=SA9-PA51\&dq=ward+1992+Skeletonema+costatum+Mysidopsis+bahia\&source=bl\&ots=6mgLe- OVi\&sig=MpQcDd11fFAyNsPFwBcs1U9uJc\&hl=en\&sa=X\&ved=0ahUKEwjV_bHR1NvWAhWOb1AKHcfpAVIQ6AEINjAF\#v=onepage\&q=29\%2C900\&f=false 


\begin{tabular}{|c|c|c|c|c|c|c|c|c|c|}
\hline EIF group & EIF substance & Endp. & Eff. conc. & Obs. dur. & $\begin{array}{l}\text { Test } \\
\text { medium }\end{array}$ & Latin name & Phylum / division & Family & $\begin{array}{l}\text { Species } \\
\text { group }\end{array}$ \\
\hline PLONOR 2 & Methanol & EC50 & $<10000 \mathrm{ppm}$ & $96 \mathrm{~h}$ & sw & S. costatum & Bacillariophyta & Skeletonemaceae & alg \\
\hline
\end{tabular}




\section{Annex 3 Selected toxicity data (bacteria)}

Table 3.1

Effect concentrations as collected for the 'natural' substances and bacteria from the ECETOC EAT database as used in hazard calculations.

\begin{tabular}{|c|c|c|c|c|c|}
\hline EIF substance & Full name & CAS NO & Mol wt. & Durat. (h) & $\mathrm{EC50}(\mathrm{mg} / \mathrm{L})$ \\
\hline Benzene & Benzene & $71-43-2$ & 78.11 & 0.25 & 78.83 \\
\hline Xylene & Xylene & $1330-20-7$ & 106.18 & 0.25 & 8.55 \\
\hline $\mathrm{Cd}$ & Cadmium Chloride & $7440-43-9$ & 112.4 & 6 & 28.9 \\
\hline \multirow[t]{2}{*}{$\mathrm{Cr}$} & Potassium & $7778-50-9$ & 52 & 0.25 & 63.5 \\
\hline & Dichromate & & & & \\
\hline \multirow[t]{2}{*}{$\mathrm{Cr}$} & Potassium & $7778-50-9$ & 52 & 0.25 & 13.6 \\
\hline & Dichromate & & & & \\
\hline $\mathrm{Cu}$ & Copper II Sulphate & $7758-99-8$ & 63.55 & 0.25 & 0.95 \\
\hline $\mathrm{Pb}$ & Lead Nitrate & $10099-74-8$ & 207.2 & 0.25 & 0.14 \\
\hline \multirow[t]{2}{*}{$\mathrm{Hg}$} & Mercury II & $7487-94-7$ & 200.59 & 6 & 0.12 \\
\hline & Chloride & & & & \\
\hline Naphthalene & Naphthalene & $91-20-3$ & 128.18 & 1.25 & 1153.8 \\
\hline Organic acids & Acetic acid & $64-19-7$ & 60.05 & 0.08 & 9.42 \\
\hline Organic acids & Acetic acid & $64-19-7$ & 60.05 & 0.40 & 9.61 \\
\hline Organic acids & Butyric acid & $107-92-6$ & 88.11 & 0.08 & 16.92 \\
\hline Organic acids & Butyric acid & $107-92-6$ & 88.11 & 0.40 & 17.27 \\
\hline Organic acids & Formic acid & $64-18-6$ & 46.03 & 0.08 & 7.92 \\
\hline Organic acids & Formic acid & $64-18-6$ & 46.03 & 0.40 & 7.93 \\
\hline Phenol $\mathrm{CO}-\mathrm{C} 3$ & Phenol & $108-95-2$ & 94.11 & 0.25 & 17.60 \\
\hline Phenol $\mathrm{CO}-\mathrm{C} 3$ & Phenol & $108-95-2$ & 94.11 & 0.25 & 27.6 \\
\hline Phenol C0-C3 & Phenol & $108-95-2$ & 94.1 & 0.25 & 34.17 \\
\hline Methanol & Methanol & $67-56-1$ & 32.04 & 0.25 & 58230 \\
\hline Methanol & Methanol & $67-56-1$ & 32.04 & 0.25 & 29357.8 \\
\hline $\begin{array}{l}\text { Monoethylene } \\
\text { glycol }\end{array}$ & $\begin{array}{l}\text { Monoethylene } \\
\text { glycol }\end{array}$ & $107-21-1$ & 62.07 & 0.25 & 112364.8 \\
\hline $\mathrm{Zn}$ & Zinc Sulphate & $7446-20-0$ & 65.38 & 6 & 24.7 \\
\hline
\end{tabular}




\section{Annex 4 Norwegian implementation scheme for the RBA}

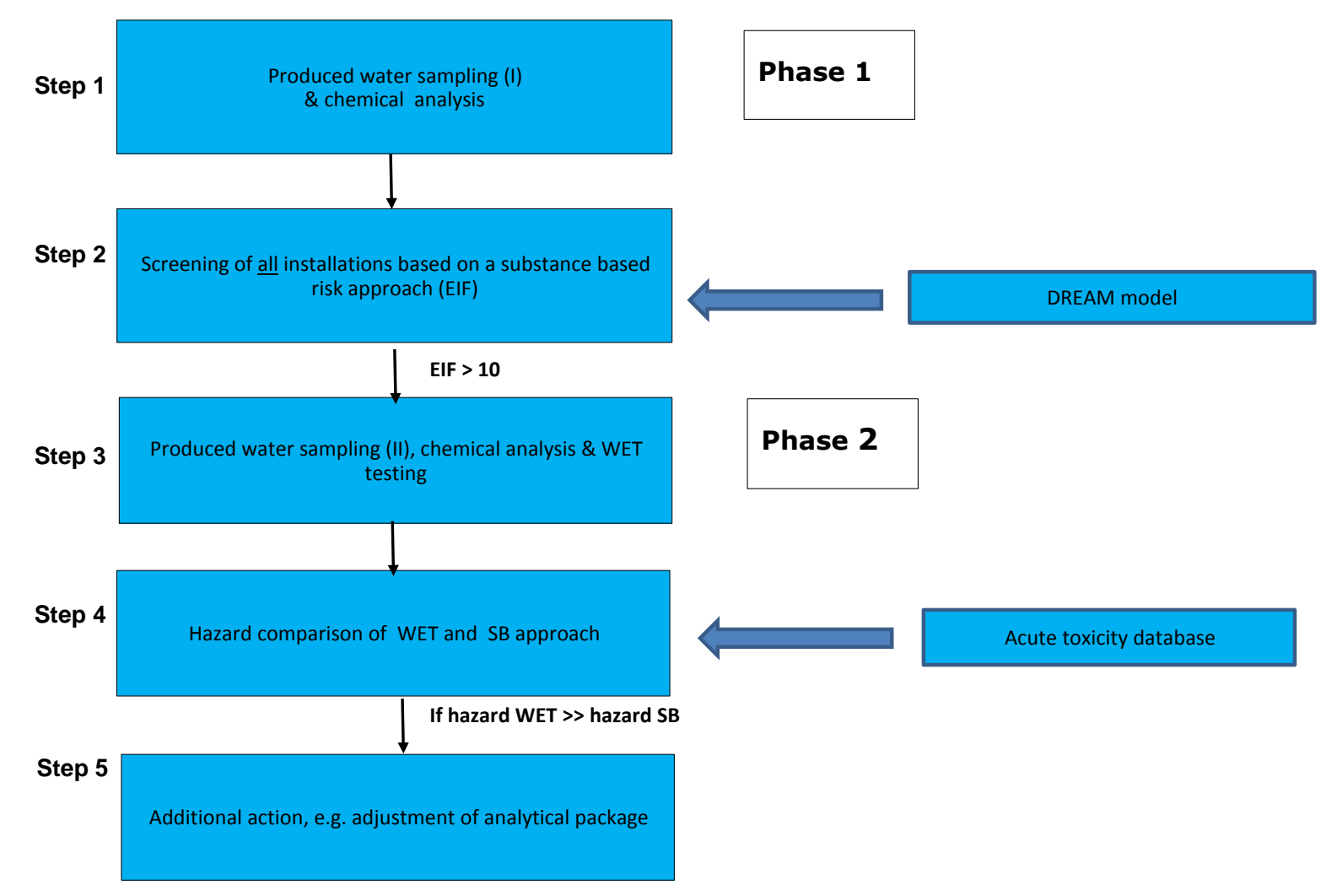




\section{Annex 5 Toxic Units as calculated with the Substance Based approach}

Toxic units (TU) are the discharged concentration divided by the $50 \%$ effect concentration (the geometric mean of all included test species: algae, crustacea and bacteria). The table below shows the TU for all platforms/discharges and substance groups as calculated and used in subsequent analyses. The TUs for most substance groups are identical among the different options, except for of course the production chemicals.

\section{Table 5.1}

Toxic units as calculated with the SB approach for each of the discharges and substance groups. Toxic units are listed foe each of the following options for including production chemicals: option 1, estimate based on day of sampling; option 2 estimate based on month of sampling; option 3 estimate based on year of sampling.

\begin{tabular}{|c|c|c|c|c|}
\hline Platform / Discharge & EIF group & Toxic Unit Option 1 & Toxic Unit Option 2 & Toxic Unit Option 3 \\
\hline Alvheim & BTEX & $4.43 \mathrm{E}-01$ & $4.43 \mathrm{E}-01$ & $4.43 \mathrm{E}-01$ \\
\hline Alvheim & Chromium & $8.50 \mathrm{E}-05$ & $8.50 \mathrm{E}-05$ & $8.50 \mathrm{E}-05$ \\
\hline Alvheim & Copper & $3.39 \mathrm{E}-02$ & $3.39 \mathrm{E}-02$ & $3.39 \mathrm{E}-02$ \\
\hline Alvheim & Lead & $1.02 \mathrm{E}-03$ & $1.02 \mathrm{E}-03$ & $1.02 \mathrm{E}-03$ \\
\hline Alvheim & Nickel & $2.84 \mathrm{E}-04$ & $2.84 \mathrm{E}-04$ & $2.84 \mathrm{E}-04$ \\
\hline Alvheim & Organic acid & $3.61 \mathrm{E}-01$ & $3.61 \mathrm{E}-01$ & $3.61 \mathrm{E}-01$ \\
\hline Alvheim & PAH 2-3 ring & $1.84 \mathrm{E}-01$ & $1.84 \mathrm{E}-01$ & $1.84 \mathrm{E}-01$ \\
\hline Alvheim & $\mathrm{PAH} 4+$ ring & $2.44 \mathrm{E}-04$ & $2.44 \mathrm{E}-04$ & $2.44 \mathrm{E}-04$ \\
\hline Alvheim & Phenol $\mathrm{CO}-\mathrm{C} 3$ & $8.70 \mathrm{E}-03$ & $8.70 \mathrm{E}-03$ & $8.70 \mathrm{E}-03$ \\
\hline Alvheim & Phenol C4-C5 & $1.22 \mathrm{E}-02$ & $1.22 \mathrm{E}-02$ & $1.22 \mathrm{E}-02$ \\
\hline Balder & Arsenic & $4.22 \mathrm{E}-03$ & $4.22 \mathrm{E}-03$ & $4.22 \mathrm{E}-03$ \\
\hline Balder & BTEX & $1.82 \mathrm{E}-01$ & $1.82 \mathrm{E}-01$ & $1.82 \mathrm{E}-01$ \\
\hline Balder & Cadmium & $8.93 \mathrm{E}-05$ & $8.93 \mathrm{E}-05$ & $8.93 \mathrm{E}-05$ \\
\hline Balder & Chromium & $1.34 \mathrm{E}-04$ & $1.34 \mathrm{E}-04$ & $1.34 \mathrm{E}-04$ \\
\hline Balder & Copper & $4.86 \mathrm{E}-02$ & $4.86 \mathrm{E}-02$ & $4.86 \mathrm{E}-02$ \\
\hline Balder & Lead & $2.36 \mathrm{E}-03$ & $2.36 \mathrm{E}-03$ & $2.36 \mathrm{E}-03$ \\
\hline Balder & Mercury & $4.93 E-04$ & $4.93 E-04$ & $4.93 E-04$ \\
\hline Balder & Naphthalenes & $1.04 \mathrm{E}-01$ & $1.04 \mathrm{E}-01$ & $1.04 \mathrm{E}-01$ \\
\hline Balder & Nickel & $8.96 \mathrm{E}-04$ & $8.96 \mathrm{E}-04$ & $8.96 \mathrm{E}-04$ \\
\hline Balder & Organic acid & $2.15 \mathrm{E}-01$ & $2.15 \mathrm{E}-01$ & $2.15 \mathrm{E}-01$ \\
\hline Balder & PAH 2-3 ring & $2.46 \mathrm{E}-01$ & $2.46 \mathrm{E}-01$ & $2.46 \mathrm{E}-01$ \\
\hline Balder & $\mathrm{PAH} 4+$ ring & $3.29 E-04$ & $3.29 \mathrm{E}-04$ & $3.29 E-04$ \\
\hline Brage & BTEX & $4.91 \mathrm{E}-01$ & $4.91 \mathrm{E}-01$ & $4.91 \mathrm{E}-01$ \\
\hline Brage & Cadmium & 8.93E-05 & 8.93E-05 & 8.93E-05 \\
\hline Brage & Chromium & $8.71 \mathrm{E}-05$ & $8.71 \mathrm{E}-05$ & $8.71 \mathrm{E}-05$ \\
\hline Brage & Copper & $1.82 \mathrm{E}-02$ & $1.82 \mathrm{E}-02$ & $1.82 \mathrm{E}-02$ \\
\hline Brage & Lead & $1.02 \mathrm{E}-03$ & $1.02 \mathrm{E}-03$ & $1.02 \mathrm{E}-03$ \\
\hline Brage & Mercury & $4.98 \mathrm{E}-04$ & $4.98 \mathrm{E}-04$ & $4.98 \mathrm{E}-04$ \\
\hline Brage & Naphthalenes & $5.87 \mathrm{E}-02$ & $5.87 \mathrm{E}-02$ & $5.87 \mathrm{E}-02$ \\
\hline Brage & Nickel & $2.84 \mathrm{E}-04$ & $2.84 \mathrm{E}-04$ & $2.84 \mathrm{E}-04$ \\
\hline Brage & Organic acid & $5.61 \mathrm{E}+00$ & $5.61 \mathrm{E}+00$ & $5.61 \mathrm{E}+00$ \\
\hline Brage & $\mathrm{PAH} 2-3$ ring & $1.26 \mathrm{E}-01$ & $1.26 \mathrm{E}-01$ & $1.26 \mathrm{E}-01$ \\
\hline Brage & $\mathrm{PAH} 4+$ ring & $1.62 \mathrm{E}-04$ & $1.62 \mathrm{E}-04$ & $1.62 \mathrm{E}-04$ \\
\hline Brage & Phenol $\mathrm{CO}-\mathrm{C} 3$ & $1.70 \mathrm{E}-01$ & $1.70 \mathrm{E}-01$ & $1.70 \mathrm{E}-01$ \\
\hline Brage & Phenol C4-C5 & $4.81 \mathrm{E}-02$ & $4.81 \mathrm{E}-02$ & $4.81 \mathrm{E}-02$ \\
\hline Brage & Phenol C6+ & $4.93 E-03$ & $4.93 \mathrm{E}-03$ & 4.93E-03 \\
\hline Brage & Prod. chems & $1.10 \mathrm{E}+00$ & $1.09 \mathrm{E}+00$ & $1.02 \mathrm{E}+00$ \\
\hline Brage & Zinc & 1.07E-03 & $1.07 \mathrm{E}-03$ & $1.07 \mathrm{E}-03$ \\
\hline Draugen & Aliphatic HCs & $3.41 \mathrm{E}+00$ & $3.41 \mathrm{E}+00$ & \\
\hline Draugen & Arsenic & $1.64 \mathrm{E}-03$ & $1.64 \mathrm{E}-03$ & \\
\hline
\end{tabular}




\begin{tabular}{|c|c|c|c|c|}
\hline Platform / Discharge & EIF group & Toxic Unit Option 1 & Toxic Unit Option 2 & Toxic Unit Option 3 \\
\hline Draugen & BTEX & $1.41 \mathrm{E}-01$ & $1.41 \mathrm{E}-01$ & \\
\hline Draugen & Cadmium & 8.93E-05 & 8.93E-05 & \\
\hline Draugen & Chromium & $3.21 \mathrm{E}-05$ & $3.21 \mathrm{E}-05$ & \\
\hline Draugen & Copper & $5.88 \mathrm{E}-03$ & $5.88 \mathrm{E}-03$ & \\
\hline Draugen & Lead & $1.02 \mathrm{E}-03$ & $1.02 \mathrm{E}-03$ & \\
\hline Draugen & Mercury & $4.93 E-04$ & $4.93 E-04$ & \\
\hline Draugen & Naphthalenes & 4.17E-02 & 4.17E-02 & \\
\hline Draugen & Nickel & $2.84 \mathrm{E}-04$ & $2.84 \mathrm{E}-04$ & \\
\hline Draugen & Organic acid & $2.47 E-01$ & $2.47 \mathrm{E}-01$ & \\
\hline Draugen & $\mathrm{PAH} 2-3$ ring & $1.12 \mathrm{E}-01$ & $1.12 \mathrm{E}-01$ & \\
\hline Draugen & $\mathrm{PAH} 4+$ ring & $1.81 \mathrm{E}-04$ & $1.81 \mathrm{E}-04$ & \\
\hline Draugen & Phenol C0-C3 & $5.51 \mathrm{E}-03$ & $5.51 \mathrm{E}-03$ & \\
\hline Draugen & Phenol C4-C5 & $1.45 \mathrm{E}-02$ & $1.45 \mathrm{E}-02$ & \\
\hline Draugen & Phenol C6+ & $5.56 \mathrm{E}-03$ & $5.56 \mathrm{E}-03$ & \\
\hline Draugen & Prod. chems & $5.64 \mathrm{E}-02$ & $1.09 \mathrm{E}-01$ & \\
\hline Draugen & Zinc & $1.07 E-03$ & $1.07 \mathrm{E}-03$ & \\
\hline Ekofisk J & Aliphatic HCs & $6.03 E-01$ & $6.03 E-01$ & $6.03 E-01$ \\
\hline Ekofisk J & Arsenic & 2.27E-03 & $2.27 \mathrm{E}-03$ & $2.27 \mathrm{E}-03$ \\
\hline Ekofisk J & BTEX & $7.26 \mathrm{E}-01$ & $7.26 \mathrm{E}-01$ & $7.26 \mathrm{E}-01$ \\
\hline Ekofisk J & Cadmium & 8.93E-05 & 8.93E-05 & 8.93E-05 \\
\hline Ekofisk J & Chromium & $1.55 \mathrm{E}-04$ & $1.55 \mathrm{E}-04$ & $1.55 \mathrm{E}-04$ \\
\hline Ekofisk J & Copper & $1.52 \mathrm{E}-03$ & $1.52 \mathrm{E}-03$ & $1.52 \mathrm{E}-03$ \\
\hline Ekofisk J & Lead & $1.02 \mathrm{E}-03$ & $1.02 \mathrm{E}-03$ & $1.02 \mathrm{E}-03$ \\
\hline Ekofisk J & Mercury & $8.23 E-04$ & $8.23 E-04$ & $8.23 E-04$ \\
\hline Ekofisk J & Naphthalenes & $1.67 \mathrm{E}-02$ & $1.67 \mathrm{E}-02$ & $1.67 \mathrm{E}-02$ \\
\hline Ekofisk J & Nickel & $3.78 \mathrm{E}-04$ & $3.78 \mathrm{E}-04$ & $3.78 \mathrm{E}-04$ \\
\hline Ekofisk J & Organic acid & $2.90 \mathrm{E}+00$ & $2.90 \mathrm{E}+00$ & $2.90 \mathrm{E}+00$ \\
\hline Ekofisk J & PAH 2-3 ring & $3.58 \mathrm{E}-02$ & $3.58 \mathrm{E}-02$ & $3.58 \mathrm{E}-02$ \\
\hline Ekofisk J & $\mathrm{PAH} 4+$ ring & $6.08 \mathrm{E}-05$ & $6.08 \mathrm{E}-05$ & $6.08 \mathrm{E}-05$ \\
\hline Ekofisk J & Phenol C0-C3 & $1.33 \mathrm{E}-01$ & $1.33 \mathrm{E}-01$ & $1.33 \mathrm{E}-01$ \\
\hline Ekofisk J & Phenol C4-C5 & $2.83 \mathrm{E}-03$ & $2.83 \mathrm{E}-03$ & $2.83 \mathrm{E}-03$ \\
\hline Ekofisk J & Phenol C6+ & $1.33 \mathrm{E}-03$ & $1.33 \mathrm{E}-03$ & $1.33 \mathrm{E}-03$ \\
\hline Ekofisk J & Prod. chems & $1.02 \mathrm{E}+00$ & $1.12 \mathrm{E}+00$ & $3.34 \mathrm{E}+00$ \\
\hline Ekofisk J & Zinc & 1.07E-03 & 1.07E-03 & 1.07E-03 \\
\hline Ekofisk M & Aliphatic HCs & $2.77 \mathrm{E}+00$ & $2.77 \mathrm{E}+00$ & $2.77 \mathrm{E}+00$ \\
\hline Ekofisk M & Arsenic & 2.07E-03 & 2.07E-03 & 2.07E-03 \\
\hline Ekofisk M & BTEX & $5.65 \mathrm{E}-01$ & $5.65 \mathrm{E}-01$ & $5.65 \mathrm{E}-01$ \\
\hline Ekofisk M & Cadmium & 8.93E-05 & 8.93E-05 & 8.93E-05 \\
\hline Ekofisk M & Chromium & $3.85 E-04$ & $3.85 E-04$ & $3.85 E-04$ \\
\hline Ekofisk M & Copper & $2.95 \mathrm{E}-03$ & $2.95 \mathrm{E}-03$ & $2.95 \mathrm{E}-03$ \\
\hline Ekofisk M & Lead & $1.02 \mathrm{E}-03$ & $1.02 \mathrm{E}-03$ & $1.02 \mathrm{E}-03$ \\
\hline Ekofisk M & Mercury & $4.93 E-04$ & 4.93E-04 & 4.93E-04 \\
\hline Ekofisk M & Naphthalenes & 7.50E-02 & 7.50E-02 & 7.50E-02 \\
\hline Ekofisk M & Nickel & $1.32 \mathrm{E}-03$ & $1.32 \mathrm{E}-03$ & $1.32 \mathrm{E}-03$ \\
\hline Ekofisk M & Organic acid & $3.66 \mathrm{E}+00$ & $3.66 \mathrm{E}+00$ & $3.66 \mathrm{E}+00$ \\
\hline Ekofisk M & PAH 2-3 ring & $1.51 \mathrm{E}-01$ & $1.51 \mathrm{E}-01$ & $1.51 \mathrm{E}-01$ \\
\hline Ekofisk M & $\mathrm{PAH} 4+$ ring & $2.35 \mathrm{E}-04$ & $2.35 \mathrm{E}-04$ & $2.35 \mathrm{E}-04$ \\
\hline Ekofisk M & Phenol C0-C3 & $1.50 \mathrm{E}-01$ & $1.50 \mathrm{E}-01$ & $1.50 \mathrm{E}-01$ \\
\hline Ekofisk M & Phenol C4-C5 & $5.19 E-03$ & $5.19 \mathrm{E}-03$ & $5.19 \mathrm{E}-03$ \\
\hline Ekofisk M & Phenol C6+ & $3.47 \mathrm{E}-03$ & 3.47E-03 & $3.47 \mathrm{E}-03$ \\
\hline Ekofisk M & Prod. chems & $1.12 \mathrm{E}+00$ & $1.03 E+00$ & $1.23 \mathrm{E}+00$ \\
\hline Ekofisk M & Zinc & $1.07 E-03$ & $1.07 E-03$ & $1.07 E-03$ \\
\hline Grane & Aliphatic HCs & $1.56 \mathrm{E}+00$ & $1.56 \mathrm{E}+00$ & $1.56 \mathrm{E}+00$ \\
\hline Grane & Arsenic & $2.81 \mathrm{E}-04$ & $2.81 \mathrm{E}-04$ & $2.81 \mathrm{E}-04$ \\
\hline Grane & BTEX & $1.52 \mathrm{E}-01$ & $1.52 \mathrm{E}-01$ & $1.52 \mathrm{E}-01$ \\
\hline Grane & Cadmium & $7.14 \mathrm{E}-05$ & $7.14 \mathrm{E}-05$ & $7.14 \mathrm{E}-05$ \\
\hline Grane & Chromium & $3.21 \mathrm{E}-05$ & $3.21 \mathrm{E}-05$ & $3.21 \mathrm{E}-05$ \\
\hline Grane & Copper & $2.32 \mathrm{E}-03$ & $2.32 \mathrm{E}-03$ & $2.32 \mathrm{E}-03$ \\
\hline Grane & Lead & 7.37E-04 & 7.37E-04 & 7.37E-04 \\
\hline Grane & Mercury & $6.71 \mathrm{E}-05$ & $6.71 \mathrm{E}-05$ & $6.71 \mathrm{E}-05$ \\
\hline Grane & Naphthalenes & $6.89 \mathrm{E}-02$ & $6.89 \mathrm{E}-02$ & 6.89E-02 \\
\hline Grane & Nickel & $1.12 \mathrm{E}-04$ & $1.12 \mathrm{E}-04$ & $1.12 \mathrm{E}-04$ \\
\hline Grane & Organic acid & $1.42 \mathrm{E}+00$ & $1.42 \mathrm{E}+00$ & $1.42 \mathrm{E}+00$ \\
\hline Grane & PAH 2-3 ring & $1.42 \mathrm{E}-01$ & $1.42 \mathrm{E}-01$ & $1.42 \mathrm{E}-01$ \\
\hline Grane & $\mathrm{PAH} 4+$ ring & $2.57 E-04$ & $2.57 \mathrm{E}-04$ & $2.57 \mathrm{E}-04$ \\
\hline Grane & Phenol C0-C3 & $1.15 \mathrm{E}-02$ & $1.15 \mathrm{E}-02$ & $1.15 \mathrm{E}-02$ \\
\hline Grane & Phenol C4-C5 & $6.81 \mathrm{E}-03$ & $6.81 \mathrm{E}-03$ & $6.81 \mathrm{E}-03$ \\
\hline Grane & Phenol C6+ & $4.92 \mathrm{E}-03$ & $4.92 \mathrm{E}-03$ & $4.92 \mathrm{E}-03$ \\
\hline Grane & Prod. chems & $6.53 \mathrm{E}-01$ & $1.21 \mathrm{E}+00$ & $1.18 \mathrm{E}+00$ \\
\hline Grane & Zinc & $9.44 \mathrm{E}-04$ & $9.44 \mathrm{E}-04$ & $9.44 \mathrm{E}-04$ \\
\hline Gullfaks A & Aliphatic HCs & $1.94 \mathrm{E}+00$ & $1.94 \mathrm{E}+00$ & $1.94 \mathrm{E}+00$ \\
\hline Gullfaks A & Arsenic & $5.59 \mathrm{E}-04$ & $5.59 \mathrm{E}-04$ & $5.59 \mathrm{E}-04$ \\
\hline Gullfaks A & BTEX & $8.82 \mathrm{E}-01$ & $8.82 \mathrm{E}-01$ & $8.82 \mathrm{E}-01$ \\
\hline Gullfaks A & Cadmium & $5.95 E-06$ & $5.95 \mathrm{E}-06$ & $5.95 E-06$ \\
\hline Gullfaks A & Chromium & $2.83 E-04$ & $2.83 \mathrm{E}-04$ & $2.83 E-04$ \\
\hline Gullfaks A & Copper & $1.24 \mathrm{E}-03$ & $1.24 \mathrm{E}-03$ & $1.24 \mathrm{E}-03$ \\
\hline Gullfaks A & Lead & $1.20 \mathrm{E}-03$ & $1.20 \mathrm{E}-03$ & $1.20 \mathrm{E}-03$ \\
\hline Gullfaks A & Mercury & $1.69 \mathrm{E}-03$ & $1.69 \mathrm{E}-03$ & $1.69 \mathrm{E}-03$ \\
\hline Gullfaks A & Naphthalenes & $2.57 \mathrm{E}-02$ & $2.57 \mathrm{E}-02$ & $2.57 \mathrm{E}-02$ \\
\hline Gullfaks A & Nickel & $2.30 \mathrm{E}-04$ & $2.30 \mathrm{E}-04$ & $2.30 \mathrm{E}-04$ \\
\hline Gullfaks A & Organic acid & $6.84 \mathrm{E}-01$ & $6.84 \mathrm{E}-01$ & $6.84 \mathrm{E}-01$ \\
\hline Gullfaks A & $\mathrm{PAH} 2-3$ ring & $4.27 \mathrm{E}-02$ & $4.27 \mathrm{E}-02$ & $4.27 \mathrm{E}-02$ \\
\hline
\end{tabular}




\begin{tabular}{|c|c|c|c|c|}
\hline Platform / Discharge & EIF group & Toxic Unit Option 1 & Toxic Unit Option 2 & Toxic Unit Option 3 \\
\hline Gullfaks A & $\mathrm{PAH} 4+$ ring & $7.85 E-05$ & 7.85E-05 & $7.85 E-05$ \\
\hline Gullfaks A & Phenol C0-C3 & $2.49 \mathrm{E}-01$ & $2.49 \mathrm{E}-01$ & $2.49 \mathrm{E}-01$ \\
\hline Gullfaks A & Phenol C4-C5 & $2.04 \mathrm{E}-02$ & $2.04 \mathrm{E}-02$ & $2.04 \mathrm{E}-02$ \\
\hline Gullfaks A & Phenol C6+ & $2.26 \mathrm{E}-03$ & $2.26 \mathrm{E}-03$ & $2.26 \mathrm{E}-03$ \\
\hline Gullfaks A & Prod. chems & $2.99 E+01$ & $5.61 \mathrm{E}+01$ & $4.00 E+01$ \\
\hline Gullfaks A & Zinc & $7.46 \mathrm{E}-03$ & 7.46E-03 & $7.46 \mathrm{E}-03$ \\
\hline Gullfaks B & Aliphatic HCs & $8.51 \mathrm{E}-01$ & $8.51 \mathrm{E}-01$ & $8.51 \mathrm{E}-01$ \\
\hline Gullfaks B & Arsenic & $1.05 \mathrm{E}-04$ & $1.05 \mathrm{E}-04$ & $1.05 \mathrm{E}-04$ \\
\hline Gullfaks B & BTEX & $4.24 \mathrm{E}-01$ & $4.24 \mathrm{E}-01$ & $4.24 \mathrm{E}-01$ \\
\hline Gullfaks B & Cadmium & $5.95 \mathrm{E}-06$ & 5.95E-06 & 5.95E-06 \\
\hline Gullfaks B & Chromium & $1.68 \mathrm{E}-04$ & $1.68 \mathrm{E}-04$ & $1.68 \mathrm{E}-04$ \\
\hline Gullfaks B & Copper & $1.26 \mathrm{E}-03$ & $1.26 \mathrm{E}-03$ & $1.26 \mathrm{E}-03$ \\
\hline Gullfaks B & Lead & $9.00 \mathrm{E}-04$ & $9.00 \mathrm{E}-04$ & $9.00 \mathrm{E}-04$ \\
\hline Gullfaks B & Mercury & $9.12 \mathrm{E}-05$ & $9.12 \mathrm{E}-05$ & $9.12 \mathrm{E}-05$ \\
\hline Gullfaks B & Naphthalenes & $5.00 \mathrm{E}-02$ & $5.00 \mathrm{E}-02$ & $5.00 \mathrm{E}-02$ \\
\hline Gullfaks B & Nickel & 3.07E-04 & 3.07E-04 & 3.07E-04 \\
\hline Gullfaks B & Organic acid & $2.79 \mathrm{E}-01$ & $2.79 \mathrm{E}-01$ & $2.79 \mathrm{E}-01$ \\
\hline Gullfaks B & $\mathrm{PAH} 2-3$ ring & $5.86 \mathrm{E}-02$ & $5.86 \mathrm{E}-02$ & $5.86 \mathrm{E}-02$ \\
\hline Gullfaks B & $\mathrm{PAH} 4+$ ring & $1.11 \mathrm{E}-04$ & $1.11 \mathrm{E}-04$ & $1.11 \mathrm{E}-04$ \\
\hline Gullfaks B & Phenol $\mathrm{CO}-\mathrm{C} 3$ & $2.11 \mathrm{E}-02$ & $2.11 \mathrm{E}-02$ & $2.11 \mathrm{E}-02$ \\
\hline Gullfaks B & Phenol C4-C5 & $1.05 \mathrm{E}-02$ & $1.05 \mathrm{E}-02$ & $1.05 \mathrm{E}-02$ \\
\hline Gullfaks B & Phenol C6+ & $3.55 \mathrm{E}-03$ & $3.55 \mathrm{E}-03$ & $3.55 \mathrm{E}-03$ \\
\hline Gullfaks B & Prod. chems & $5.02 E+00$ & $3.97 E+00$ & $6.02 E+00$ \\
\hline Gullfaks B & Zinc & $2.87 \mathrm{E}-03$ & $2.87 \mathrm{E}-03$ & $2.87 \mathrm{E}-03$ \\
\hline Gullfaks C & Aliphatic HCs & $3.26 \mathrm{E}+00$ & $3.26 \mathrm{E}+00$ & $3.26 \mathrm{E}+00$ \\
\hline Gullfaks C & Arsenic & $1.87 \mathrm{E}-04$ & $1.87 \mathrm{E}-04$ & $1.87 \mathrm{E}-04$ \\
\hline Gullfaks C & BTEX & $1.02 E+00$ & $1.02 \mathrm{E}+00$ & $1.02 E+00$ \\
\hline Gullfaks C & Cadmium & $8.34 \mathrm{E}-06$ & $8.34 \mathrm{E}-06$ & $8.34 \mathrm{E}-06$ \\
\hline Gullfaks C & Chromium & $2.89 \mathrm{E}-04$ & $2.89 \mathrm{E}-04$ & $2.89 \mathrm{E}-04$ \\
\hline Gullfaks C & Copper & $1.19 \mathrm{E}-03$ & $1.19 \mathrm{E}-03$ & $1.19 \mathrm{E}-03$ \\
\hline Gullfaks C & Lead & $1.47 \mathrm{E}-03$ & 1.47E-03 & $1.47 \mathrm{E}-03$ \\
\hline Gullfaks C & Mercury & $1.03 \mathrm{E}-04$ & $1.03 E-04$ & $1.03 \mathrm{E}-04$ \\
\hline Gullfaks C & Naphthalenes & $4.02 \mathrm{E}-02$ & $4.02 \mathrm{E}-02$ & $4.02 \mathrm{E}-02$ \\
\hline Gullfaks C & Nickel & $2.84 \mathrm{E}-04$ & $2.84 \mathrm{E}-04$ & $2.84 \mathrm{E}-04$ \\
\hline Gullfaks C & Organic acid & $3.77 E+00$ & $3.77 E+00$ & $3.77 E+00$ \\
\hline Gullfaks C & $\mathrm{PAH} 2-3$ ring & $1.85 \mathrm{E}-01$ & $1.85 \mathrm{E}-01$ & $1.85 \mathrm{E}-01$ \\
\hline Gullfaks C & $\mathrm{PAH} 4+$ ring & $5.45 \mathrm{E}-04$ & $5.45 E-04$ & $5.45 \mathrm{E}-04$ \\
\hline Gullfaks C & Phenol $\mathrm{CO}-\mathrm{C} 3$ & $1.02 \mathrm{E}-01$ & $1.02 \mathrm{E}-01$ & $1.02 \mathrm{E}-01$ \\
\hline Gullfaks C & Phenol C4-C5 & $1.67 \mathrm{E}-02$ & $1.67 \mathrm{E}-02$ & $1.67 \mathrm{E}-02$ \\
\hline Gullfaks C & Phenol C6+ & $5.01 \mathrm{E}-03$ & $5.01 \mathrm{E}-03$ & $5.01 \mathrm{E}-03$ \\
\hline Gullfaks C & Prod. chems & $4.48 \mathrm{E}+00$ & $4.12 E+01$ & $2.46 \mathrm{E}+01$ \\
\hline Gullfaks C & Zinc & $9.63 \mathrm{E}-04$ & $9.63 \mathrm{E}-04$ & $9.63 \mathrm{E}-04$ \\
\hline Heidrun & Aliphatic HCs & $7.87 E+00$ & $7.87 E+00$ & $7.87 E+00$ \\
\hline Heidrun & Arsenic & $2.62 \mathrm{E}-04$ & $2.62 \mathrm{E}-04$ & $2.62 \mathrm{E}-04$ \\
\hline Heidrun & BTEX & $1.69 \mathrm{E}-01$ & $1.69 \mathrm{E}-01$ & $1.69 \mathrm{E}-01$ \\
\hline Heidrun & Cadmium & $9.92 \mathrm{E}-06$ & $9.92 \mathrm{E}-06$ & $9.92 \mathrm{E}-06$ \\
\hline Heidrun & Chromium & $1.76 \mathrm{E}-03$ & $1.76 \mathrm{E}-03$ & $1.76 \mathrm{E}-03$ \\
\hline Heidrun & Copper & $4.52 \mathrm{E}-03$ & $4.52 \mathrm{E}-03$ & $4.52 \mathrm{E}-03$ \\
\hline Heidrun & Lead & $3.46 \mathrm{E}-03$ & $3.46 \mathrm{E}-03$ & $3.46 \mathrm{E}-03$ \\
\hline Heidrun & Mercury & $2.75 \mathrm{E}-04$ & $2.75 \mathrm{E}-04$ & $2.75 \mathrm{E}-04$ \\
\hline Heidrun & Naphthalenes & $5.69 \mathrm{E}-02$ & $5.69 \mathrm{E}-02$ & $5.69 \mathrm{E}-02$ \\
\hline Heidrun & Nickel & $2.06 \mathrm{E}-03$ & $2.06 \mathrm{E}-03$ & $2.06 \mathrm{E}-03$ \\
\hline Heidrun & Organic acid & $2.74 \mathrm{E}+00$ & $2.74 \mathrm{E}+00$ & $2.74 \mathrm{E}+00$ \\
\hline Heidrun & $\mathrm{PAH} 2-3$ ring & $3.96 \mathrm{E}-01$ & $3.96 \mathrm{E}-01$ & $3.96 \mathrm{E}-01$ \\
\hline Heidrun & $\mathrm{PAH} 4+$ ring & $1.07 \mathrm{E}-03$ & $1.07 \mathrm{E}-03$ & $1.07 \mathrm{E}-03$ \\
\hline Heidrun & Phenol $\mathrm{CO}-\mathrm{C} 3$ & $6.44 \mathrm{E}-02$ & $6.44 \mathrm{E}-02$ & $6.44 \mathrm{E}-02$ \\
\hline Heidrun & Phenol C4-C5 & $1.56 \mathrm{E}-02$ & $1.56 \mathrm{E}-02$ & $1.56 \mathrm{E}-02$ \\
\hline Heidrun & Phenol C6+ & $1.95 \mathrm{E}-02$ & $1.95 \mathrm{E}-02$ & $1.95 \mathrm{E}-02$ \\
\hline Heidrun & Prod. chems & $2.66 \mathrm{E}+00$ & $1.79 \mathrm{E}+00$ & $2.86 \mathrm{E}+00$ \\
\hline Heidrun & Zinc & $2.52 \mathrm{E}-03$ & $2.52 \mathrm{E}-03$ & $2.52 \mathrm{E}-03$ \\
\hline Jotun & Aliphatic HCs & $1.02 \mathrm{E}+01$ & $1.02 \mathrm{E}+01$ & $1.02 \mathrm{E}+01$ \\
\hline Jotun & Arsenic & 3.44E-03 & 3.44E-03 & $3.44 \mathrm{E}-03$ \\
\hline Jotun & BTEX & $3.90 \mathrm{E}-01$ & $3.90 \mathrm{E}-01$ & $3.90 \mathrm{E}-01$ \\
\hline Jotun & Cadmium & $1.49 \mathrm{E}-04$ & $1.49 \mathrm{E}-04$ & $1.49 \mathrm{E}-04$ \\
\hline Jotun & Chromium & $1.76 \mathrm{E}-04$ & $1.76 \mathrm{E}-04$ & $1.76 \mathrm{E}-04$ \\
\hline Jotun & Copper & $6.56 \mathrm{E}-02$ & $6.56 \mathrm{E}-02$ & $6.56 \mathrm{E}-02$ \\
\hline Jotun & Lead & $1.27 \mathrm{E}-03$ & $1.27 \mathrm{E}-03$ & $1.27 \mathrm{E}-03$ \\
\hline Jotun & Mercury & $5.09 \mathrm{E}-04$ & $5.09 E-04$ & $5.09 E-04$ \\
\hline Jotun & Naphthalenes & $1.08 \mathrm{E}-01$ & $1.08 \mathrm{E}-01$ & $1.08 \mathrm{E}-01$ \\
\hline Jotun & Nickel & $2.84 \mathrm{E}-04$ & $2.84 \mathrm{E}-04$ & $2.84 \mathrm{E}-04$ \\
\hline Jotun & Organic acid & $5.25 E+00$ & $5.25 \mathrm{E}+00$ & $5.25 \mathrm{E}+00$ \\
\hline Jotun & $\mathrm{PAH} 2-3$ ring & $4.22 \mathrm{E}-01$ & $4.22 \mathrm{E}-01$ & $4.22 \mathrm{E}-01$ \\
\hline Jotun & $\mathrm{PAH} 4+$ ring & $6.68 \mathrm{E}-04$ & $6.68 \mathrm{E}-04$ & $6.68 \mathrm{E}-04$ \\
\hline Jotun & Phenol $\mathrm{CO}-\mathrm{C} 3$ & $8.55 \mathrm{E}-02$ & $8.55 \mathrm{E}-02$ & $8.55 \mathrm{E}-02$ \\
\hline Jotun & Phenol C4-C5 & $2.31 \mathrm{E}-02$ & $2.31 \mathrm{E}-02$ & $2.31 \mathrm{E}-02$ \\
\hline Jotun & Phenol C6+ & $9.93 \mathrm{E}-03$ & $9.93 \mathrm{E}-03$ & $9.93 \mathrm{E}-03$ \\
\hline Jotun & Prod. chems & $8.58 E+00$ & $3.44 \mathrm{E}+00$ & $3.96 \mathrm{E}+00$ \\
\hline Jotun & Zinc & 1.07E-03 & $1.07 \mathrm{E}-03$ & 1.07E-03 \\
\hline Knarr & Aliphatic HCs & $3.90 E+01$ & $3.90 E+01$ & $3.90 E+01$ \\
\hline Knarr & Arsenic & $2.27 \mathrm{E}-03$ & $2.27 \mathrm{E}-03$ & $2.27 \mathrm{E}-03$ \\
\hline Knarr & BTEX & $7.71 \mathrm{E}-01$ & $7.71 \mathrm{E}-01$ & $7.71 \mathrm{E}-01$ \\
\hline Knarr & Cadmium & $8.93 E-05$ & 8.93E-05 & 8.93E-05 \\
\hline
\end{tabular}




\begin{tabular}{|c|c|c|c|c|}
\hline Platform / Discharge & EIF group & Toxic Unit Option 1 & Toxic Unit Option 2 & Toxic Unit Option 3 \\
\hline Knarr & Chromium & $4.87 E-04$ & $4.87 \mathrm{E}-04$ & $4.87 E-04$ \\
\hline Knarr & Copper & $5.20 \mathrm{E}-02$ & $5.20 \mathrm{E}-02$ & $5.20 \mathrm{E}-02$ \\
\hline Knarr & Lead & $1.02 \mathrm{E}-03$ & $1.02 \mathrm{E}-03$ & $1.02 \mathrm{E}-03$ \\
\hline Knarr & Mercury & $3.49 \mathrm{E}-03$ & $3.49 \mathrm{E}-03$ & $3.49 \mathrm{E}-03$ \\
\hline Knarr & Naphthalenes & $1.81 \mathrm{E}-01$ & $1.81 \mathrm{E}-01$ & $1.81 \mathrm{E}-01$ \\
\hline Knarr & Nickel & $1.92 \mathrm{E}-03$ & $1.92 \mathrm{E}-03$ & $1.92 \mathrm{E}-03$ \\
\hline Knarr & Organic acid & $3.81 \mathrm{E}+00$ & $3.81 E+00$ & $3.81 \mathrm{E}+00$ \\
\hline Knarr & PAH 2-3 ring & $6.86 \mathrm{E}-01$ & $6.86 \mathrm{E}-01$ & $6.86 \mathrm{E}-01$ \\
\hline Knarr & $\mathrm{PAH} 4+$ ring & $1.46 \mathrm{E}-03$ & $1.46 \mathrm{E}-03$ & $1.46 \mathrm{E}-03$ \\
\hline Knarr & Phenol $\mathrm{CO}-\mathrm{C} 3$ & $1.59 \mathrm{E}-01$ & $1.59 \mathrm{E}-01$ & $1.59 \mathrm{E}-01$ \\
\hline Knarr & Phenol C4-C5 & $5.65 E-02$ & $5.65 \mathrm{E}-02$ & $5.65 E-02$ \\
\hline Knarr & Phenol C6+ & 9.47E-03 & 9.47E-03 & 9.47E-03 \\
\hline Knarr & Prod. chems & $1.66 \mathrm{E}+01$ & $2.13 E+01$ & $1.43 \mathrm{E}+02$ \\
\hline Knarr & Zinc & $1.07 \mathrm{E}-03$ & $1.07 E-03$ & $1.07 \mathrm{E}-03$ \\
\hline Norne & Aliphatic HCs & $1.77 \mathrm{E}+00$ & $1.77 \mathrm{E}+00$ & $1.77 \mathrm{E}+00$ \\
\hline Norne & Arsenic & $1.76 \mathrm{E}-04$ & $1.76 \mathrm{E}-04$ & $1.76 \mathrm{E}-04$ \\
\hline Norne & BTEX & $1.04 \mathrm{E}+00$ & $1.04 \mathrm{E}+00$ & $1.04 \mathrm{E}+00$ \\
\hline Norne & Cadmium & $1.43 \mathrm{E}-05$ & $1.43 \mathrm{E}-05$ & $1.43 \mathrm{E}-05$ \\
\hline Norne & Chromium & $4.01 \mathrm{E}-04$ & $4.01 \mathrm{E}-04$ & $4.01 \mathrm{E}-04$ \\
\hline Norne & Copper & $1.12 \mathrm{E}-03$ & $1.12 \mathrm{E}-03$ & $1.12 \mathrm{E}-03$ \\
\hline Norne & Lead & 3.77E-04 & 3.77E-04 & 3.77E-04 \\
\hline Norne & Mercury & $7.86 \mathrm{E}-04$ & $7.86 \mathrm{E}-04$ & $7.86 \mathrm{E}-04$ \\
\hline Norne & Naphthalenes & $3.96 \mathrm{E}-02$ & $3.96 \mathrm{E}-02$ & $3.96 \mathrm{E}-02$ \\
\hline Norne & Nickel & 1.17E-03 & 1.17E-03 & 1.17E-03 \\
\hline Norne & Organic acid & $4.16 \mathrm{E}+00$ & $4.16 \mathrm{E}+00$ & $4.16 \mathrm{E}+00$ \\
\hline Norne & PAH 2-3 ring & $1.10 \mathrm{E}-01$ & $1.10 \mathrm{E}-01$ & $1.10 \mathrm{E}-01$ \\
\hline Norne & $\mathrm{PAH} 4+$ ring & $1.43 \mathrm{E}-04$ & $1.43 \mathrm{E}-04$ & $1.43 \mathrm{E}-04$ \\
\hline Norne & Phenol $\mathrm{C} 0-\mathrm{C} 3$ & $1.92 \mathrm{E}-01$ & $1.92 \mathrm{E}-01$ & $1.92 \mathrm{E}-01$ \\
\hline Norne & Phenol C4-C5 & $3.12 \mathrm{E}-02$ & $3.12 \mathrm{E}-02$ & $3.12 \mathrm{E}-02$ \\
\hline Norne & Phenol C6+ & 4.24E-03 & $4.24 \mathrm{E}-03$ & $4.24 \mathrm{E}-03$ \\
\hline Norne & Prod. chems & $2.01 \mathrm{E}+00$ & $8.31 E+00$ & $6.36 \mathrm{E}+00$ \\
\hline Norne & Zinc & $8.56 \mathrm{E}-04$ & $8.56 \mathrm{E}-04$ & $8.56 \mathrm{E}-04$ \\
\hline Skarv & Aliphatic HCs & $1.49 \mathrm{E}+00$ & $1.49 \mathrm{E}+00$ & $1.49 \mathrm{E}+00$ \\
\hline Skarv & Arsenic & $5.86 \mathrm{E}-04$ & $5.86 \mathrm{E}-04$ & $5.86 \mathrm{E}-04$ \\
\hline Skarv & BTEX & $1.57 \mathrm{E}+00$ & $1.57 \mathrm{E}+00$ & $1.57 \mathrm{E}+00$ \\
\hline Skarv & Cadmium & $8.93 E-05$ & 8.93E-05 & $8.93 E-05$ \\
\hline Skarv & Chromium & $8.34 \mathrm{E}-05$ & $8.34 \mathrm{E}-05$ & $8.34 \mathrm{E}-05$ \\
\hline Skarv & Copper & 2.92E-02 & $2.92 \mathrm{E}-02$ & $2.92 \mathrm{E}-02$ \\
\hline Skarv & Lead & $3.27 E-03$ & 3.27E-03 & 3.27E-03 \\
\hline Skarv & Mercury & $1.42 \mathrm{E}-05$ & $1.42 \mathrm{E}-05$ & $1.42 \mathrm{E}-05$ \\
\hline Skarv & Naphthalenes & $5.45 \mathrm{E}-02$ & $5.45 \mathrm{E}-02$ & $5.45 \mathrm{E}-02$ \\
\hline Skarv & Nickel & $9.46 \mathrm{E}-04$ & $9.46 \mathrm{E}-04$ & $9.46 \mathrm{E}-04$ \\
\hline Skarv & Organic acid & $2.57 E+00$ & $2.57 E+00$ & $2.57 \mathrm{E}+00$ \\
\hline Skarv & PAH 2-3 ring & $6.10 \mathrm{E}-02$ & $6.10 \mathrm{E}-02$ & $6.10 \mathrm{E}-02$ \\
\hline Skarv & $\mathrm{PAH} 4+$ ring & $6.64 \mathrm{E}-05$ & $6.64 \mathrm{E}-05$ & $6.64 \mathrm{E}-05$ \\
\hline Skarv & Phenol C0-C3 & $1.05 \mathrm{E}+00$ & $1.05 E+00$ & $1.05 \mathrm{E}+00$ \\
\hline Skarv & Phenol C4-C5 & $5.33 \mathrm{E}-02$ & 5.33E-02 & $5.33 \mathrm{E}-02$ \\
\hline Skarv & Phenol C6+ & $5.37 \mathrm{E}-03$ & $5.37 \mathrm{E}-03$ & $5.37 \mathrm{E}-03$ \\
\hline Skarv & Prod. chems & $5.12 \mathrm{E}-02$ & $5.68 \mathrm{E}+01$ & $5.39 \mathrm{E}+01$ \\
\hline Skarv & Zinc & $4.12 \mathrm{E}-03$ & $4.12 \mathrm{E}-03$ & $4.12 \mathrm{E}-03$ \\
\hline Snorre A & Aliphatic HCs & $6.81 \mathrm{E}-01$ & $6.81 \mathrm{E}-01$ & $6.81 E-01$ \\
\hline Snorre A & Arsenic & 2.77E-02 & 2.77E-02 & 2.77E-02 \\
\hline Snorre A & BTEX & $4.85 \mathrm{E}-01$ & $4.85 \mathrm{E}-01$ & $4.85 \mathrm{E}-01$ \\
\hline Snorre A & Cadmium & $2.18 \mathrm{E}-05$ & $2.18 \mathrm{E}-05$ & $2.18 \mathrm{E}-05$ \\
\hline Snorre A & Chromium & 4.65E-05 & $4.65 \mathrm{E}-05$ & 4.65E-05 \\
\hline Snorre A & Copper & $2.58 \mathrm{E}-03$ & $2.58 \mathrm{E}-03$ & $2.58 \mathrm{E}-03$ \\
\hline Snorre A & Lead & $4.09 E-04$ & $4.09 E-04$ & $4.09 \mathrm{E}-04$ \\
\hline Snorre A & Mercury & $2.62 \mathrm{E}-04$ & $2.62 \mathrm{E}-04$ & $2.62 E-04$ \\
\hline Snorre A & Naphthalenes & $3.84 \mathrm{E}-02$ & $3.84 \mathrm{E}-02$ & $3.84 \mathrm{E}-02$ \\
\hline Snorre A & Nickel & $3.32 \mathrm{E}-05$ & $3.32 \mathrm{E}-05$ & $3.32 \mathrm{E}-05$ \\
\hline Snorre A & Organic acid & $2.23 \mathrm{E}+00$ & $2.23 E+00$ & $2.23 \mathrm{E}+00$ \\
\hline Snorre A & PAH 2-3 ring & $3.96 \mathrm{E}-02$ & $3.96 \mathrm{E}-02$ & $3.96 \mathrm{E}-02$ \\
\hline Snorre A & $\mathrm{PAH} 4+$ ring & 5.02E-05 & 5.02E-05 & $5.02 \mathrm{E}-05$ \\
\hline Snorre A & Phenol C0-C3 & $4.60 \mathrm{E}-02$ & $4.60 \mathrm{E}-02$ & $4.60 \mathrm{E}-02$ \\
\hline Snorre A & Phenol C4-C5 & 6.99E-03 & 6.99E-03 & 6.99E-03 \\
\hline Snorre A & Phenol C6+ & $1.18 \mathrm{E}-03$ & $1.18 \mathrm{E}-03$ & $1.18 \mathrm{E}-03$ \\
\hline Snorre A & Prod. chems & $1.57 \mathrm{E}+01$ & $1.78 \mathrm{E}+01$ & $2.23 \mathrm{E}+01$ \\
\hline Snorre A & Zinc & $5.62 E-04$ & $5.62 \mathrm{E}-04$ & $5.62 \mathrm{E}-04$ \\
\hline Snorre B & Aliphatic HCs & $1.09 \mathrm{E}+00$ & $1.09 \mathrm{E}+00$ & $1.09 \mathrm{E}+00$ \\
\hline Snorre B & Arsenic & $1.25 \mathrm{E}-01$ & $1.25 \mathrm{E}-01$ & $1.25 \mathrm{E}-01$ \\
\hline Snorre B & BTEX & $7.86 \mathrm{E}-01$ & $7.86 \mathrm{E}-01$ & $7.86 \mathrm{E}-01$ \\
\hline Snorre B & Cadmium & $9.13 \mathrm{E}-05$ & $9.13 \mathrm{E}-05$ & $9.13 \mathrm{E}-05$ \\
\hline Snorre B & Chromium & $1.24 \mathrm{E}-04$ & $1.24 \mathrm{E}-04$ & $1.24 \mathrm{E}-04$ \\
\hline Snorre B & Copper & $1.19 \mathrm{E}-02$ & $1.19 \mathrm{E}-02$ & $1.19 \mathrm{E}-02$ \\
\hline Snorre B & Lead & $1.22 \mathrm{E}-02$ & $1.22 \mathrm{E}-02$ & $1.22 \mathrm{E}-02$ \\
\hline Snorre B & Mercury & $8.30 \mathrm{E}-04$ & $8.30 \mathrm{E}-04$ & $8.30 \mathrm{E}-04$ \\
\hline Snorre B & Naphthalenes & $5.02 \mathrm{E}-02$ & $5.02 \mathrm{E}-02$ & $5.02 \mathrm{E}-02$ \\
\hline Snorre B & Nickel & $1.06 \mathrm{E}-04$ & $1.06 \mathrm{E}-04$ & $1.06 \mathrm{E}-04$ \\
\hline Snorre B & Organic acid & $3.43 \mathrm{E}+00$ & $3.43 E+00$ & $3.43 \mathrm{E}+00$ \\
\hline Snorre B & PAH 2-3 ring & $6.70 \mathrm{E}-02$ & $6.70 \mathrm{E}-02$ & $6.70 \mathrm{E}-02$ \\
\hline Snorre B & $\mathrm{PAH} 4+$ ring & $9.62 \mathrm{E}-05$ & $9.62 \mathrm{E}-05$ & $9.62 \mathrm{E}-05$ \\
\hline Snorre B & Phenol $\mathrm{CO}-\mathrm{C} 3$ & 7.02E-02 & 7.02E-02 & 7.02E-02 \\
\hline
\end{tabular}




\begin{tabular}{|c|c|c|c|c|}
\hline Platform / Discharge & EIF group & Toxic Unit Option 1 & Toxic Unit Option 2 & Toxic Unit Option 3 \\
\hline Snorre B & Phenol C4-C5 & $1.33 \mathrm{E}-02$ & $1.33 \mathrm{E}-02$ & $1.33 \mathrm{E}-02$ \\
\hline Snorre B & Phenol C6+ & 1.87E-03 & $1.87 \mathrm{E}-03$ & 1.87E-03 \\
\hline Snorre B & Prod. chems & $1.10 \mathrm{E}+00$ & 4.17E-01 & 3.33E-01 \\
\hline Snorre B & Zinc & $3.50 \mathrm{E}-03$ & $3.50 \mathrm{E}-03$ & $3.50 \mathrm{E}-03$ \\
\hline Statfjord A & Aliphatic HCs & $1.36 \mathrm{E}+00$ & $1.36 \mathrm{E}+00$ & $1.36 \mathrm{E}+00$ \\
\hline Statfjord A & Arsenic & $9.73 \mathrm{E}-05$ & $9.73 \mathrm{E}-05$ & 9.73E-05 \\
\hline Statfjord A & BTEX & $1.10 \mathrm{E}+00$ & $1.10 \mathrm{E}+00$ & $1.10 \mathrm{E}+00$ \\
\hline Statfjord A & Cadmium & $5.95 \mathrm{E}-06$ & 5.95E-06 & $5.95 \mathrm{E}-06$ \\
\hline Statfjord A & Chromium & $7.54 \mathrm{E}-05$ & 7.54E-05 & 7.54E-05 \\
\hline Statfjord A & Copper & $4.58 \mathrm{E}-04$ & $4.58 \mathrm{E}-04$ & $4.58 \mathrm{E}-04$ \\
\hline Statfjord A & Lead & $2.62 \mathrm{E}-04$ & $2.62 \mathrm{E}-04$ & $2.62 \mathrm{E}-04$ \\
\hline Statfjord A & Mercury & $6.71 \mathrm{E}-05$ & $6.71 \mathrm{E}-05$ & $6.71 \mathrm{E}-05$ \\
\hline Statfjord A & Naphthalenes & $3.23 E-02$ & $3.23 \mathrm{E}-02$ & $3.23 E-02$ \\
\hline Statfjord A & Nickel & $1.36 \mathrm{E}-04$ & $1.36 \mathrm{E}-04$ & $1.36 \mathrm{E}-04$ \\
\hline Statfjord A & Organic acid & $7.02 E+00$ & $7.02 \mathrm{E}+00$ & $7.02 \mathrm{E}+00$ \\
\hline Statfjord A & PAH 2-3 ring & 7.03E-02 & 7.03E-02 & 7.03E-02 \\
\hline Statfjord A & $\mathrm{PAH} 4+$ ring & $6.06 \mathrm{E}-05$ & $6.06 \mathrm{E}-05$ & $6.06 \mathrm{E}-05$ \\
\hline Statfjord A & Phenol $\mathrm{CO}-\mathrm{C} 3$ & $8.40 \mathrm{E}-02$ & $8.40 \mathrm{E}-02$ & $8.40 \mathrm{E}-02$ \\
\hline Statfjord A & Phenol C4-C5 & $2.32 \mathrm{E}-02$ & $2.32 \mathrm{E}-02$ & $2.32 \mathrm{E}-02$ \\
\hline Statfjord A & Phenol C6+ & $3.06 \mathrm{E}-03$ & $3.06 \mathrm{E}-03$ & $3.06 \mathrm{E}-03$ \\
\hline Statfjord A & Prod. chems & $3.12 \mathrm{E}+01$ & $1.83 \mathrm{E}+01$ & $3.19 \mathrm{E}+01$ \\
\hline Statfjord A & Zinc & $3.05 \mathrm{E}-03$ & $3.05 \mathrm{E}-03$ & $3.05 E-03$ \\
\hline Statfjord B & Aliphatic HCs & $2.27 E+00$ & $2.27 \mathrm{E}+00$ & $2.27 \mathrm{E}+00$ \\
\hline Statfjord B & Arsenic & $3.28 \mathrm{E}-04$ & $3.28 \mathrm{E}-04$ & $3.28 \mathrm{E}-04$ \\
\hline Statfjord B & BTEX & $1.28 \mathrm{E}+00$ & $1.28 \mathrm{E}+00$ & $1.28 \mathrm{E}+00$ \\
\hline Statfjord B & Cadmium & $1.98 \mathrm{E}-05$ & $1.98 \mathrm{E}-05$ & $1.98 \mathrm{E}-05$ \\
\hline Statfjord B & Chromium & $8.18 \mathrm{E}-05$ & $8.18 \mathrm{E}-05$ & $8.18 \mathrm{E}-05$ \\
\hline Statfjord B & Copper & $1.09 \mathrm{E}-03$ & $1.09 \mathrm{E}-03$ & $1.09 \mathrm{E}-03$ \\
\hline Statfjord B & Lead & $3.23 \mathrm{E}-04$ & $3.23 \mathrm{E}-04$ & $3.23 \mathrm{E}-04$ \\
\hline Statfjord B & Mercury & $1.80 \mathrm{E}-04$ & $1.80 \mathrm{E}-04$ & $1.80 \mathrm{E}-04$ \\
\hline Statfjord B & Naphthalenes & $3.86 \mathrm{E}-02$ & $3.86 \mathrm{E}-02$ & $3.86 \mathrm{E}-02$ \\
\hline Statfjord B & Nickel & $4.33 \mathrm{E}-05$ & $4.33 \mathrm{E}-05$ & $4.33 E-05$ \\
\hline Statfjord B & Organic acid & $6.37 E+00$ & $6.37 \mathrm{E}+00$ & $6.37 \mathrm{E}+00$ \\
\hline Statfjord B & PAH 2-3 ring & $1.16 \mathrm{E}-01$ & $1.16 \mathrm{E}-01$ & $1.16 \mathrm{E}-01$ \\
\hline Statfjord B & PAH 4+ ring & $1.86 \mathrm{E}-04$ & $1.86 \mathrm{E}-04$ & $1.86 \mathrm{E}-04$ \\
\hline Statfjord B & Phenol $\mathrm{CO}-\mathrm{C} 3$ & $9.76 \mathrm{E}-02$ & $9.76 \mathrm{E}-02$ & $9.76 \mathrm{E}-02$ \\
\hline Statfjord B & Phenol C4-C5 & $1.22 \mathrm{E}-02$ & $1.22 \mathrm{E}-02$ & $1.22 \mathrm{E}-02$ \\
\hline Statfjord B & Phenol C6+ & $2.10 \mathrm{E}-03$ & $2.10 \mathrm{E}-03$ & $2.10 \mathrm{E}-03$ \\
\hline Statfjord B & Prod. chems & $2.80 E+01$ & $3.13 E+01$ & $3.25 \mathrm{E}+01$ \\
\hline Statfjord B & Zinc & $5.17 \mathrm{E}-03$ & $5.17 \mathrm{E}-03$ & $5.17 \mathrm{E}-03$ \\
\hline Statfjord C & Aliphatic HCs & $1.66 \mathrm{E}+00$ & $1.66 \mathrm{E}+00$ & $1.66 \mathrm{E}+00$ \\
\hline Statfjord C & Arsenic & $2.30 \mathrm{E}-04$ & $2.30 \mathrm{E}-04$ & 2.30E-04 \\
\hline Statfjord C & BTEX & 7.01E-01 & 7.01E-01 & 7.01E-01 \\
\hline Statfjord C & Cadmium & $1.19 \mathrm{E}-05$ & 1.19E-05 & $1.19 \mathrm{E}-05$ \\
\hline Statfjord C & Chromium & $1.92 \mathrm{E}-04$ & $1.92 \mathrm{E}-04$ & $1.92 \mathrm{E}-04$ \\
\hline Statfjord C & Copper & $5.20 \mathrm{E}-04$ & $5.20 \mathrm{E}-04$ & $5.20 \mathrm{E}-04$ \\
\hline Statfjord C & Lead & $3.82 \mathrm{E}-04$ & $3.82 \mathrm{E}-04$ & $3.82 \mathrm{E}-04$ \\
\hline Statfjord C & Mercury & $4.22 \mathrm{E}-04$ & $4.22 \mathrm{E}-04$ & $4.22 \mathrm{E}-04$ \\
\hline Statfjord C & Naphthalenes & $3.45 \mathrm{E}-02$ & $3.45 \mathrm{E}-02$ & $3.45 \mathrm{E}-02$ \\
\hline Statfjord C & Nickel & $1.21 \mathrm{E}-04$ & $1.21 \mathrm{E}-04$ & $1.21 \mathrm{E}-04$ \\
\hline Statfjord C & Organic acid & $1.11 \mathrm{E}+01$ & $1.11 \mathrm{E}+01$ & $1.11 \mathrm{E}+01$ \\
\hline Statfjord C & PAH 2-3 ring & $1.05 \mathrm{E}-01$ & $1.05 \mathrm{E}-01$ & $1.05 \mathrm{E}-01$ \\
\hline Statfjord C & $\mathrm{PAH} 4+$ ring & $1.60 \mathrm{E}-04$ & $1.60 \mathrm{E}-04$ & $1.60 \mathrm{E}-04$ \\
\hline Statfjord C & Phenol $\mathrm{CO}-\mathrm{C} 3$ & $1.32 \mathrm{E}-01$ & $1.32 \mathrm{E}-01$ & $1.32 \mathrm{E}-01$ \\
\hline Statfjord C & Phenol C4-C5 & $1.89 \mathrm{E}-02$ & $1.89 \mathrm{E}-02$ & $1.89 \mathrm{E}-02$ \\
\hline Statfjord C & Phenol C6+ & $3.32 \mathrm{E}-03$ & $3.32 \mathrm{E}-03$ & $3.32 \mathrm{E}-03$ \\
\hline Statfjord C & Prod. chems & $4.54 \mathrm{E}+01$ & $4.82 E+01$ & $3.67 E+01$ \\
\hline Statfjord C & Zinc & $3.41 \mathrm{E}-03$ & $3.41 \mathrm{E}-03$ & $3.41 \mathrm{E}-03$ \\
\hline Troll B & Aliphatic HCs & $3.19 E+00$ & $3.19 \mathrm{E}+00$ & $3.19 \mathrm{E}+00$ \\
\hline Troll B & Arsenic & 4.92E-05 & $4.92 \mathrm{E}-05$ & $4.92 E-05$ \\
\hline Troll B & BTEX & $2.37 \mathrm{E}-01$ & 2.37E-01 & $2.37 \mathrm{E}-01$ \\
\hline Troll B & Cadmium & 7.94E-06 & 7.94E-06 & 7.94E-06 \\
\hline Troll B & Chromium & $6.58 \mathrm{E}-05$ & $6.58 \mathrm{E}-05$ & $6.58 \mathrm{E}-05$ \\
\hline Troll B & Copper & $1.71 \mathrm{E}-03$ & $1.71 \mathrm{E}-03$ & $1.71 \mathrm{E}-03$ \\
\hline Troll B & Lead & $5.73 \mathrm{E}-04$ & $5.73 \mathrm{E}-04$ & $5.73 E-04$ \\
\hline Troll B & Mercury & $6.71 \mathrm{E}-05$ & $6.71 \mathrm{E}-05$ & $6.71 E-05$ \\
\hline Troll B & Naphthalenes & $4.36 \mathrm{E}-02$ & $4.36 \mathrm{E}-02$ & $4.36 \mathrm{E}-02$ \\
\hline Troll B & Nickel & $4.00 \mathrm{E}-04$ & $4.00 \mathrm{E}-04$ & $4.00 \mathrm{E}-04$ \\
\hline Troll B & Organic acid & $4.58 \mathrm{E}-01$ & $4.58 \mathrm{E}-01$ & $4.58 \mathrm{E}-01$ \\
\hline Troll B & $\mathrm{PAH} 2-3$ ring & $1.10 \mathrm{E}-01$ & $1.10 \mathrm{E}-01$ & $1.10 \mathrm{E}-01$ \\
\hline Troll B & $\mathrm{PAH} 4+$ ring & $3.16 \mathrm{E}-04$ & $3.16 \mathrm{E}-04$ & $3.16 \mathrm{E}-04$ \\
\hline Troll B & Phenol $\mathrm{CO}-\mathrm{C} 3$ & $7.35 \mathrm{E}-03$ & 7.35E-03 & $7.35 \mathrm{E}-03$ \\
\hline Troll B & Phenol C4-C5 & $1.10 \mathrm{E}-02$ & $1.10 \mathrm{E}-02$ & $1.10 \mathrm{E}-02$ \\
\hline Troll B & Phenol C6+ & $5.61 \mathrm{E}-03$ & $5.61 \mathrm{E}-03$ & $5.61 E-03$ \\
\hline Troll B & Prod. chems & $3.18 \mathrm{E}-02$ & $3.11 \mathrm{E}-01$ & $1.51 \mathrm{E}-01$ \\
\hline Troll B & Zinc & $6.07 E-04$ & 6.07E-04 & $6.07 E-04$ \\
\hline Troll C & Aliphatic HCs & $2.77 E+00$ & $2.77 E+00$ & $2.77 \mathrm{E}+00$ \\
\hline Troll C & Arsenic & $3.05 \mathrm{E}-05$ & $3.05 \mathrm{E}-05$ & $3.05 \mathrm{E}-05$ \\
\hline Troll C & BTEX & $1.82 \mathrm{E}-01$ & $1.82 \mathrm{E}-01$ & $1.82 \mathrm{E}-01$ \\
\hline Troll C & Cadmium & 5.95E-06 & 5.95E-06 & $5.95 \mathrm{E}-06$ \\
\hline Troll C & Chromium & $3.80 \mathrm{E}-05$ & $3.80 \mathrm{E}-05$ & $3.80 \mathrm{E}-05$ \\
\hline Troll C & Copper & $7.35 \mathrm{E}-04$ & $7.35 \mathrm{E}-04$ & $7.35 E-04$ \\
\hline
\end{tabular}




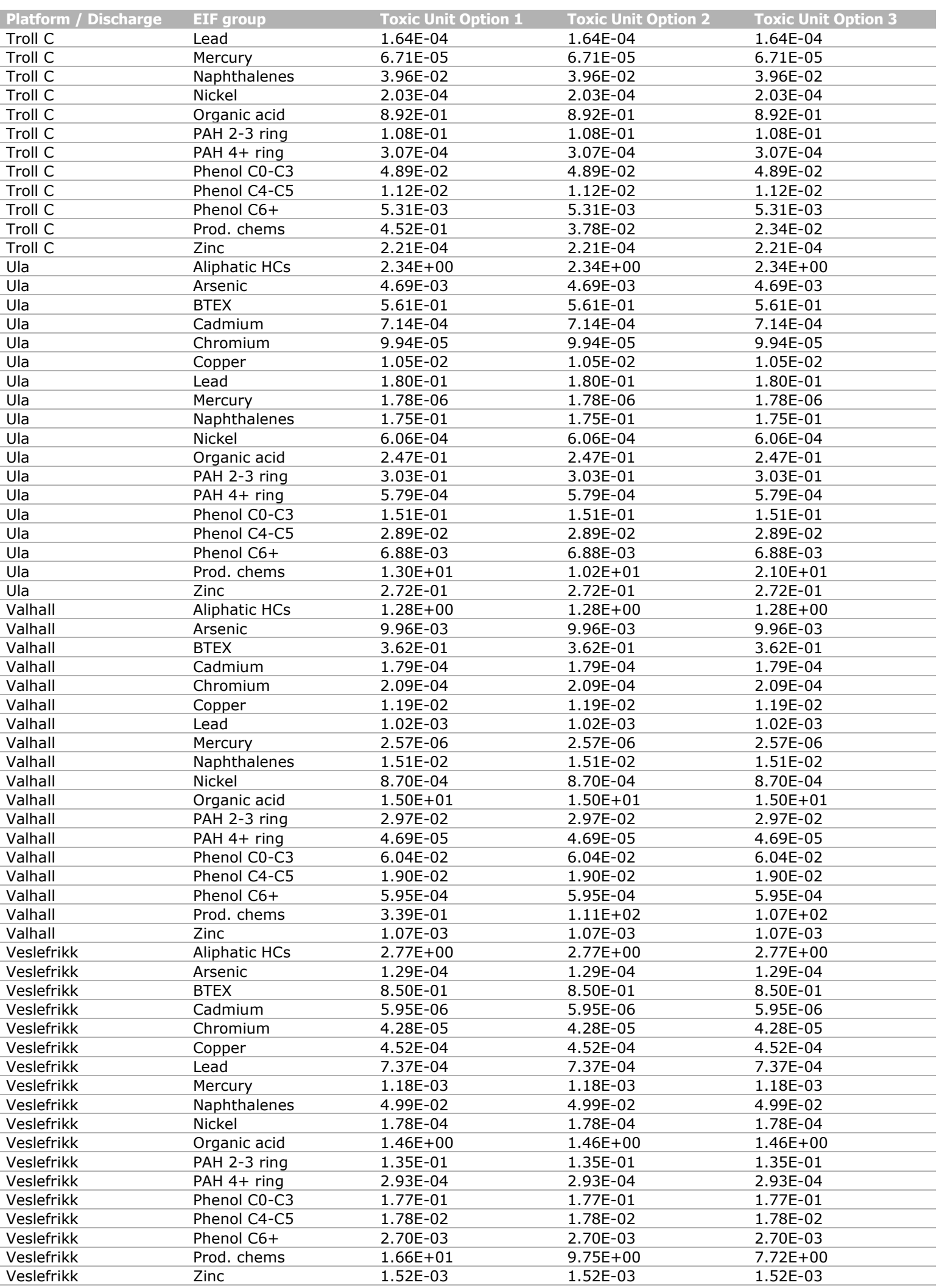




\section{Annex 6 Whole effluent toxicity tests that failed acceptance criteria}

Table 6.1

Per effluent and test species the number of toxicity tests for which one or more acceptance criteria are not met.

\begin{tabular}{|c|c|c|c|c|}
\hline Effluent / Platform & Acartia tonsa & $\begin{array}{l}\text { Skeletonema } \\
\text { costatum }\end{array}$ & Vibrio fischeri & Total \\
\hline \multicolumn{5}{|l|}{ Alvheim } \\
\hline Brage & 1 & & & 1 \\
\hline \multicolumn{5}{|l|}{ Draugen } \\
\hline Ekofisk M & 1 & 1 & & 2 \\
\hline \multicolumn{5}{|l|}{ Grane } \\
\hline Gullfaks A & 1 & & & 1 \\
\hline Gullfaks B & & 1 & 1 & 2 \\
\hline Jotun & 1 & & & 1 \\
\hline Knarr & 1 & 1 & & 2 \\
\hline Norne & 1 & 1 & 1 & 3 \\
\hline Skarv & & 1 & & 1 \\
\hline Snorre A & 1 & 1 & & 2 \\
\hline Snorre B & 1 & 1 & & 2 \\
\hline Statfjord A & 1 & 1 & 1 & 3 \\
\hline Statfjord B & 1 & 1 & & 2 \\
\hline Veslefrikk & 1 & 1 & & 2 \\
\hline Sum & 14 & 15 & 5 & 34 \\
\hline
\end{tabular}


Table 6.2

Per effluent and test species the number of toxicity tests for which one or more acceptance criteria are not met and where this failure could have affected the test result, as specified by the executing laboratory.

\begin{tabular}{|c|c|c|c|c|}
\hline Effluent / Platform & Acartia tonsa & $\begin{array}{l}\text { Skeletonema } \\
\text { costatum }\end{array}$ & Vibrio fischeri & Total \\
\hline \multicolumn{5}{|l|}{ Alvheim } \\
\hline Balder & & & 1 & 1 \\
\hline \multicolumn{5}{|l|}{ Brage } \\
\hline \multicolumn{5}{|l|}{ Draugen } \\
\hline Ekofisk J & & 1 & & 1 \\
\hline Ekofisk M & 1 & 1 & & 2 \\
\hline \multicolumn{5}{|l|}{ Grane } \\
\hline Gullfaks A & 1 & & & 1 \\
\hline Gullfaks B & & & 1 & 1 \\
\hline Gullfaks C & & & 1 & 1 \\
\hline \multicolumn{5}{|l|}{ Heidrun } \\
\hline Jotun & 1 & & & 1 \\
\hline Knarr & 1 & 1 & & 2 \\
\hline Norne & 1 & & 1 & 2 \\
\hline Skarv & & 1 & & 1 \\
\hline \multicolumn{5}{|l|}{ Snorre A } \\
\hline Snorre B & 1 & & & 1 \\
\hline Statfjord A & & & 1 & 1 \\
\hline Statfjord B & & 1 & & 1 \\
\hline Statfjord C & & 1 & & 1 \\
\hline \multicolumn{5}{|l|}{ Troll B } \\
\hline \multicolumn{5}{|l|}{ Troll C } \\
\hline Ula & & 1 & & 1 \\
\hline Valhall & & 1 & & 1 \\
\hline Veslefrikk & & 1 & & 1 \\
\hline Sum & 6 & 9 & 5 & 20 \\
\hline
\end{tabular}




\section{Annex $7 \quad$ Specific selection criteria applied to ecotoxicological data}

\section{Table 7.1}

Specific selection criteria applied to toxicity data for each EIF substance group (plus organic acids and the PLONOR production chemicals MEG and methanol) and species group (crustacea and algae) after the generic selection steps described in the main text. FW = freshwater; $S W=$ saltwater.

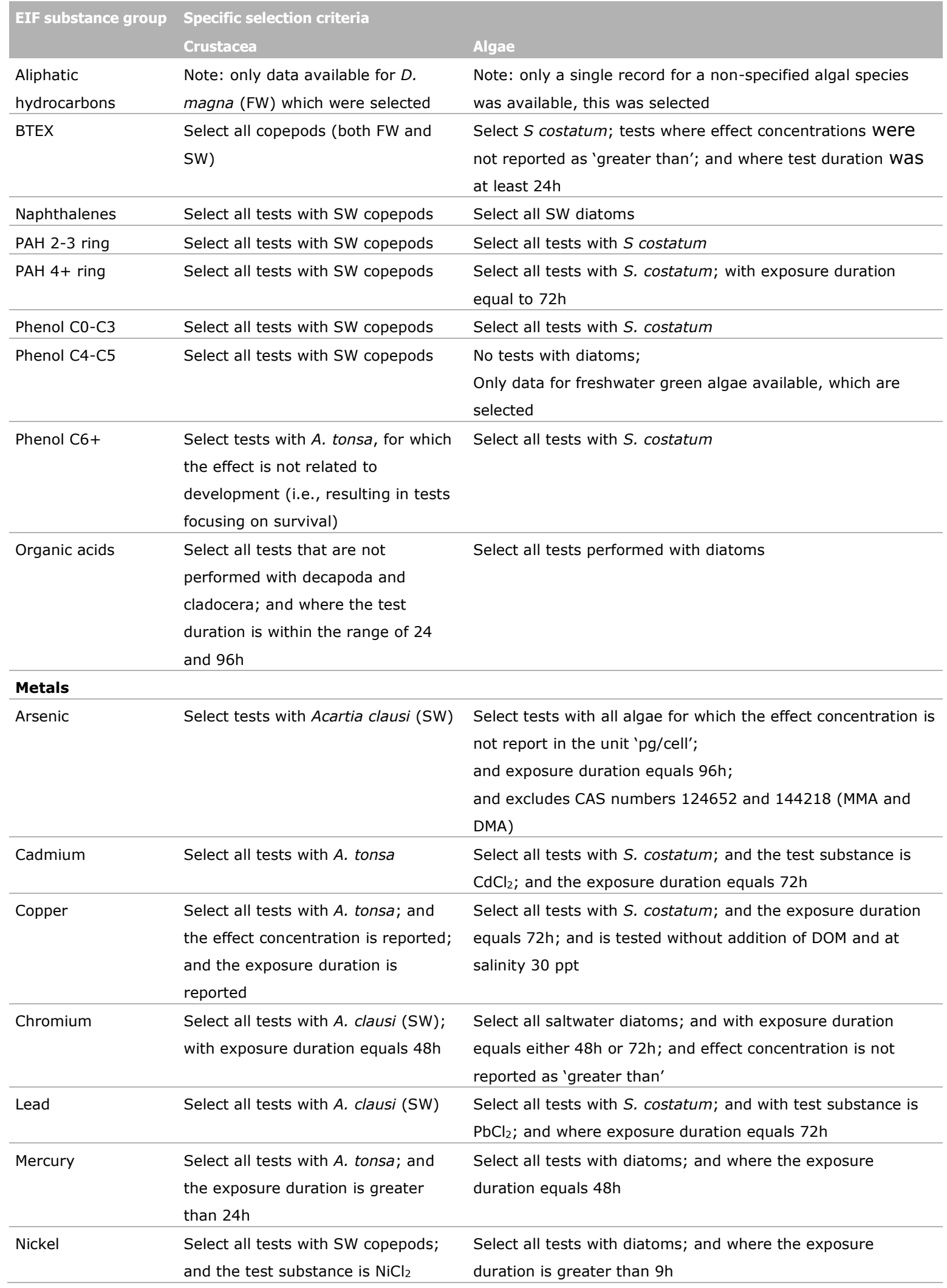


Select all tests with $S$. costatum; and where the test and the test substance is $\mathrm{ZnCl}_{2}$ substance is $\mathrm{ZnCl}_{2}$; and the exposure duration equals $72 \mathrm{~h}$

\section{PLONORs}

Monoethylene glycol Note: no data available for copepods; all available crustacean data was selected

Select all SW tests with Harpacticoida (similar sized crustacea)
Note: no data available from the EPA ECOTOX database. Data from https://toxnet.nlm.nih.gov/cgibin/sis/search/a?dbs+hsdb:@term+@DOCNO+174 is used. Reliability is unknown. 


\section{Annex 8 Comparison of PAH toxicity with data from other sources}

In the present study ecotoxicity data from the ECOTOX and EAT ECETOC databases were used. For PAHs a brief comparison was made with toxicity reported in other sources.

\section{Table 8.1}

A brief comparison of PAH toxicity reported by Verbruggen (2012) and Loibner et al. (2004), and the $50 \%$ effect concentrations used in the present study. Ranges show the EC50 values from these sources for (not specifically targeted) marine species, or freshwater species (labelled with footnote) if no marine data is available. It is indicated whether the values used in the present study are in the same range, higher or lower the other values.

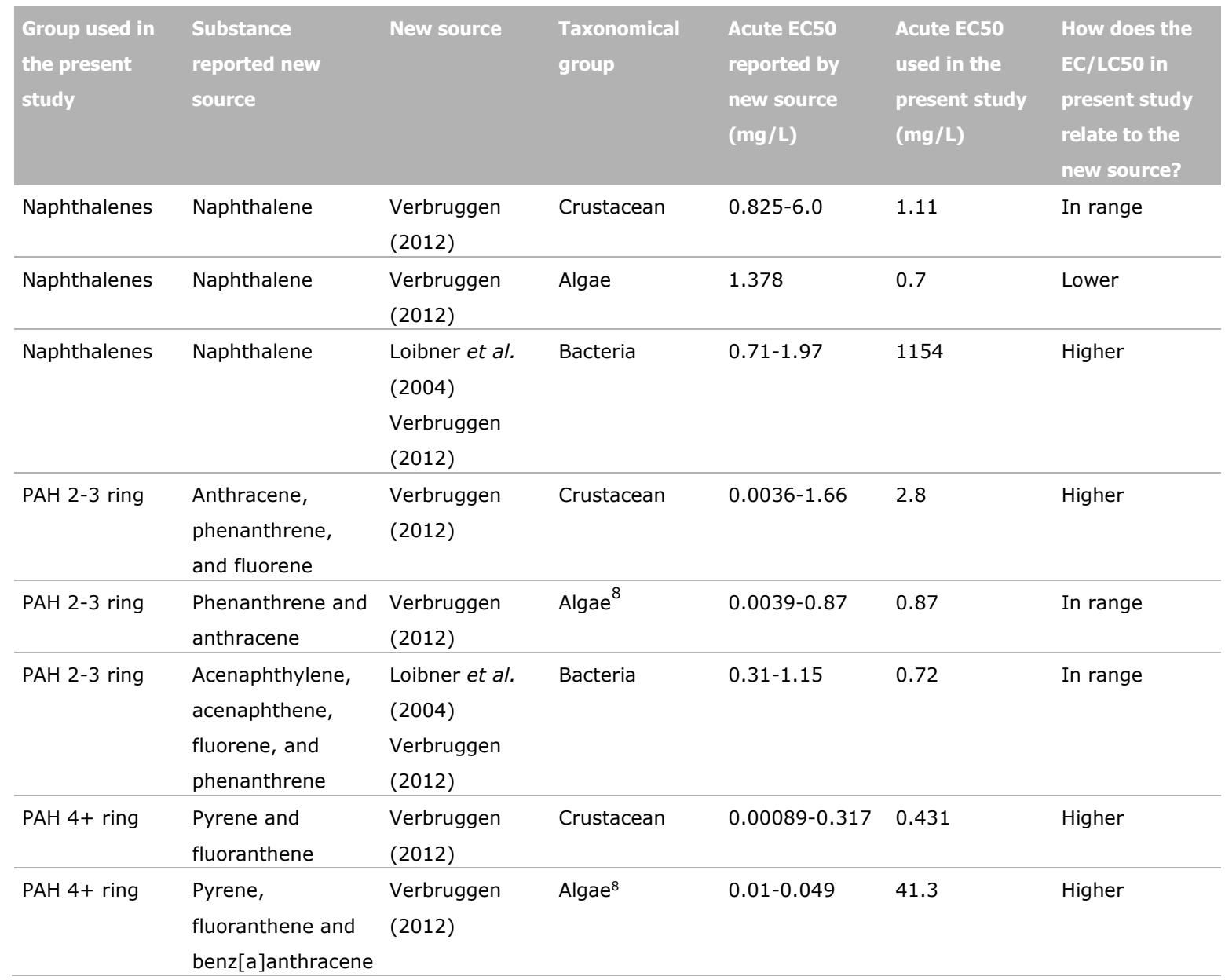

\footnotetext{
${ }^{8}$ Contains freshwater data
} 


\section{Annex 9 Principal Component Analyses}

Plots below show the results of the principal component analyses for each of the options for including added production chemicals (based on daily estimates (option 1); monthly estimates (option 2); and yearly estimates (option 3 )), show in the columns. Only the first three (most significant) principal components are shown in rows. The value on the $x$-axis is the rotation with respect to the principal component axis. High (both positive and negative) rotations indicate that these substance groups are important for that particular principal component. The substance groups are ranked from most important (top) to least important (bottom). As you would expect, the first (most significant; PC1) component is relatively robust and is very similar for each of the options. This is not so much the case for the second and third principal component (PC2 and PC3).

Option 1 (daily estimates)

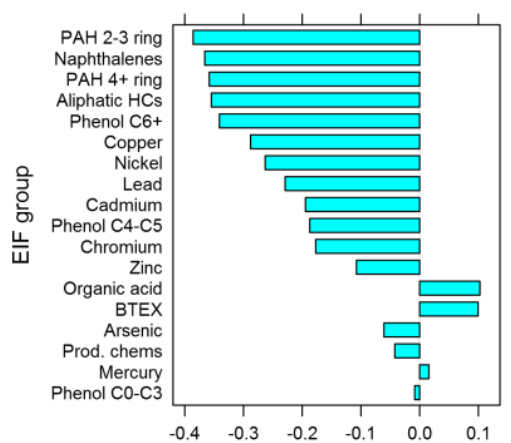

Option 1 (daily estimates)

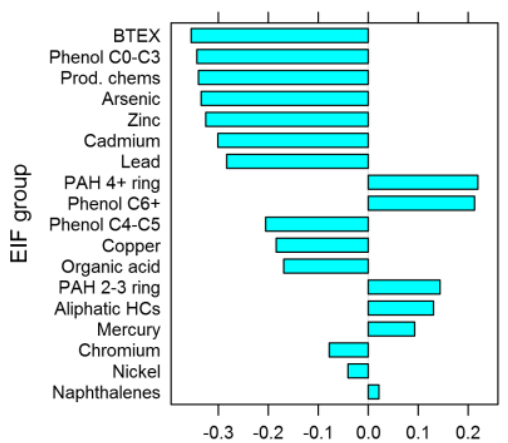

Option 1 (daily estimates)

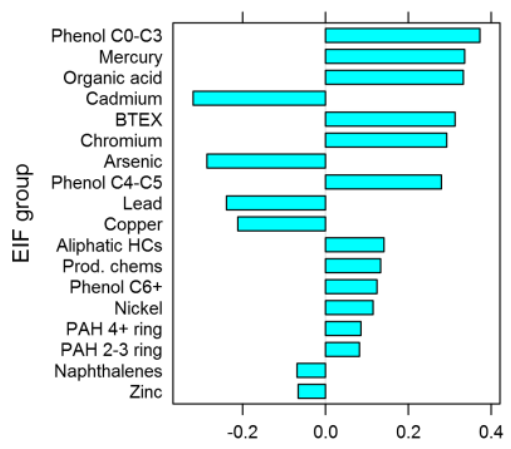

\section{Principal component 1}

Option 2 (monthly estimates)

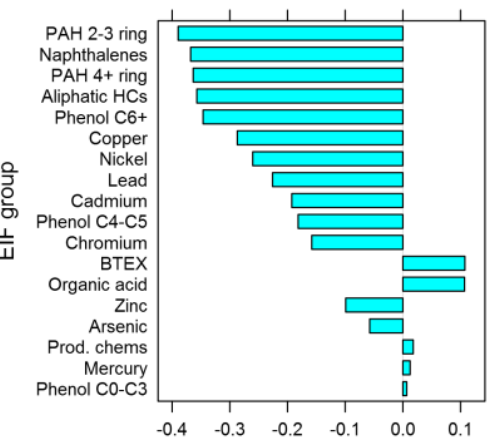

Principal component 2

Option 2 (monthly estimates)

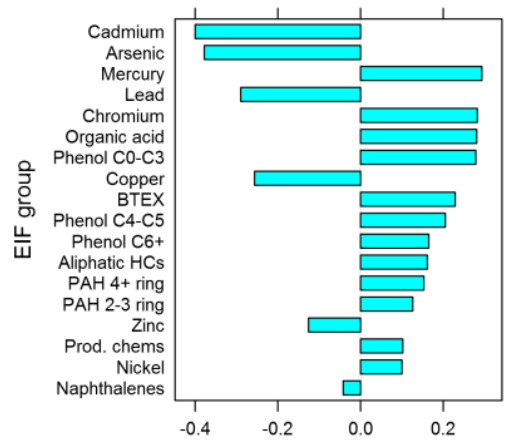

Principal component $\mathbf{3}$

Option 2 (monthly estimates)

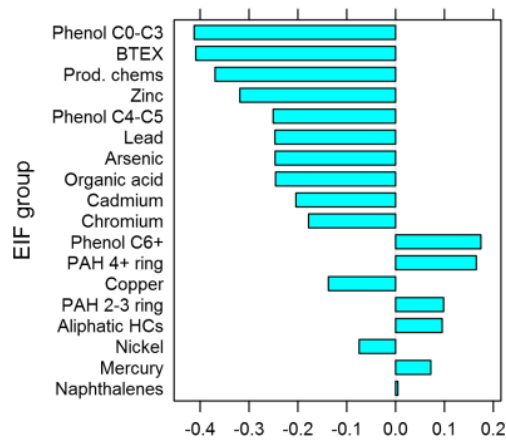

Option 3 (yearly estimates)

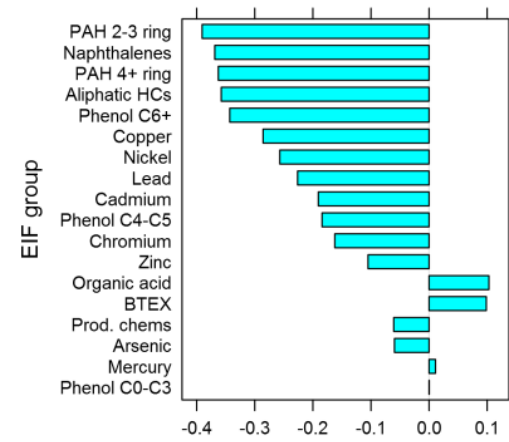

Option 3 (yearly estimates)

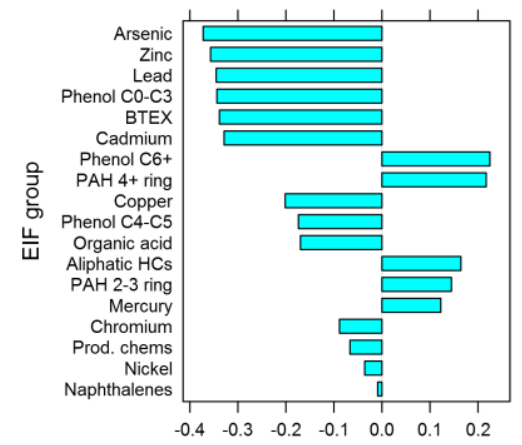

Option 3 (yearly estimates)

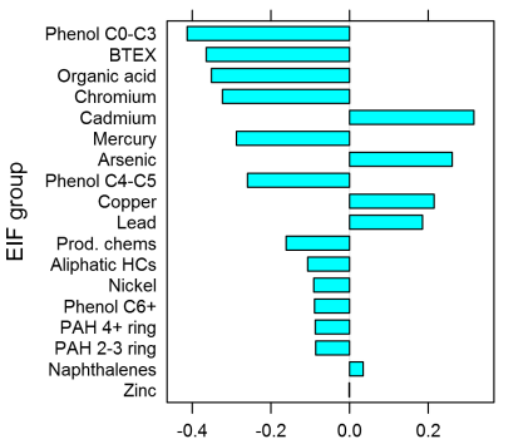




\section{Annex 10 Additional scatter plots}

The scatter plots below are identical to those in Figure 11 in the main text. Error bars are omitted here, and each platform is colour coded, showing the number of WET tests that failed its acceptance criteria to such an extent that it could have affected the test outcome.

\section{Option 1}

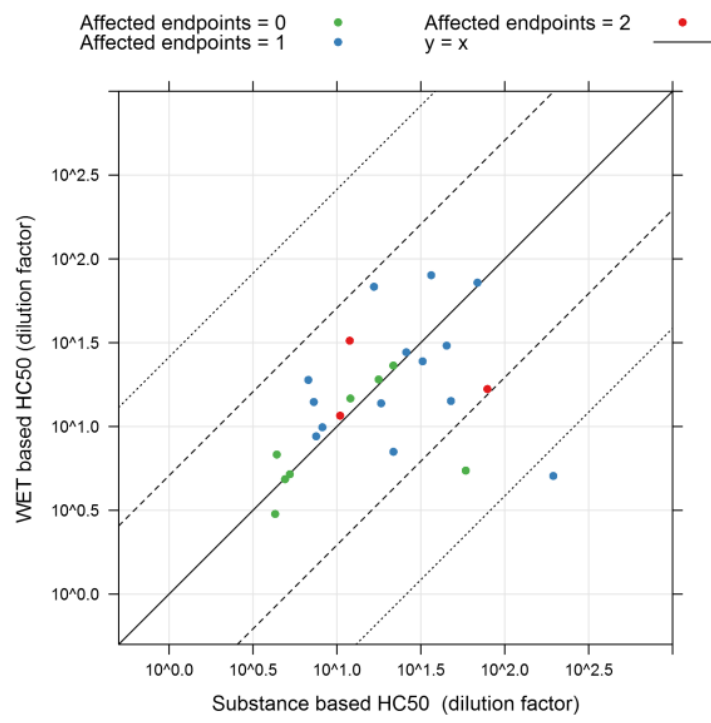

Option 3

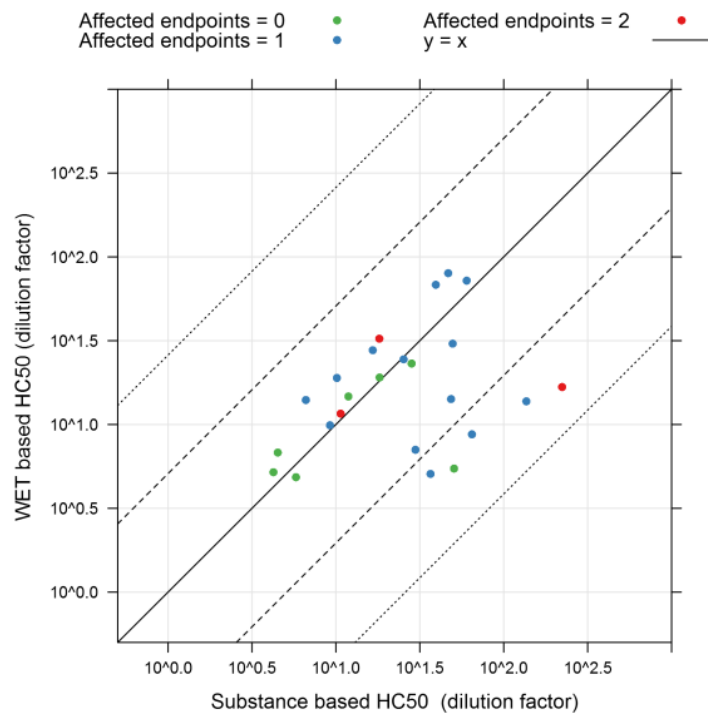

\section{Option 2}
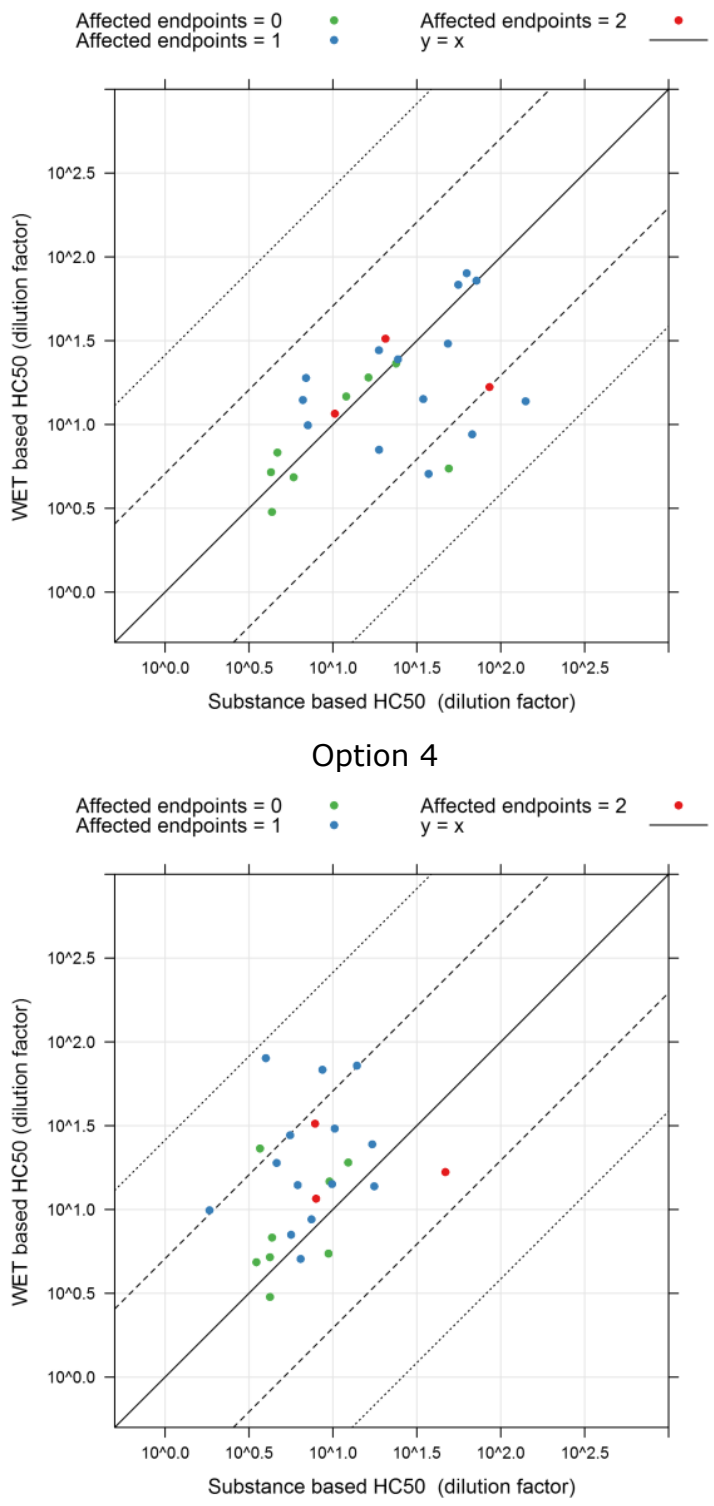
The scatter plots below are identical to those in Figure 11 in the main text. Error bars are omitted here, and each platform is colour coded, showing EIF substance group that dominates the hazard.

\section{Option 1}

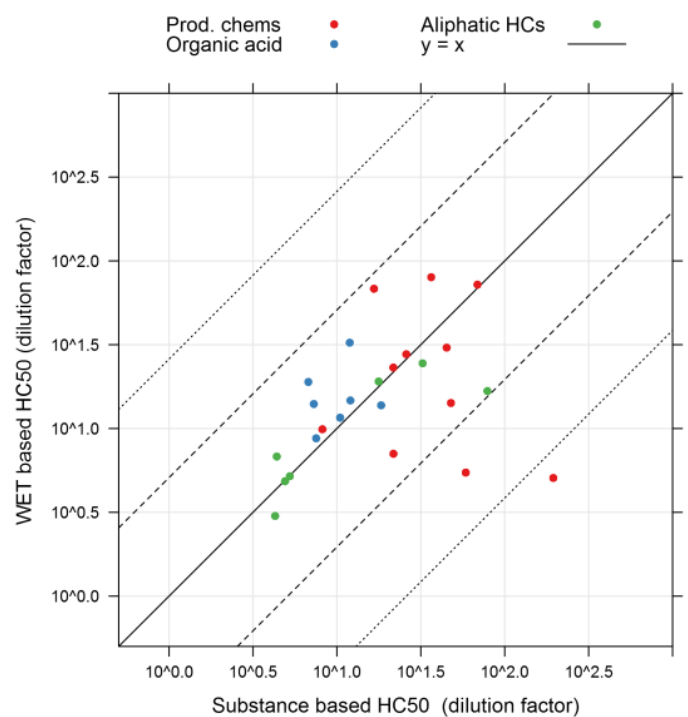

Option 3

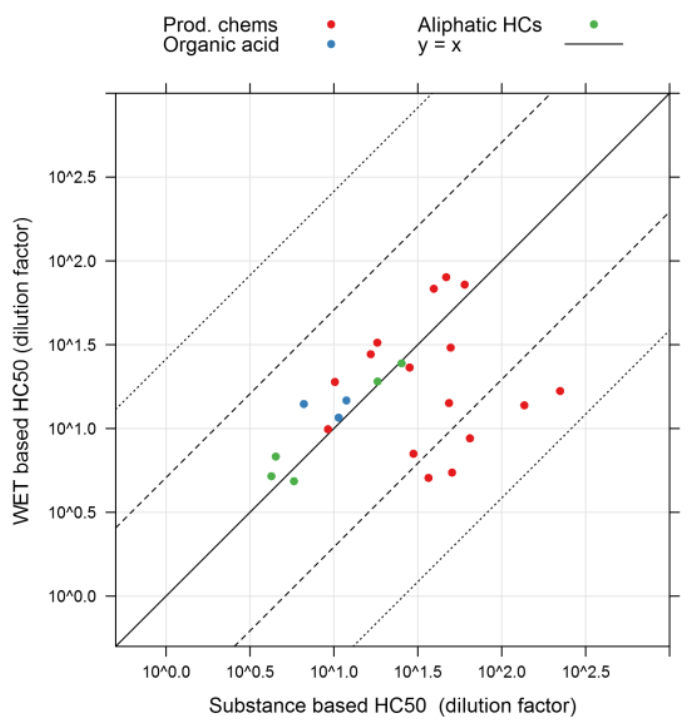

Option 2

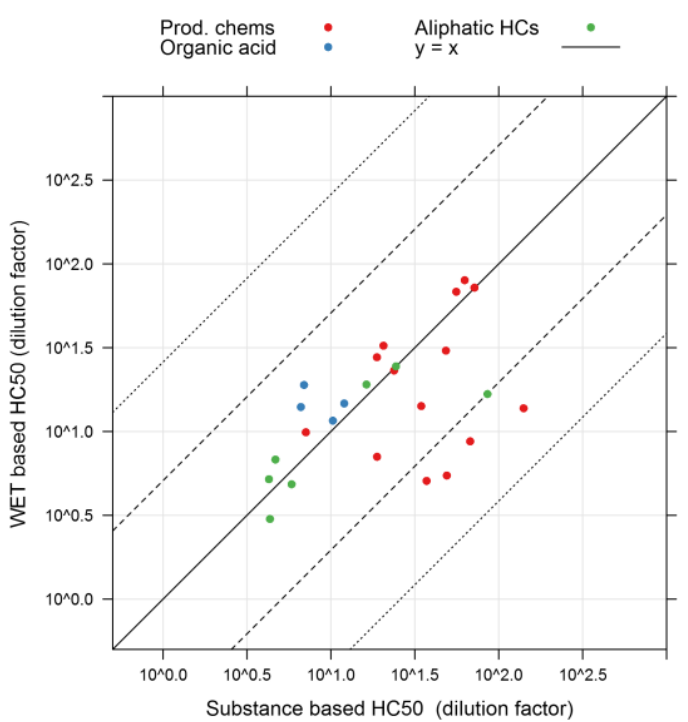


Wageningen Marine Research

T +31 (0)317480900

E marine-research@wur.nl

www.imares.eu/marine-research

Visitors' address

- Ankerpark 271781 AG Den Helder

- Korringaweg 7, 4401 NT Yerseke

- Haringkade 1, 1976 CP IJmuiden
Wageningen Marine Research is the Netherlands research institute established to provide the scientific support that is essential for developing policies and innovation in respect of the marine environment, fishery activities, aquaculture and the maritime sector.

\section{Wageningen University \& Research:}

is specialised in the domain of healthy food and living environment.

\section{The Wageningen Marine Research vision}

'To explore the potential of marine nature to improve the quality of life'

\section{The Wageningen Marine Research mission}

- To conduct research with the aim of acquiring knowledge and offering advice on the sustainable management and use of marine and coastal areas.

- Wageningen Marine Research is an independent, leading scientific research institute

Wageningen Marine Research is part of the international knowledge organisation Wageningen UR (University \& Research centre). Within Wageningen UR, nine specialised research institutes of the Stichting Wageningen Research Foundation have joined forces with Wageningen University to help answer the most important questions in the domain of healthy food and living environment. 